\title{
Systematic studies in the eucalypts. 9. A review of series Sociales (Eucalyptus subgenus Symphyomyrtus, Section Bisectaria, Myrtaceae)
}

\author{
L.A.S. Johnson ${ }^{\dagger} \&$ K.D. Hill
}

\begin{abstract}
Johnson, L.A.S., E Hill, K.D. (National Herbarium of New South Wales, Royal Botanic Gardens, Sydney, Australia 2000) 1999. Systematic studies in the eucalypts. 9. A review of series Sociales (Eucalyptus subgenus Symphyomyrtus, Section Bisectaria, Myrtaceae). Telopea 8(2): 165-218. A review of Eucalyptus series Sociales is presented, with a classification and enumeration of species recognised. A total of 30 species is recognised, 10 of them described here as new (E. delicata, E. dolichocera, E. hypolaena, E. intrasilvatica, E. luculenta, E. moderata, E. optima, E. sublucida E. ultima and E. vokesensis). New subspecies are recognised in E. oleosa (subsp. ampliata, corvina, cylindroidea, repleta, victima and wylieana) and E. transcontinentalis (subsp. semivestita). Revised circumscriptions are discussed for E. flocktoniae and E. grasbyi, and lectotypifications proposed for E. kochii, E. socialis and E. oleosa var. glauca (the latter as a synonym of E. transcontinentalis). Distributions of all taxa are mapped, and new and revised taxa are illustrated.
\end{abstract}

\section{Introduction}

The series Sociales is a predominantly Western Australian group, but with several members extending into eastern Australia and comprising important components of the flora of the eastern 'Mallee Lands'. The group is taxonomically complex, with a large number of species recognised in recent years. Some of these have already been described by ourselves and other workers, and additional new taxa are described here. An enumeration of all species that we recognise in this group is given below, however, complete descriptions are provided only for new taxa or taxa with substantially changed circumscriptions. Several of these taxa are treated as undescribed species or subspecies identified with alphabetic codes in the field guide to south-western taxa by Brooker and Kleinig (1990). The new taxa discussed both here and by Brooker and Kleinig were delineated by us during a comprehensive revisionary study of the eucalypts, and were freely discussed with Ian Brooker in order to allow the treatment in Brooker and Kleinig. Where appropriate, the alphabetic codes used by Brooker and Kleinig are given below in the discussion of the individual species.

Names of sections, series and subseries used by us are intentionally published in a system devised by Pryor and Johnson (1971) and external to the International Code of Botanical Nomenclature, as used and explained in previous publications in this series. Subseries names here differ from those used by Pryor and Johnson in ending with '-osae'. This is because '-ineae' (previously used) is a subtribal ending (Greuter 1994, Art. 19.3). Terminology used is as in previous publications in this series (see Hill \& Johnson 1995).

Rare or threatened species are allocated Conservation status codes according to the system of Briggs and Leigh (1996). 
We are acquainted with all the taxa in the field, except the desert species E. peeneri, E. vokesensis and E. wyolensis.

\section{Taxonomic history}

The names applied to series and subseries by earlier authors are cited below merely to indicate the way in which those authors grouped the species concerned. Nothing is implied about their standing, since we are using only the Pryor and Johnson extracodical system between genus and species.

The first species described in this series were E. oleosa F. Muell. ex Miq. and E. socialis F. Muell. ex Miq., described in 1856. The name E. turbinata was published by the same author at the same time, but has since proved conspecific with E. oleosa.

Bentham (1867) recognised only one taxon belonging to this series, placing E. socialis in the synonymy of E. oleosa. He also placed material of the taxon now known as E. transcontinentalis Maiden under both E. decurva F. Muell. and E. uncinata Turcz. var. rostrata Benth. He placed E. oleosa and E. decurva in series Normales subseries Inclusae, together with a diverse group of unrelated species.

Mueller (1879) placed E. socialis (again with a diverse group) in a series Strongylantherae. He did not list any other taxa of the group here under discussion.

Maiden (1903-1933, 6: 532) refined the anther-based classification, grouping the species he recognised in section Platyantherae, in the type subsection. These were placed with a slightly less diverse group of species than grouped by previous authors, but still including some distant elements. In his later seed classification (1903-1933, 7: 147), he placed E. oleosa and E. gillii in his series Foveolatae, a disparate group including a number of other unrelated taxa.

Blakely (1934) recognised 8 species in the group, placing all in section Platyantherae series Subulatae, again with a number of other variously related species.

Pryor and Johnson (1971) recognised a series Oleosae in section Bisectaria, including in it eight described and one undescribed species and foreshadowing the elevation of one variety to species rank.

Chippendale (1988) included 14 species in a group based on the Oleosae of Pryor and Johnson, adopting the series name Subulatae from Blakely and the series circumscription from Pryor and Johnson. Blakely, Pryor \& Johnson and Chippendale all placed the anomalous species E. cooperiana in this group, whereas we now regard this as an isolated species no closer to this group than to several others (see also Brooker \& Kleinig 1990).

Brooker and Kleinig (1990) recognised 20 species in the series Oleosae, 8 of them undescribed. These did not include E. cooperiana or E. brockwayi.

We consider the remaining taxa and their hitherto undescribed relatives to constitute a probable clade within the large section Bisectaria of the subgenus Symphyomyrtus. This clade can be treated as a series (series Sociales), with seven distinctive subclades that can be treated as subseries. (Table 1). We would include E. brockwayi in the Sociales as a derived monotypic subseries on the basis of the crowded, spirally arranged juvenile foliage shared with subseries Longicornosae. The strikingly distinctive fruits and bud characters of E. brockwayi are autapomorphic, and of no value in defining relationships. 
Table 1. A classification of series Sociales

Subseries Brockwayanosae

$$
\text { E. brockwayi }
$$

Subseries Longicornosae

$$
\begin{aligned}
& \text { E. longicornis } \\
& \text { E. oleosa } \\
& \text { subsp. repleta } \\
& \text { subsp. cylindroidea } \\
& \text { subsp. oleosa } \\
& \text { subsp. ampliata } \\
& \text { subsp. victima } \\
& \text { subsp. wylieana } \\
& \text { subsp. corvina }
\end{aligned}
$$

E. delicata

Subseries Grasbyanosae
E. grasbyi
E. eremicola
E. sublucida
E. peeneri
E. plenissima
E. kochii
E. horistes
E. ultima

Subseries Aspersosae

E. aspersa
Subseries Socialosae
E. socialis
E. yalatensis
E. gillii
E. eucentrica
E. vokesensis
E. wyolensis
E. yumbarrana
E. dolichocera

Subseries Transcontinentalosae

E. moderata

E. transcontinentalis

subsp. transcontinentalis subsp. semivestita
E. hypolaena
E. optima
E. neutra
E. luculenta

Subseries Flocktonianosae

E. flocktoniae subsp. flocktoniae subsp. hebes

E. urna

E. peninsularis

Interserial hybridogenous species

Series 'Falcatosociales'

E. intrasilvatica

\section{Section Bisectaria}

Bisectaria is the largest section in subgenus Symphyomyrtus, comprising about 270 taxa (species and subspecies). The vast majority are restricted to the Mediterranean climatic region of southwestern Western Australia, which is arguably the centre of origin and diversification for the group (although probably not possessing a 'Mediterranean' climate earlier in the history of the group). The deduced relationships of the taxa at the various levels lead strongly to the conclusion that the arid zone and eastern regions have been separately colonised on several occasions by members of different series, and several radiation and isolation events can be postulated (Hill 1989, 1990).

The section is characterised as follows: cotyledons deeply bisected, varied in size and shape; pith glands present or absent; bark glands absent; adult leaves amphistomatic (hypostomatic in E. dundasii); phyllotaxis disjunct, opposite or (exceptionally and 
secondarily) spiral; calyx calyptriform (apparently free in E. steedmanii), free from corolla, shedding early in bud development (persistent to anthesis in subseries Caesiosae); anthers versatile or adnate, highly varied in shape.

Prominent reticulation (i.e. veins of all grades raised above surrounding leaf surface) in early seedling leaves is probably a plesiomorphic character in Bisectaria. This feature occurs in a number of series, in generally unspecialised taxa within the various series. Examples are Loxophlebae, Prominentes, Sociales, Macrocarpae, and Orbifoliae. Reduncae and Desmondenses show prominence in only the main laterals, while Salubres and Annulatae show complete reduction in this feature.

Phylogenetic relationships of the series within Bisectaria remain to be clarified, and the section has not been shown to be unequivocally monophyletic. Subgroups herein treated as series are, however, generally clearly defined and for the most part possess clear synapomorphies supporting their monophyly. One such distinct group is the Sociales.

\section{Series Sociales}

The series is characterised as follows: pith glands absent; cotyledon lobes narrowlinear; juvenile leaves dull; adult leaves dull or glossy, amphistomatic; filaments variably flexed, usually mostly regularly inflexed with a few outer filaments erect; anthers globoid, \pm basifixed, versatile; connective gland large; cells divergent; style persistent, splitting and remaining attached to valves, although fragile and often broken off in fruit; disc depressed; seeds rounded, elliptical, semi-glossy, grey-brown, regularly very shallowly reticulate and weakly longitudinally striate; hilum ventral; chaff dimorphic, with linear and blocky forms, brown or red-brown.

Seven constituent subseries are recognised (Table 1), with diagnostic characters as below. Twenty-nine species are included, with an additional species thought to be of interserial hybridogenous origin and placed in a 'series of convenience' (see below). The name Sociales is used in preference to the previously used Oleosae since the use of the subseries termination -osae introduces some confusion as to ranking.

\section{Key to subseries and species}

1 Juvenile leaves ericoid

2 Juvenile leaves hairy; style tip not engaged in calyptra

Subseries Brockwayanosae (1. E. brockwayi)

2 Juvenile leaves glabrous; style tip engaged in a pit in calyptra

Subseries Longicornosae (species 2-4)

3 Trees

4 Fruits $6-9 \times 5-7 \mathrm{~mm}$

5 Calyptra up to $2 \times$ hypanthium

3. E. oleosa

5 Calyptra more than $2 \times$ hypanthium 2. E. longicornis

4 Fruits $4-5 \times 4-5 \mathrm{~mm}$ 4. E. delicata

3 Mallees

3. E. oleosa

1 Juvenile leaves not ericoid

6 Juvenile leaves not decurrent 
7 Buds rounded or acute, not rostrate; Adult leaves usually glossy or semiglossy

8 Juvenile leaves petiolate

9 Juvenile leaves disjunct after few nodes, shortly petiolate $(<5 \mathrm{~mm})$, linear to lanceolate Subseries Grasbyanosae (species 5-12)

10 Adult leaves highly glossy

11 Peduncles and pedicels long (7-23 $\mathrm{mm}$ and $4-10 \mathrm{~mm})$

5. E. grasbyi

11 Peduncles and pedicels short (4-11 $\mathrm{mm}$ and 2-5 $\mathrm{mm}$ )

6. E. eremicola

10 Adult leaves dull or semiglossy

12 Adult leaves semiglossy

13 Bark persistent at least on lower trunk

14 Adult leaves bluish 7 E. sublucida

14 Adult leaves green 10. E. horistes

13 Bark wholly smooth 9. E. ultima

12 Adult leaves dull

15 Calyptra $>2 \times$ hypanthium, sharp-pointed; leaves bluish

8. E. peeneri

15 Calyptra $<2 \times$ hypanthium, blunt; leaves green

16 Calyptra hemispherical; fruits urceolate ....

12. E. plenissima

16 Calyptra conical; fruits globular

11. E. kochii

9 Juvenile leaves persisting opposite for many nodes, long-petiolate ( $>6 \mathrm{~mm}$ ), ovate Series 'Falcatosociales' (31. E. intrasilvatica)

8 Juvenile leaves sessile, opposite for many nodes Subseries Aspersosae (13. E. aspersa)

7 Buds rostrate; adult leaves dull; Subseries Socialosae (species 14-21)

17 Adult leaves disjunct, petiolate

18 Twigs lacking a glaucous wax coating

19 Calyptra $<2 \times$ hypanthium

20 Buds and fruits small $(6-13 \times 3-4$ and $4-7 \times 4-7 \mathrm{~mm})$; flowers white to cream

21 Stems erect; bark persistent on up to $1 / 3$ of trunk

14. E. socialis

21 Stems sprawling and twisted; bark persistent on $>1 / 2$ of trunk

15. E. yalatensis

20 Buds and fruits medium to large (10-20 × 4-7 and 6-12 × 6-12 $\mathrm{mm})$; flowers yellow

22 Buds and fruits medium (10-17 × 4-5 and 6-9 × 6-9 mm) 
22 Buds and fruits large $(14-20 \times 5-8$ and $8-12 \times 8-12 \mathrm{~mm})$ 20. E. yumbarrana

19 Calyptra $>2.5 \times$ hypanthium

21. E. dolichocera

18 Twigs strongly glaucous with a wax coating

18. E. vokesensis

17 Adult leaves opposite, sessile (plant neotenous)

23 Leaves, buds and fruits large (9-15 × 4-6 and 6-9 × 6-10 mm)

19. E. wyolensis

23 Leaves, buds and fruits small $(7-12 \times 3-5$ and $4-6 \times 4-6 \mathrm{~mm})$

16. E. gillii

6 Juvenile leaves decurrent

24 Adult leaves not strongly glossy

Subseries Transcontinentalosae (species 22-27)

25 Trees

26 Buds and fruits small $(14-20 \times 5-7$ and 5-9 × 5-8 mm)

23. E. transcontinentalis

26 Buds and fruits large (14-22 × 6-8 and 8-10 × 9-12 mm)

27 Bark persistent on lower trunk

25. E. hypolaena

27 Bark wholly smooth

24. E. optima

25 Mallees

28 Buds and fruits not glaucous

22. E. moderata

28 Buds and fruits glaucous

29 Buds and fruits small (10-15 × 4-5 and 6-9 × 5-8 mm); fruits dull beneath wax covering

26. E. neutra

29 Buds and fruits large $(13-17 \times 5-7$ and $7-11 \times 6-10 \mathrm{~mm})$; fruits glossy beneath wax covering

27. E. luculenta

24 Adult leaves strongly glossy ....... Subseries Flocktonianosae (species 28-30)

30 Mallee; fruits ribbed or smooth

31 Fruits smooth

29. E. flocktoniae

31 Fruits ribbed

30. E. peninsularis

30 Tree; fruits strongly ribbed

28. E. urna

\section{Subseries Brockwayanosae}

Subseries defined as follows: juvenile leaves spirally arranged, crowded (sometimes opposite), becoming disjunct, minutely decurrent, with an indumentum of simple hairs arising from undifferentiated epidermis; adult leaves glossy; calyptra rounded; filaments variably flexed in bud, mostly regularly inflexed with a few outer filaments erect; most (not all) anthers appressed to disc; style short (not touching calyptra).

A monospecific subseries with a limited distribution in the southern Goldfields region of Western Australia. Relationships are discussed under taxonomic history above. 
1. Eucalyptus brockwayi C.A. Gardner, J. E Proc. Roy. Soc. Western Australia 27: 185 (1942).

Type: Western Australia: Coolgardie district, near Norseman, G.E. Brockway \& C.A. Gardner 5598, 15 Dec 1940 (holo PERTH).

Tree. Bark smooth. Juvenile leaves \pm sessile, hairy, spirally arranged. Adult leaves narrow-lanceolate, highly glossy, 8-12 cm long, 7-15 mm wide. Peduncles 4-11 mm long. Pedicels 1-2 mm long. Calyptra short (= hypanthium), rounded. Buds ovoid, small $(6-9 \times 3-4 \mathrm{~mm})$. Fruits urceolate, small $(5-6 \times 4-6 \mathrm{~mm})$ valves enclosed.

The single species in the subseries, with distinguishing characters as for the subseries.

Locally frequent but restricted to the area around Norseman (Fig 1), in tall closed woodlands on pale loamy calcareous soils.

Conservation status: although not under threat, this species is of limited distribution. A code of $2 \mathrm{R}$ is appropriate.

\section{Subseries Longicornosae}

Subseries defined as follows: juvenile phyllotaxis spiral, crowded (sometimes opposite), becoming disjunct; adult leaves glossy, amphistomatic; calyptra rounded to acute, not rostrate; filaments variably flexed in bud, with outer filaments erect and inner filaments regularly inflexed; style tip inserted into calyptra.

Three species are included in the subseries, one of them the widely distributed and highly complex E. oleosa. The subseries ranges from the Wheat Belt of Western Australia east to western Victoria and western New South Wales, with most of that range being occupied by variants of E. oleosa (herein recognised as subspecies, see below).

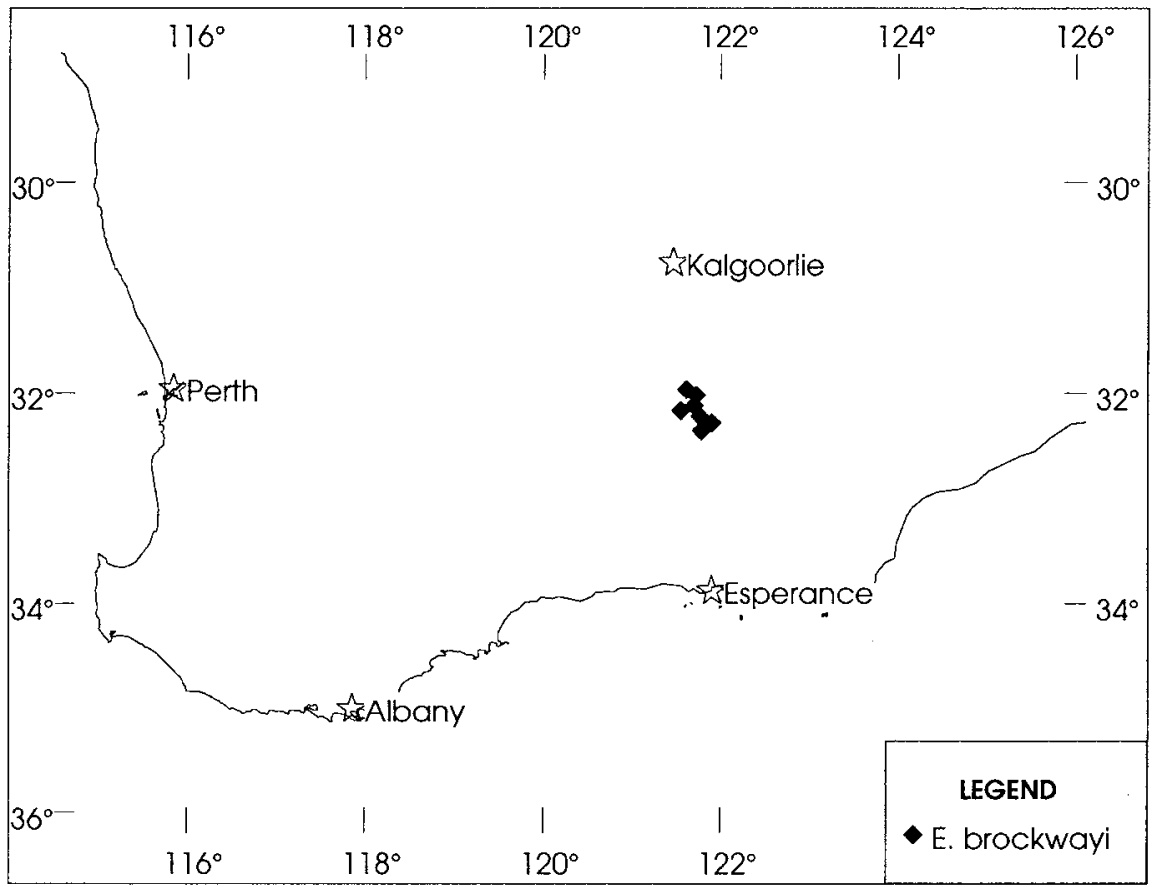

Fig. 1. Distribution of E. brockwayi. 
2. Eucalyptus longicornis (F. Muell.) F. Muell. ex Maiden, J. E Proc. Roy. Soc. New South Wales 2: 504 (1919).

Basionym: Eucalyptus oleosa F. Muell. var. longicornis F. Muell., Fragm. 11: 14 (1878); in syn.; For. Res. Western Australia, 12 (1879), fig. 13.

Type: Western Australia: Upper Swan River, F. Mueller, 1877 (holo MEL; iso NSW).

Tree. Bark persistent on trunk. Oil glands large, dense. Juvenile leaves \pm sessile. Pedicels and peduncles long, slender. Calyptra long (>1.5 $\times$ hypanthium), acute, regularly tapered. Buds conical, medium $(9-13 \times 4-5 \mathrm{~mm})$. Fruits subglobular, medium $(6-9 \times 5-7 \mathrm{~mm})$.

A frequent tree of loamy soils through much of the wheat belt, from Wongan Hills south to Broome Hill and east to Southern Cross (Fig. 2). A specimen at NSW from Norseman matches this taxon, although some distance from its normal range.

Intergrading populations with E. oleosa are abundant, and both these and western subspecies of E. oleosa have in the past been taken for E. longicornis.

Conservation status: not considered to be at risk.

3. Eucalyptus oleosa F. Muell. ex Miq., Ned. Kruidk. Arch. 4: 127 (1856).

Type: cited as 'Marble-range (Wilhelmi); Murray Scrub (Dr. Behr).' Burbidge (1947) stated that the Type (held in U, collector not specified) was a mixed collection of E. uncinata Turcz. and E. oleosa F. Muell., and designated the fragment of E. oleosa as 'the true type' (now to be regarded as the Lectotype), stating that it was collected from the Murray Mallee.

= E. turbinata Behr et F. Muell. ex Miq., Ned. Kruidk. Arch. 4: 137 (1856).

Type: South Australia: Salts's Creek [sic], H. Behr (holo MEL; iso K). Cited as 'In sylva Pine-forest trans flumen Salts-creek, fl. aestate (Dr. Behr).' E. turbinata was included

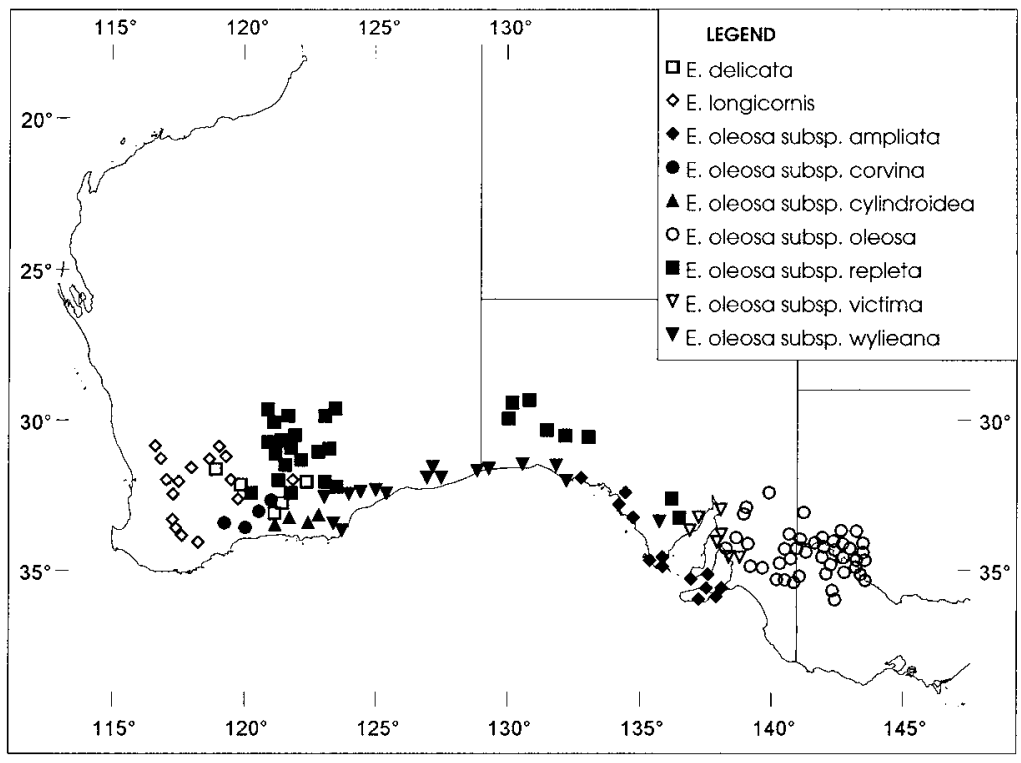

Fig. 2. Distribution of E. delicata, E. longicornis, E. oleosa subsp. oleosa, subsp. repleta, subsp. wylieana, subsp. corvina, subsp. cylindroidea, subsp. victima and subsp. ampliata. 
in E. oleosa by Bentham (1867), although material of E. dumosa and E. socialis was also included in the Behr specimens examined by Mueller and Miquel.

[E. laurifolia Behr ex Maiden, Crit. Revis. Eucalyptus 2: 167 (1912), in syn., nom. nud.]

[E. socialis F. Muell. ex Miq. var. laurifolia F. Muell. ex Maiden, Crit. Revis. Eucalyptus 2: 167 (1912), in syn., nom nud.]

Mallee or small tree to $10 \mathrm{~m}$ tall. Bark persistent on lower trunk, finely fibrous-flaky, grey; smooth, white and grey-white above. Adult leaves disjunct, lanceolate to broad-lanceolate, acute or acuminate, highly glossy, $5.0-9.0 \mathrm{~cm}$ long, $0.9-2.0 \mathrm{~cm}$ wide; petioles terete or slightly flattened, $0.9-2.0 \mathrm{~cm}$ long; lateral veins at c. $45^{\circ}$ to midrib, regular, moderately spaced; secondary reticulum open; intramarginal vein distinct, $0.5-1.5 \mathrm{~mm}$ from margin. Umbellasters axillary, 7-flowered; peduncles terete, 4-15 $\mathrm{mm}$ long; pedicels terete,1-5 mm long. Mature buds ovoid or elongate-ovoid to cylindrical, 5-11 mm long, 3-6 mm diam.; calyptra hemispherical to conical or oblong, acute, obtuse or rounded, smooth or finely verrucose, 1-2 times longer than hypanthium, narrower to slightly wider than hypanthium. Stamens all fertile; filaments variably flexed in bud, with outer filaments erect and inner filaments regularly inflexed; anthers subglobular, \pm basifixed, versatile; connective gland large; cells divergent, dehiscing by short slits. Fruits ovoid to globular, apically constricted, 3-5-locular, 4-8 mm long, 4-8 mm diam.; calyptra scar \pm raised, c. $0.5 \mathrm{~mm}$ wide; stemonophore sharply depressed, less than $0.5 \mathrm{~mm}$ wide; disc slightly to strongly depressed, 1-1.5 mm wide; valves deeply enclosed basally, acuminate tips vertically exserted, remnants of persistent style forming tips of valves. Seeds semiglossy, dark greybrown, rounded, finely and shallowly reticulate, 1-2 $\mathrm{mm}$ long; hilum ventral; chaff similar, smaller glossy pale brown.

Distinguished within the series by the following: Mallee or sometimes tree. Bark persistent on lower trunk. Juvenile leaves linear, sessile, spirally arranged, crowded ('ericoid'). Oil glands in leaves small to medium, sparse to moderately dense. Peduncles and pedicels short to moderately long. Calyptra acute or rounded, 1-2.5 times longer than hypanthium, usually not smoothly and regularly tapered.

E. oleosa is an extremely widespread and variable species, ranging from western New South Wales west to the Goldfields region of Western Australia (Fig. 2), and occurring on a range of substrates. Considerable morphological variation is evident across this range, both on a local, environmentally correlated scale, and regionally with a broader basis. Regional variants show a clear geographic replacement pattern, and are here recognised as subspecies (Table 2).

\section{A. Eucalyptus oleosa subsp. oleosa}

Oil glands crowded. Peduncles medium to long, slender (5-11 mm). Pedicels medium to long, slender (1-3 mm). Buds medium, ovoid (6-8 mm long, 4-5 mm diam.). Calyptra distinctly narrower than hypanthium at junction, oblong, rounded. Fruits small to medium, ovoid to globular (5-7 mm long, 5-7 mm diam.) (Fig. 3).

Locally abundant in mallee communities on red sandy soils, from Terowie and Yunta to the 'Murray Mallee' communities in South Australia, extending into the mallee communities of Victoria, and the more south-westerly mallee communities of New South Wales, northeast to near Hatfield (Fig. 2).

Hybrids are known with E. socialis.

Conservation status: not considered to be at risk. 

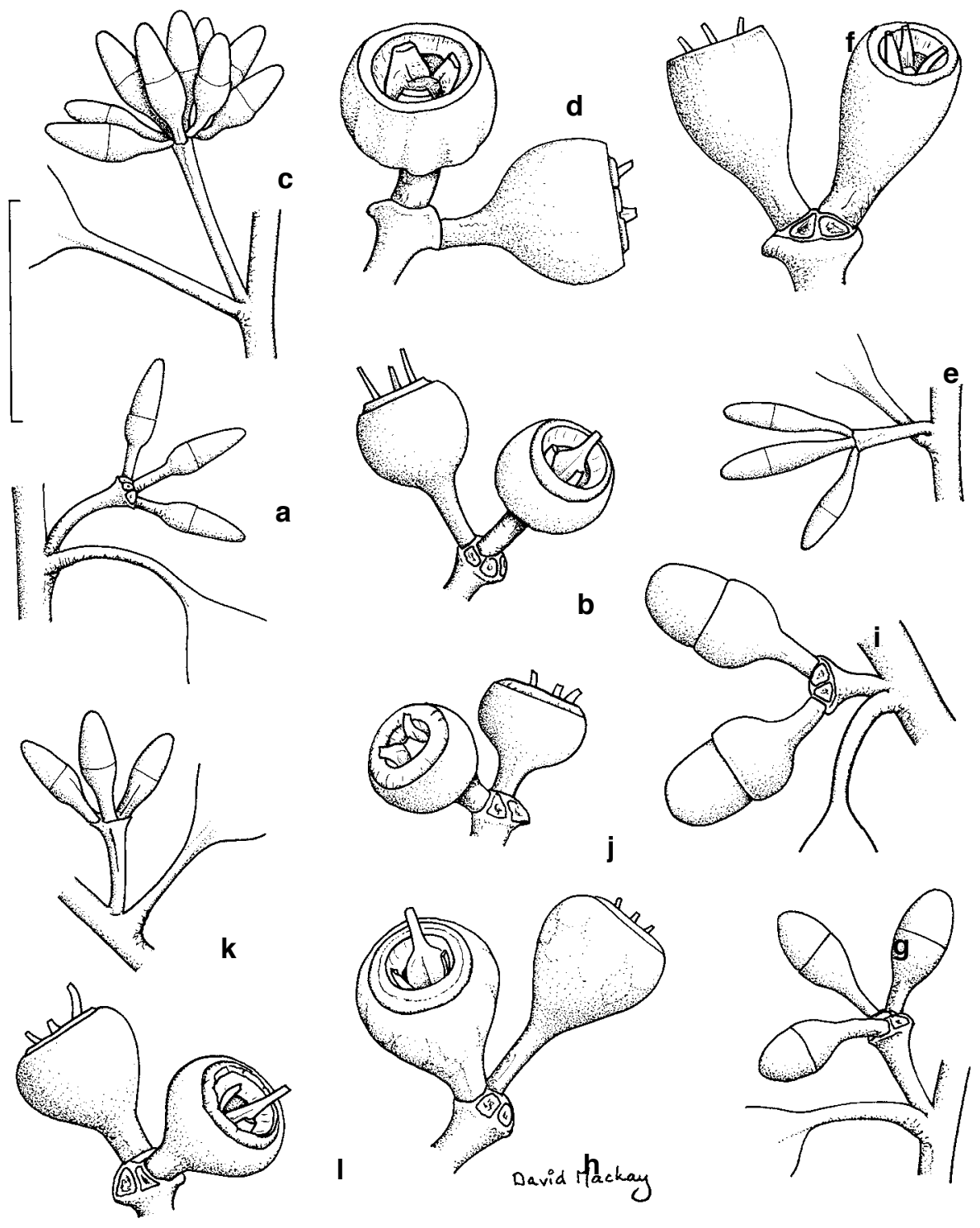

Fig. 3. E. oleosa. Subsp. oleosa. a, buds. b, fruits (from Wilson 3271). Subsp. ampliata. c, buds. d, fruits (from Hill 157). Subsp. cylindroidea. e, buds. f, fruits (from Brooker 8673). Subsp. repleta. g, buds. h, fruits (from Brooker 5602). Subsp. victima. i, buds. j, fruits (from Copley 1841). Subsp. wylieana. k, buds. 1, fruits (from Hill 163). Scale bar: buds $=2 \mathrm{~cm}$; fruits $=1 \mathrm{~cm}$. 
Table 2. The subspecies of $E$. oleosa.

All measurements in $\mathrm{mm} ; \mathrm{I} \times \mathrm{w}=$ length $\times$ width.

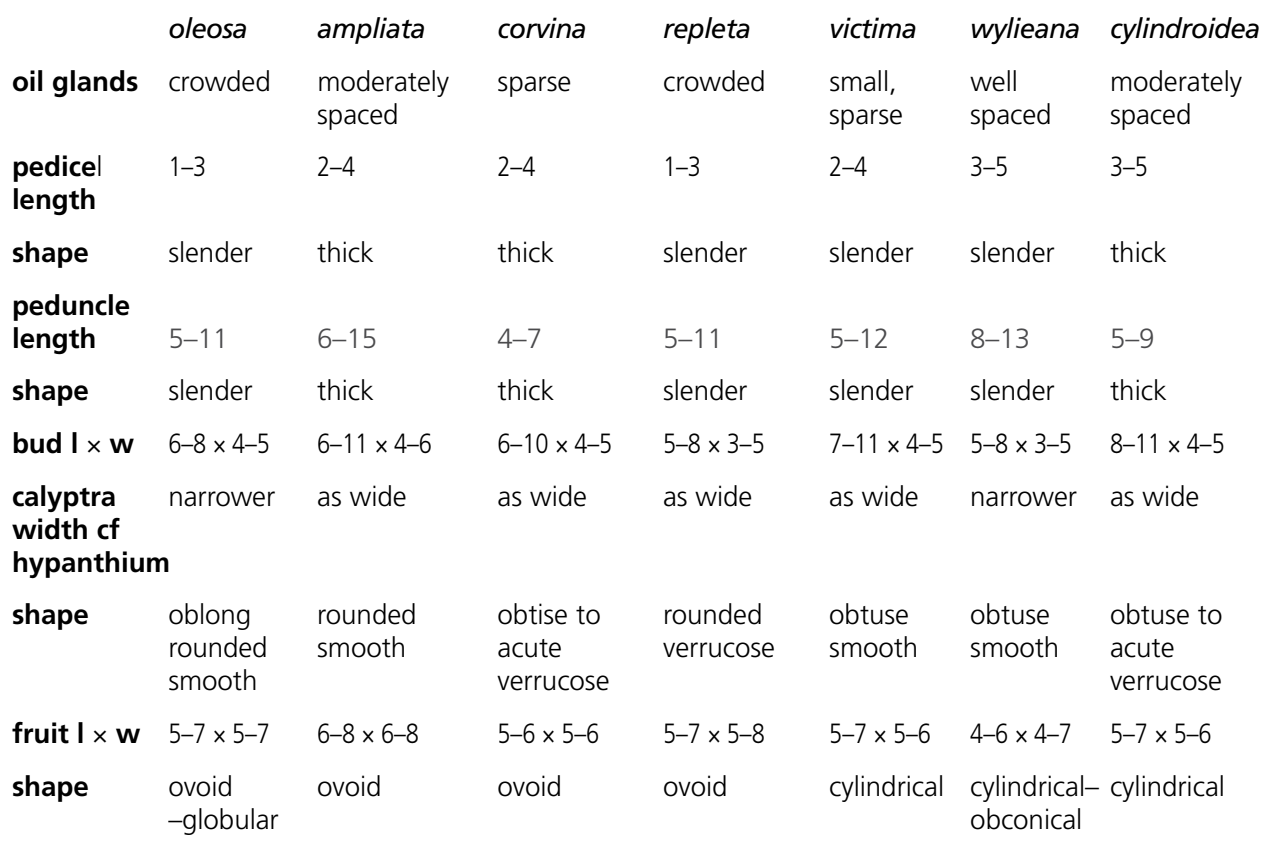

\section{Key to Subspecies}

1 Calyptra narrower than hypanthium at join, rounded

2 Pedicels short (1-3 mm)

3A. subsp. oleosa

2* Pedicels long (3-5 mm )

3E. subsp. victima

1 Calyptra not narrower than hypanthium at join, rounded or pointed

3 Calyptra smooth

4 Leaves broad, buds large $(6-11 \times 4-6 \mathrm{~m})$; fruits $6-8 \times 6-8 \mathrm{~mm}$

3F. subsp. ampliata

$4^{*}$ Leaves narrow, buds slender $(5-8 \times 3-5 \mathrm{~m})$; fruits $4-6 \times 4-7 \mathrm{~mm}$

3G. subsp. wylieana

3* Calyptra minutely verrucose rounded

5 Pedicels and peduncles slender, buds short $(5-8 \times 3-5 \mathrm{~mm})$, calyptra short,

3B. subsp. repleta pointed

$5^{*}$ Pedicels and peduncles thick, buds long $(6-11 \times 4-5 \mathrm{~mm})$, calyptra long,

6 Pedicels short (2-4 mm), peduncles short (4-7 mm), fruits ovoid

3D. subsp. corvina

6 Pedicels long (3-5 mm), peduncles long (5-9 mm), fruits cylindrica

3C. subsp. cylindroidea 
Selected specimens (from 109 examined): New South Wales: South Far Western Plains: c. $1.5 \mathrm{~km}$ by road SW of turnoff to Renmark on road to Broken Hill, Barker 4192, 9 Sep 1980 (AD, NSW); 2 miles [3.2 km] W of Balranald, Brooker Bal 10, 24 Aug 1964 (GAUBA, NSW); $6.7 \mathrm{~km} \mathrm{~S}$ of Tara Downs mailbox on Darling R Anabranch Mail Rd, Brooker 10312, 10 Oct 1989 (CANB, AD, MEL, NSW); 9 miles [14.4 km] from Mildura on Euston Road, Burbidge 6645, 24 July 1960 (CANB, NSW); Balranald, Constable NSW 15714, 10 Oct 1947 (NSW); 53 km west of Robinvale on Sturt Highway, Fox 7905091, 28 May 1979 (NSW); $3 \mathrm{~km}$ N on Ana Branch Hall road, $16 \mathrm{~km} \mathrm{~W}$ of Wentworth, Fox 7910090,9 Oct 1979 (NSW); 38 km from Lethero turnoff on Pooncarie to Mungo road, Fox 8105320, 28 May 1981 (NSW); on Nulla Road $4.5 \mathrm{~km}$ from junction of Renmark Road, c. $25 \mathrm{~km}$ NW of Wentworth, Fox 8304055 \& Fallding, 28 Apr 1983 (NSW); ca. 25 miles [40 km] WNW of Euston, Johnson NSW344542 (NSW); c. 24 miles [38.4 km] NE of Wentworth, Johnson NSW344549, 26 May 1969 (NSW); abt 12 M [19.2 km] E of Wampo towards Boree Plains (between Turlee and Hatfield), Johnson \& Constable, 19 Mar 1959 (NSW); 2 miles [3.2 km] west of Balranald, Moore 3716, 4 July 1966 (CANB, NSW); Bidura, about 40 miles [64 km] North of Balranald, Moore 6119, 14 Oct 1971 (CANB, NSW); near Tapalin Mail-run turn off on Sturt Hwy, about $30 \mathrm{~km}$ east of Euston, Noble 1038, 1039, 5 May 1977 (NSW); 10 km along Arumpo Road from Sturt Highway, about 40 km west of Balranald, Noble 1043, 5 May 1977 (NSW); Mindook Station, Euston, Noble \& Bawden, Aug 1979 (NSW); The Peppers, abt $15 \mathrm{ml}$ [24 km] north of Penarie (Homebush) 7629 site 10, Semple s.n, 27 Apr 1982 (NSW); 3 km W of Balranald on Sturt Highway, Turner 93 \& Vos, 13 Sep 1977 (CANB, AD, MEL, NSW, PERTH); $11 \mathrm{~km}$ SW of Bellnar HS [Homestead] on Arumpo to Buronga road, Wilson 3271, 4 Dec 1980 (NSW); 16 km W of Balranald on Euston road, Wilson 3286, 4 Dec 1980 (NSW). South Western Plains: 2 miles [3.2 km] NW of Koraleigh, 40 miles [64 km] S of Balranald, Johnson NSW344422, 28 May 1969 (NSW).

South Australia: Near entrance to Horrocks Pass, Brooker H 1, 17 Nov 1963 (GAUBA, NSW); Dublin, Brooker D 9, 20 Nov 1963 (GAUBA, NSW); Wanbi, Brooker Wan 5, Jan 1964 (GAUBA, NSW); N of Pinnaroo, Brooker Pin 3, Jan 1964 (GAUBA, NSW); Between Truro and Blanchetown, Brooker Bl 4, 22 Nov 1964 (GAUBA, NSW); Spring Dam, via Yunta, Brooker 2814, 4 Sep 1970 (CANB, NSW); $1 \mathrm{~km} \mathrm{~W}$ of Oodla Wirra, Brooker 7429, 23 Apr 1982 (CANB, NSW); 10 miles [16 km] W of Mannum, Cleland, 26 Nov 1913 (NSW); Alawoona, Cleland 21, 8 Dec 1913 (NSW); Berri, Cleland 24, Jan 1921 (NSW); Murray Basin district; Morgan to Eudunda road, $2.8 \mathrm{~km}$ WSW of Sutherlands, NW side of road, Davies 1387 \& Hadlow, 22 Nov 1989 (CANB, AD, MEL, NSW); Parilla [Forest Reserve], Gill, 17 Sep 1919 (NSW); Dilkera near Mt Mary, Ising 1937, 5 Oct 1922 (NSW); Renmark to Berri, Johnson, 18 Aug 1958 (NSW); c. 36 direct NNW of Renmark, Calperum property, Amalia Dam, Lyne 1719 \& Hallett, 22 Nov 1995 (CANB, AD, NSW); Murray Desert, Mueller, 1847 (MEL, NSW); 5 km NE of Terowie, Noble 16 \& Bawden, Feb 1981 (NSW); 16 km N Paruna to Loxton, Turner 101 \& Vos, 14 Sep 1977 (CANB, AD, MEL, NSW, PERTH).

Victoria: 24.4 miles [39 km] W of Mildura, Baker 170, 9 Apr 1971 (CANB, NSW); Murray Mallee: N of Meringur, Brooker Mer 2, Jan 1964 (GAUBA, NSW); between Ouyen and Piangil, Brooker 10178, 15 Mar 1989 (CANB, AD, MEL, NSW, PERTH); 9.4 km E of Walpeup towards Galah, Brooker 10266, 5 Sep 1989 (CANB, AD, MEL, NSW); ca 25 km WNW of Nowingi (N of Raak Plain), Brooker 10323, 11 Oct 1989 (CANB, AD, MEL, NSW); Nyaah, Narrung, Euston, Mildura, Brownscombe 15 A, Aug 1907 (NSW); 13.2 km W Murrayville towards Pinnaroo, Chippendale 1384 \& Brennan, 23 July 1975 (CANB, NSW); near Beulah, Connor, 18 June 1962 (BRI, NSW); Sturt Hwy, between Renmark (SA) and Mildura, $1 \mathrm{~km}$ E of state border, Mallee district, Crisp 8136, 4 Jan 1988 (CANB, NSW, PERTH); Swan Hill, Griffiths, 1888 (MEL, NSW); c. 5 km W of Hopetoun on Albacutya road, Johnson 7963 \& Wilson, 20 Feb 1975 (NSW); 4 miles [6.4 km] west of Swan Hill, Moore 3606, 16 Feb 1966 (CANB, NSW); on western edge of Raak Plain, Grid A 33, Short 1236, 27 Sep 1981 (MEL, NSW); $41 \mathrm{~km} \mathrm{~W}$ of Mildura, Sturt Highway, Turner 96 \& Vos, 14 Sep 1977 (CANB, AD, MEL, NSW, PERTH); 43 km E Ouyen to Manangatang, Turner 127 \& Vos, 19 Sep 1977 (CANB, AD, MEL, NSW, PERTH).

\section{B. Eucalyptus oleosa subsp. repleta L.A.S. Johnson E K.D. Hill, subsp. nov.}

Glandulae oleiferae numerosae densaeque; calyptra basi quam hypanthio non angustior, brevis, rotundata, minute verrucosa; pedicelli pedunculique graciles; alabastra brevia (5-8 × 3-5 mm).

Type: South Australia: $7 \mathrm{~km}$ E of Immarna along transcontinental railway line (30 $31^{\circ} \mathrm{S}$ $132^{\circ} 12^{\prime} \mathrm{E}$ ), J.Z. Weber 6619, 1 Sep 1980 (holo NSW; iso AD). 
= Eucalyptus oleosa var. obtusa C. Gardner, J. \& Proc. Roy. Soc. Western Australia. 34: 77 (1950).

Type: Western Australia: Montana Hill, Coolgardie, C.A. Gardner 1839 (holo PERTH).

[Eucalyptus sp. N, Brooker \& Kleinig (1990)]

Oil glands crowded. Peduncles medium to long, slender (5-11 mm). Pedicels medium to long, slender (1-3 mm). Buds short, broad (5-8 mm long, 3-5 mm diam.). Calyptra as wide as hypanthium, hemispherical to conical, rounded to obtuse, finely verrucose. Fruits small to medium, ovoid (5-7 mm long, 5-8 mm diam.) (Fig. 3).

Long-budded forms of this have been taken for E. longicornis, which differs in having a more acute and smooth calyptra with a lower hypanthium to calyptra ratio.

Widespread and abundant on sandy soils or desert sandhills, both cases usually somewhat calcareous. From Norseman to Balladonia, north to Goongarrie in Western Australia, and east through the sandhill country to the north of the Nullarbor Plain, extending to the northern Eyre Peninsula in South Australia (Fig. 2). This taxon is usually a mallee over most of its range, but includes both mallees and morrell-like trees in the goldfields region of Western Australia, and a full range of intermediate forms.

Subspecies repleta, wylieana and cylindroidea come together in the Norseman-BalladoniaSalmon Gums area, and a range of intermediates occurs. Subsp. repleta occurs on sandy sites, with subsp. wylieana on highly calcareous limestone soils and subsp. cylindroidea on clay-loam although still calcareous soils in higher rainfall areas.

The epithet is from the Latin, repleta, full, referring to the turgid buds which lack any median constriction.

Conservation status: not considered to be at risk.

Selected specimens (from 79 examined): South Australia: c. $3 \mathrm{~km}$ NE of the Kallimba entrance on the Darke Peak to Curtinye road, c. 16 km SSE of Kimba, Eyre Peninsula district, J. Briggs 1096, 29 Aug 1983 (CANB, MEL, NSW); 27 km N of Watson towards Maralinga, Brooker 5602, 1 Apr 1977 (CANB, AD, MEL, NSW, PERTH); 19.4 km E of Ooldea, Brooker 9286, 21 May 1986 (CANB, NSW); between Ooldea and Immarna [19.4 km E of Ooldea], Brooker 9287, 21 May 1986 (CANB, NSW); $147 \mathrm{~km} \mathrm{~N}$ of Cook towards Vokes Junction, Brooker 9419, 28 Aug 1986 (CANB, NSW); Ooldea, Cleland 65, 70, Aug 1922 (NSW); Maralinga Sand Plain to Lake Dey Dey, Dennis 305 b, 21 Feb 1982 (AD, NSW); Barton, Ising, 19 Sep 1920 (NSW); ca. 1 km south of Maralinga check point, Lothian 4011, 2 June 1967 (AD, NSW).

Western Australia: 0.6 miles [1 km] W of Eyre Highway, 9.5 miles [14.4 km] S of Norseman, Baker 52, 12 Nov 1970 (CANB, NSW); Comet Hill, Brooker 6462, 23 Aug 1979 (CANB, NSW); 13.6 km from highway at Coolgardie on Gnarlbine Rock road, Brooker 9065, 11 Nov 1985 (CANB, NSW); 5 $\mathrm{km}$ S of Coolgardie on Burra Rock road, Brooker 9071 \& 9072, 12 Nov 1985 (CANB, NSW); between Broad Arrow and Kalgoorlie, Brooker 9082, 9083, 9084, 9085, 13 Nov 1985 (CANB, NSW); 46 km E of Karonie, Brooker 9098, 14 Nov 1985 (CANB, NSW); $56.6 \mathrm{~km} \mathrm{~N}$ of Coolgardie, Brooker 9590, 5 May 1987 (CANB, NSW); $35.2 \mathrm{~km}$ E of 3rd grid on Tonkin highway, Brooker 9613, 6 May 1987 (CANB, NSW); Lake Minigwal, east end, $16.8 \mathrm{~km}$ E from main fork, Brooker 9670, 25 June 1987 (CANB, NSW); 8.4 km SE of Lake Minigwal on Officer Basin track, Brooker 9677, 25 June 1987 (CANB, NSW); 8.4 km NW of Menzies on Sandstone road, Brooker 9663, 23 June 1987 (CANB, NSW); 9.6 miles [15.4 km] SE of Coolgardie, Chippendale 373, 23 Mar 1968 (CANB, NSW); Widgiemooltha, Gardner 1754, 27 Sep 1922 (PERTH, AD, CANB, MEL, NSW); 70 miles [112 km] NW from Fraser Range, Helms, 8 Nov 1891 (NSW); 14 km E of Balladonia roadhouse on Hwy 1, Hill 206 \& Johnson, 19 Oct 1983 (NSW, CANB, PERTH); $5 \mathrm{~km} \mathrm{~S} \mathrm{of} \mathrm{Goongarrie} \mathrm{rly} \mathrm{[railway]} \mathrm{station}$ on hwy, Hill 545, Johnson, Blaxell \& Brooker, 4 Nov 1983 (NSW, CANB, PERTH); 38.4 km E of Karonie along railway, Hill 572, Johnson, Blaxell, Brooker \& Hopper, 5 Nov 1983 (NSW, CANB, PERTH); $61 \mathrm{~km} \mathrm{~W}$ of Balladonia roadhouse on hwy 1, Hill $703 \mathcal{E}$ Blaxell, 14 Nov 1983 (NSW, CANB, PERTH); $10.6 \mathrm{~km} \mathrm{~W}$ of Balladonia roadhouse on highway, Hill 2183 \& Johnson, 4 Nov 1986 (NSW, 
CANB, MEL, PERTH); $34.5 \mathrm{~km} \mathrm{~W}$ of Coolgardie to Norseman rd on Hyden track, Hill 2849, 25 Aug 1988 (NSW, CANB, PERTH); $98.5 \mathrm{~km}$ E of Hyden on Hyden to Norseman rd (ie $11.7 \mathrm{~km}$ E of Crossroads), Johnson 9102 \& Johnson, 17 May 1988 (NSW, PERTH).

3C. Eucalyptus oleosa subsp. cylindroidea L.A.S. Johnson E K.D. Hill, subsp. nov.

Folia plerumque rigidiuscula erectaque; glandulae oleiferae moderate numerosae densaeque; calyptra basi diametro hypanthium aequans, convexoconica, rotundata ad acuta, minute verrucosa; fructus parvi ad mediocres, cylindrici (5-7 ×5-6 mm).

Type: Western Australia: $14.5 \mathrm{~km} \mathrm{~N}$ of Rollonds rd on Fields rd (33 $\left.03^{\prime} \mathrm{S} 121^{\circ} 11^{\prime} \mathrm{E}\right)$, M.I.H. Brooker 8673, 7 Sep 1984 (holo NSW; iso AD, CANB, MEL, PERTH).

Oil glands medium density. Peduncles medium to long, thick (5-9 mm). Pedicels long, thick (3-5 mm). Buds medium to long, cylindrical (8-11 mm long, 4-5 mm diam.). Calyptra as wide as hypanthium, convex-conical, rounded to acute. Fruits small to medium, cylindrical (5-7 mm long, 5-6 mm diam.). (Fig. 3).

Foliage is usually stiff and erect in this taxon, and the calyptra usually finely verrucose.

Locally abundant as a tree or mallee on heavier, clayier and more calcareous soils in subcoastal country northwest to northeast of Esperance (Fig. 2).

The epithet is from the Latin cylindrus, a cylinder, with the termination -oides, resembling, from the more or less cylindrical fruits.

Conservation status: not considered to be at risk.

Selected specimens (from 8 examined): Western Australia: 30 miles [48 km] NE of Mt Ney coastalA, Beard 6376, 17 Sep 1970 (KPBG, NSW); c. 5 km N of Salmon Gums, Brooker 8906 a, 7 Apr 1985 (CANB, NSW); 3.6 miles [5.8 km] SSE of Salmon Gums, Chippendale 393, 24 Mar 1968 (CANB, NSW); $19 \mathrm{~km}$ south of Salmon Gums on Norseman to Esperance highway, Hill 2245, Johnson, Brooker, \& Blaxell, 5 Nov 1986 (NSW, CANB, MEL, PERTH); $1.5 \mathrm{~km}$ SE of Mt Ney road on Howick road, Hill 2280 \& Johnson, 6 Nov 1986 (NSW, CANB, MEL, PERTH).

3D. Eucalyptus oleosa subsp. corvina L.A.S. Johnson E K.D. Hill, subsp. nov.

Subspeciei wylianae affinis sed differt calyptra acutiore inflatioreque et pedicellis delicatioris. Ut in subspeciei wyliana glandulae oleiferae relative sparsae et calyptra minute verrucosa.

Type: Western Australia: $9 \mathrm{~km} \mathrm{~W}$ of Ravensthorpe to Hopetoun road on road 11, a mining access track ( $\left.33^{\circ} 41^{\prime} \mathrm{S} 120^{\circ} 05^{\prime} \mathrm{E}\right)$, K. Hill 2374, L.A.S. Johnson, D.F. Blaxell \& M.I.H. Brooker, 9 Oct 1986 (holo NSW; iso PERTH).

Oil glands relatively sparse. Peduncles short, thick (4-7 mm). Pedicels medium to long, thick (2-4 mm). Buds medium, ovoid (6-10 mm long, 4-5 mm diam.). Calyptra as wide as hypanthium, convex-conical, obtuse to acute. Fruits medium, ovoid (5-6 mm long, 5-6 mm diam.). (Fig. 3).

This taxon is close to subsp. wylieana, from which it differs in the more acute and more inflated calyptra, and the more delicate pedicels. It occurs on similarly calcareous sites.

Locally frequent on shallow, somewhat calcareous soils in the Ravensthorpe region (Fig. 2).

The epithet is from the Latin corvus, a crow or raven, an allusion to the occurrence around Ravensthorpe.

Conservation status: not considered to be at risk. 
Selected specimens (from 11 examined): Western Australia: c. $0.3 \mathrm{~km}$ E of Lake King t/o [turnoff] on Ravensthorpe to Albany road, Brooker 9642 a, 19 May 1987 (CANB, NSW); 1 km W along Aerodrome Road from Lake King to Ravensthorpe road, Brooker 9644, 19 May 1987 (CANB, NSW); $16 \mathrm{~km} \mathrm{~S}$ of Ravensthorpe along road to Hamersley River estuary, Eyre district, Crisp 5003, 10 Jan 1979 (CANB, NSW, PERTH); 42.5 km from Highway on Peak Charles road, Hill 2328 Johnson \& Blaxell, 8 Nov 1986 (NSW, CANB, MEL, PERTH); $26.7 \mathrm{~km}$ past Fields road (5 ways) on Ravensthorpe track, Hill 2338 Johnson \& Blaxell, 8 Nov 1986 (NSW, PERTH); $5.2 \mathrm{~km} \mathrm{~W}$ of Giles road (Findley road), on Magenta road, Hill 2398, Johnson, Blaxell \& Brooker, 10 Nov 1986 (NSW, PERTH); $13.5 \mathrm{~km} \mathrm{~W}$ of Ravensthorpe on Hwy 1 (E of Phillips R), Johnson 9063 \& Johnson, 13 May 1988 (NSW, PERTH); Ravensthorpe, Maiden, Nov 1909 (NSW).

3E. Eucalyptus oleosa subsp. victima L.A.S. Johnson E K.D. Hill, subsp. nov.

Glandulae oleiferae parvae, sparsiusculae; calyptra basi diametro hypanthio angustior, rotundata; pedicelli longiusculi $(3-5 \mathrm{~mm}$ ) or 2-4 $\mathrm{mm}$ (check), fructus parvi ad mediocres, cylindrici $(5-7 \times 5-6 \mathrm{~mm})$.

Type: South Australia: c. 4 km from Bute on Wokurna rd (c. $130 \mathrm{~km}$ NNW of Adelaide), B. Copley 1650, 5 July 1967 (holo NSW; iso AD).

Oil glands small, relatively sparse. Peduncles medium to long, slender (5-12 mm). Pedicels medium to long, slender $(2-4 \mathrm{~mm})$. Buds medium, ovoid (7-11 mm long, 4-5 mm diam.). Calyptra narrower than hypanthium, with a distinct constriction where the two join, convex-conical, obtuse. Fruits small to medium, \pm cylindrical (5-7 mm long, 5-6 mm diam.). (Fig. 3).

A rare taxon in mallee communities on loamy soils in northern Yorke Peninsula and central-eastern Eyre Peninsula (Fig. 2). Much of this country has been cleared for farming.

The epithet is from the Latin victima, a beast for sacrifice, i.e. a victim, in allusion to the great reduction in the populations by clearing for pastoral and agricultural usage.

Conservation status: severely reduced in extent, and under significant threat. A code of $3 \mathrm{~V}$ is appropriate.

Selected specimens (from 12 examined): South Australia: Dublin Scrub [ca $48 \mathrm{~km} \mathrm{NNW}$ of Adelaide, Black 10, 25 Dec 1907 (NSW); $3 \mathrm{~km} \mathrm{~S}$ of Gawler to Balaklava road on road to Mallala, Brooker 6935, 11 May 1980 (CANB, AD, NSW); ca. 5 km north of Bute on Wolurna Road (Bute is ca. 130 km north-north-west of Adelaide), Copley 514, 23 Aug 1966 (AD, NSW); Hundred of Ninnes, Section 9, in farmyard (Ninnes is about $32 \mathrm{~km} \mathrm{NW}$ of Port Wakefield), Copley 1234, $26 \mathrm{Mar}$ 1967 (AD, NSW); Northern Yorke Peninsula, Hundred of Wiltunga, south-west corner of section 156 (Hundred of Wiltunga is ca. 140 km north-north-west of Adelaide), Copley 1841, 9 Feb 1968 (AD, NSW); $44 \mathrm{~km}$ from Whyalla on Cowell road, Hill 2142 \& Johnson, 1 Nov 1986 (NSW, AD, CANB, MEL, PERTH); Port Germein to Wirrabarra rd, above picnic area near eastern t/o to Telowie Gorge, Hill 2801, 22 Aug 1988 (NSW, AD, CANB); roadside near Cowell, Noble 14 \& Bawden, Feb 1981 (NSW).

\section{F. Eucalyptus oleosa subsp. ampliata L.A.S. Johnson $\mathcal{E}$ K.D. Hill, subsp. nov.}

Glandulae oleiferae moderate dispersae; calyptra basi diametro hypanthium aequans; convexoconica et rotundata, laevis; fructus relative magni, ovoidei; ramuli foliaque grossiuscula, fructus majusculi, ovoidei $(6-8 \times 6-8 \mathrm{~mm})$.

Type: South Australia: $11.6 \mathrm{~km} \mathrm{~W}$ of Wirrula on Eyre Highway (32 $\left.25^{\prime} \mathrm{S} 134^{\circ} 24^{\prime} \mathrm{E}\right)$, K. Hill 157 E L.A.S. Johnson, 16 Oct 1983 (holo NSW).

Oil glands moderately spaced. Peduncles medium to long, thick (6-15 mm). Pedicels medium to long, thick (2-4 mm). Buds long, ovoid (6-11 mm long, 4-6 mm diam.). Calyptra as wide as hypanthium, convex-conical, rounded. Fruits large, ovoid (6-8 mm long, 6-8 mm diam.) (Fig. 3). 
Leaves are relatively coarse and broad with prominent lateral veins and twigs are angular in this taxon.

Locally frequent in coastal and subcoastal mallee communities in calcareous sand, northwestern to southern Eyre Peninsula, southern Yorke Peninsula, Cape Jervis and Kangaroo Island (Fig. 2).

The epithet is from the Latin ampliatus, increased, from the larger leaves buds and fruits in comparison to the other subspecies.

Conservation status: not considered to be at risk.

Selected specimens (from 26 examined): South Australia: Little Sahara on south coastal highway, Kangaroo Island, Blaxell 2038 \& Johnson, 11 June 1983 (NSW, AD, CANB, MEL, PERTH); 26.7 km on road to Penneshaw from turnoff on Playford Hwy, Kangaroo Island, Blaxell 2039 E Johnson, 12 June 1983 (NSW, AD, CANB); 2 km S of Cape Donington, near Port Lincoln, Brooker 7440, 24 Apr 1982 (CANB, NSW); 18 km N of Streaky Bay on Highway 1, Brooker 7452, 25 Apr 1982 (CANB, NSW); c. $1.5 \mathrm{~km}$ SE of Sapphiretown, Brooker 8278, 19 Aug 1983 (CANB, NSW); Stenhouse Bay, Yorke Peninsula, Brooker 8455, 5 Mar 1984 (CANB, NSW); Kangaroo Is., 3 km S of Bay of Shoals turn-off on N Coast rd, Brooker 10235, 11 July 1989 (NSW); Bay iii [Fowlers Bay], Brown B, 1802-1805 (BM, NSW); Lake Wangary, 30 miles [48 km] W of Port Lincoln, Cleland 120, May 1923 (NSW); near Bay of Shoals, Crocker, Nov 1940 (NSW); Pelican Lagoon Peninsula, Kangaroo Island, Dennis 315, 2 Dec 1983 (AD, NSW); Track going from main road to Taylors Landing from Pillie Lake c. $3 \mathrm{~km}$ from the gate, Donner 11102, 4 Nov 1985 (AD, NSW); Waterloo Bay, Yorke Peninsula, Heyligers 80120, 8 Oct 1980 (CANB, AD, CANB, NSW); $7 \mathrm{~km} \mathrm{~W}$ of Wirrulla on Hwy 1, Hill 155, 156 \& Johnson, 16 Oct 1983 (NSW); 13.1 km SE of Port Kenney on coastal hwy Hill, 2807, 22 Aug 1988 (NSW, CANB, PERTH); Cape Jervis, Maiden, Jan 1907 (NSW); between Streaky Bay and Ceduna, Noble 25 \& Bawden, Feb 1981 (NSW); 34 miles [54.5 km] from Yorketown, Yorke Peninsula, towards Stenhouse Bay, Phillips, 18 Oct 1966 (CANB, NSW); Fowlers Bay, Rogers, Sep 1907 (NSW); $10 \mathrm{ml}$ [16 km] from Port Lincoln, along Memory Cove road, Wrigley WA/68-7630, 20 Nov 1968 (CANB, NSW).

\section{G. Eucalyptus oleosa subsp. wylieana L.A.S. Johnson \& K.D. Hill, subsp. nov.}

Glandulae oleiferae relative sparsae; calyptra quam hypanthium angustior, basi ad hypanthium expansa, apice rotundata vel conica, obtusa; fructus parvi, plus minusve cylindrici vel obconici (4-7 mm diam). Alabastra saepe costata et nitida; discus plus evidens quam plerumque intra E. oleosam.

Type: Western Australia: bottom of Madura Pass (31 53'S $\left.127^{\circ} 03.5^{\prime} \mathrm{E}\right)$, L.D. Pryor $\mathcal{E}$ J.D. Briggs 199, 27 Oct 1978 (holo NSW; iso CANB, PERTH).

Oil glands well-spaced. Peduncles medium to long, slender (8-13 mm). Pedicels long, slender (3-5 mm). Buds short, broad (5-8 mm long, 3-5 mm diam.). Calyptra narrower than hypanthium, flared at base to meet hypanthium, rounded or conical, obtuse. Fruits small, \pm cylindrical or obconical (4-6 mm long, 4-7 mm diam.). (Fig. 3).

Buds are often ridged and glossy, and the disc is more exposed in this taxon.

A frequent tree or mallee in strongly calcareous sand or loam on limestone, from Balladonia in Western Australia to west of Eyre Peninsula in South Australia (Fig. 2).

The epithet is from Wylie, Aboriginal companion and guide to Edward John Eyre in his journey around the Great Australian Bight, the region in which this subspecies occurs.

Conservation status: not considered to be at risk.

Selected specimens (from 33 examined): South Australia: Highway 1 at turnoff to Cook, Brooker 5610, 2 Apr 1977 (CANB, AD, MEL, NSW, PERTH); $30.4 \mathrm{~km} \mathrm{~W}$ of Nullarbor, Brooker 9412, 27 Aug 1986 (CANB, NSW); $4.5 \mathrm{~km}$ E of Yalata roadhouse on Hwy 1, Hill 163 \& Johnson, 16 Oct 1983 (NSW); $3.4 \mathrm{~km} \mathrm{~N}$ of Hwy 1 on track turning off $152.5 \mathrm{~km} \mathrm{~W}$ of Nullarbor roadhouse, Hill 183 
$\mathcal{E}$ Johnson, 18 Oct 1983 (NSW, AD, CANB, PERTH); $31.2 \mathrm{~km}$ E of SA-WA border on Old highway, Hill $188 \mathcal{E}$ Johnson, 18 Oct 1983 (NSW); $3.1 \mathrm{~km}$ E of SA-WA border on old highway, Hill $190 \mathcal{E}$ Johnson, 18 Oct 1983 (NSW); 3 km from Fowlers Bay settlement on coast road to Penong (Penong, $40 \mathrm{~km}$ W of Ceduna), Hill 2160 \& Johnson, 2 Nov 1986 (NSW, AD, CANB, MEL, PERTH); $51.5 \mathrm{~km}$ W of the Nundroo Motel on the Eyre Hwy (130.5 km W of Penong), Pryor 204 \& Briggs, 28 Oct 1978 (CANB, NSW).

Western Australia: $10 \mathrm{~m}$ [16 km] SW of Mt Ragged coastalA, Beard 6400, 18 Sep 1970 (KPBG, NSW); Eucla, back of Hotel, Brooker 7459, 26 Apr 1982 (CANB, NSW); $77.6 \mathrm{~km} \mathrm{~W}$ of Mundrabilla towards Madura, Brooker 8473, 11 Mar 1984 (CANB, NSW); 1.5 km from Israelite Bay track on Mt Ragged track, Brooker 8911, 8912, 8 Apr 1985 (CANB, NSW); Madura, Brooker 10171, 6 Mar 1989 (CANB, AD, MEL, NSW, PERTH); 5 km E of Eucla, Crisp 5654, 2 Feb 1979 (CANB, AD, NSW, PERTH); $44.9 \mathrm{~km} \mathrm{~W}$ of Caiguna on Hwy 1, Hill 202 \& Johnson, 19 Oct 1983 (NSW, CANB, PERTH); $18.8 \mathrm{~km}$ S of hwy on Balladonia to Mt Ragged track, Hill 3178, 9 Sep 1988 (NSW); Caiguna, Johnson 2139, 31 Aug 1967 (NSW).

\section{Intergrades between the subspecies}

E. oleosa subsp. ampliata $\leftrightarrow$ subsp. repleta

Selected specimens (from 5 examined): South Australia: ca $30 \mathrm{~km} \mathrm{WNW}$ of Ceduna, $1 \mathrm{~km} \mathrm{~N}$ of Koonibba Hill, Crisp 4749, 3 Jan 1979 (CANB, AD, NSW); 0.1 km W of Warramboo, Hill 2154, 2155 $\mathcal{E}$ Johnson, 2 Nov 1986 (NSW, CANB, MEL, PERTH); Murat and Denial Bays, Rogers, Sep 1907 (NSW); Petina, Eyre Peninsula, Spafford 2, Aug 1923 (NSW).

E. oleosa subsp. ampliata $\leftrightarrow$ subsp. victima

Specimens examined: South Australia: Spring Dam, via Yunta, Brooker 2810, 4 Sep 1970 (CANB, NSW).

E. oleosa subsp. ampliata $\leftrightarrow$ subsp. wylieana

Specimens examined: South Australia: $63 \mathrm{~km} \mathrm{~W}$ of Yalata on hwy 1, Hill 711 \& Blaxell, 15 Nov 1983 (NSW, AD, CANB, PERTH).

E. oleosa subspp. ampliata, wylieana, victima and repleta

A complex and variable population occurs in central-northern Eyre Peninsula. This population exhibits combinations of characters of several subspecies (subspp. ampliata, wylieana, victima and repleta), often different on adjacent trees, and the characters of all 4 subspecies appear to be present within the population. The integrity of the 4 contributing subspecies is maintained across their individual ranges, but a breakdown of this integrity appears to occur in this region where the 4 taxa adjoin. Although this constitutes quite a large area and a large population, there is no clear-cut morphological diagnosis, and the whole of this population must be regarded as an intergrade.

Selected specimens (from 12 examined): South Australia: Hambidge Conservation Park, $1 \mathrm{~km}$ SW of summit of Prominent Hill, Eyre Peninsula district, Briggs 1271, 29 Sep 1983 (CANB, AD, NSW); Kimba, on Eyre Hwy in Motel grounds, Blaxell 2053, 2054, 2054 A \& Johnson, 15 June 1983 (NSW); Mt Weedind [Wudinna Hill], a granite outcrop about 15 miles [24 km] south from the Gawler Ranges and 125 miles [200 km] a little west of north from Port Lincoln, Gill s.n., Dec 1912 (NSW); $43.6 \mathrm{~km}$ W of Kimba on highway, Hill 2152 \& Johnson, 2 Nov 1986 (NSW, AD, CANB, MEL, PERTH); near Pinkawillinie Conservation Park, west of Kimba; on unallotted crown land ca. 7 km north-east of Corrobinnie Hill, Jackson 4138, 5 Oct 1981 (AD, NSW); 27 miles [43.2 km] from Whyalla, towards Kimba, Phillips 142, 29 Aug 1968 (CANB, NSW); Minnipa on Eyres Peninsula, Spafford 12, June 1916 (NSW); Gawler Ranges, 6 km NW of Pine Lodge, SW Gawler Ranges, ca. 19 km WSW of Yardea, Symon 8188, 6 Oct 1972 (AD, NSW); ca. $10 \mathrm{~km} \mathrm{~N}$ of Koongawa, ca. $50 \mathrm{~km} \mathrm{~W}$ of Kimba, Region 7, Weber 6854, 4 Oct 1981 (AD, NSW); Mount Middleback, Cook Range, eastern side of Iron Duchess, Region 7, Whibley 7758, 22 Sep 1981 (AD, NSW).

E. oleosa subsp. cylindroidea $\leftrightarrow$ subsp. repleta 
Selected specimens (from 5 examined): Western Australia: 33.6 miles [ $53.8 \mathrm{~km}$ ] west of Balladonia towards Norseman, Brooker 2480, 14 Feb 1970 (PERTH, NSW); $41.5 \mathrm{~km} \mathrm{~S}$ of Norseman, Brooker 9503, 5 Nov 1986 (CANB, NSW); $25.1 \mathrm{~km}$ east of Norseman on highway 1, Hill 680 E Blaxell, 14 Nov 1983 (NSW, CANB, PERTH); $12.1 \mathrm{~km} \mathrm{~W}$ of Balladonia roadhouse on highway, Hill 2185 \& Johnson, 4 Nov 1986 (NSW, CANB, MEL, PERTH).

E. oleosa subsp. repleta $\leftrightarrow$ subsp. wylieana

Specimens examined: Western Australia: 15.9 miles [25.4 km] W of Curtin, Chippendale 135, 10 Mar 1967 (CANB, NSW); 16.7 km west of Balladonia roadhouse on Highway 1, Hill 209 \& Johnson, 19 Oct 1983 (NSW, CANB, PERTH); on the Balladonia track $40 \mathrm{~km}$ NE of its junction with the Fisheries Road and c. 9 km directly SW of Mt Ragged, McGillivray 3623 \& George, 1 July 1976 (NSW, K, PERTH).

\section{Eucalyptus delicata L.A.S. Johnson E K.D. Hill, sp. nov.}

$\mathrm{Ab}$ E. oleosa et E. longicorni distinguitur: folia parva angustaque et alabastra fructusque parvi.

Type: Western Australia: $8.3 \mathrm{~km}$ from Norseman to Esperance road on Peak Charles road (3246'S, 12127'E), K. Hill 2316, L.A.S. Johnson E D. Blaxell, 8 Nov 1986 (holo NSW; iso BRI, CANB, K, MO, PERTH).

Tree to $12 \mathrm{~m}$ tall. Bark persistent on lower trunk (to $2-4 \mathrm{~m}$ ), shortly fibrous-flaky, grey or grey-brown; smooth white or pale grey above. Seedling leaves crowded and spiral for many nodes, dull grey-green, linear, sessile, to $1.5 \mathrm{~cm}$ long, $0.2 \mathrm{~cm}$ wide. Juvenile leaves disjunct, dull grey-green, similifacial, linear to lanceolate, to $7 \mathrm{~cm}$ long, $0.8 \mathrm{~cm}$ wide. Adult leaves disjunct, similifacial, linear to lanceolate, very glossy, bright green, 5-12 cm long, 0.6-1.2 cm wide; petioles $0.8-1.5 \mathrm{~cm}$ long. Lateral veins moderately spaced, \pm regular, at $30^{\circ}-50^{\circ}$ to midrib; reticulum even, \pm obscure; oil glands large, densely, packed; intramarginal vein continuous, \pm obscure, $<1 \mathrm{~mm}$ from margin. Inflorescences simple, axillary; umbellasters 7-11- flowered. Peduncles terete, 4-18 $\mathrm{mm}$ long. Pedicels terete, $2-6 \mathrm{~mm}$ long. Mature buds ovoid to fusiform, 5-7 mm long, 2.5-3 mm diam. Calyptra hemispherical to conical, rounded, obtuse or acute, 1-2 times as long as hypanthium. Fruits globular to ovoid, sometimes truncate, 3-4- locular, 4-5 mm long, 4-5 mm diam. Calyptra scar and stemonophore continuous, flat or slightly depressed, $0.2-0.3 \mathrm{~mm}$ wide. Disc depressed at ca $45-60^{\circ}$, c. $1 \mathrm{~mm}$ wide. Valves narrowly triangular, long-apiculate with persistent style remnants, basally deeply enclosed, apically vertically exserted. Seeds dull, grey-brown, \pm ellipsoidal, regularly shallowly reticulate (almost smooth), $0.75-1 \mathrm{~mm}$ long; hilum ventral. Chaff pale orange-brown. (Fig. 4).

Distinguished from the related taxa E. oleosa and E. longicornis by the small, narrow leaves and the small buds and fruits. It has been confused in Western Australia, apparently because of the small fruits, with the very different Salmon Gum, E. salmonophloia. The latter is separated from the Sociales at the series level by the glossy and wholly smooth bark, the regularly inflexed filaments with subglobular anthers and large connectives, the broad, long-petiolate, disjunct juvenile leaves and the highly glossy adult leaves with closely reticulate venation.

Known from widely scattered stands on sandy or loamy, somewhat calcareous soils, east of Bodallin, east of Hyden, in the area around Peak Charles, and east of Norseman (Fig. 2).

A locally frequent species, in low woodland with a variety of other tree species such as E. salubris, E. urna and E. valens. A mallee collected somewhat to the north of this range may also belong to this species, but requires further assessment $(27.4 \mathrm{~km}$ east of Yellowdine on highway, K.D. Hill 2619 \& L.A.S. Johnson, 26 Nov 1986, NSW, PERTH). 

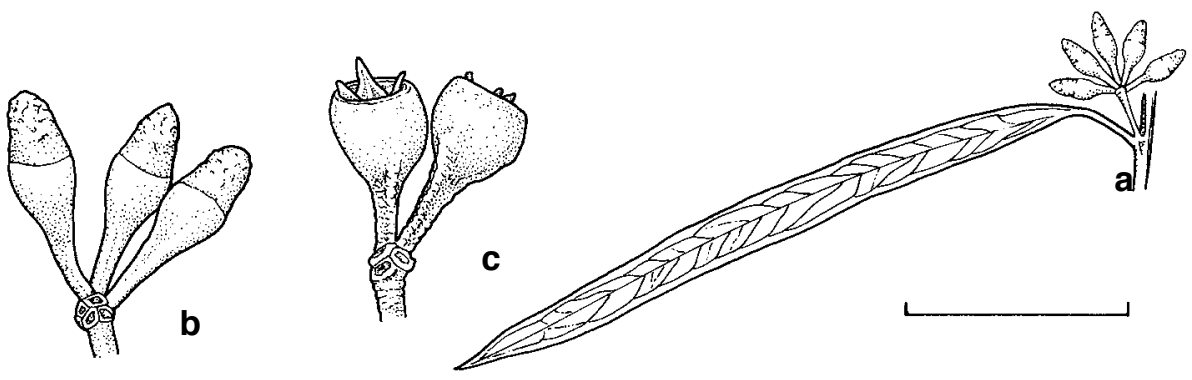

Fig. 4. E. delicata. $\mathbf{a}$, adult leaves, inflorescences and buds. $\mathbf{b}$, inflorescence and buds. $\mathbf{c}$, inflorescence and fruits. (from Hill 2335). Scale bar: $\mathrm{a}=3 \mathrm{~cm} ; \mathrm{b}, \mathrm{c}=1 \mathrm{~cm}$.

The epithet is from the Latin delicatus, dainty, in reference to the small buds and fruits.

Conservation status: not considered to be at risk.

Selected specimens (from 12 examined): Western Australia: $5.9 \mathrm{~km}$ E of Bodallin, Brooker 8058, 7 Apr 1983 (CANB, NSW); 69.5 km E of Norseman, Brooker 10169, 10170, 6 Mar 1989 (CANB, AD, CANB, MEL, NSW, PERTH); $3.6 \mathrm{~km}$ from end of made road up Fields road to north, Brooker 9526, 9527, 8 Nov 1986 (CANB, NSW); 7.6 km E of Cross Roads, E of Hyden, Brooker 10067, 24 Aug 1988 (CANB, NSW); $18.8 \mathrm{~km}$ N of Rollonds road on Fields road, Hill 2313, Johnson \& Blaxell, 7 Nov 1986 (NSW, CANB, MEL, PERTH); $2.3 \mathrm{~km}$ past Fields road (5 ways) on Ravensthorpe track, Hill 2335, Johnson \& Blaxell, 8 Nov 1986 (NSW, CANB, MEL, PERTH).

\section{Subseries Grasbyanosae}

Subseries defined as follows: juvenile leaves lanceolate, petiolate, opposite, becoming disjunct; adult leaves glossy to semiglossy; calyptra rounded to acute, not rostrate; filaments variably flexed in bud, with outer filaments erect and inner filaments regularly inflexed; style tip inserted into calyptra.

This group differs from the Longicornosae primarily in the opposite rather than spiral juvenile leaves. Eight species are included, although two rather coherent groups may be recognised, each with a distinct and different geographic range (species 5 to 8 and 9 to 12; Figs. 6 \& 9). Although no clear synapomorphies are evident for either group, synapomorphies for the broader subseries are not strong, and further study is required to properly evaluate relationships in this rather diverse group.

Subseries Grasbyanosae ranges from North-West Cape south into the Northern Wheatbelt in Western Australia, and east into the Great Victoria Desert in northwestern South Australia.

5. Eucalyptus grasbyi Maiden \& Blakely, Crit. Revis. Eucalyptus 8: 40 (1929).

Type: Western Australia: Lake Barlee, F. Fraser through W.G. Grasby (holo NSW 58886).

[Eucalyptus sp. M, Brooker \& Kleinig (1990)]

Mallee to $7 \mathrm{~m}$ tall, sometimes a small tree to $8 \mathrm{~m}$ tall. Bark persistent over lower $1 / 2$ or less, shortly fibrous-flaky, grey or grey-brown; smooth pale brown or grey above. Seedling leaves opposite for 3-5 nodes, sessile. Juvenile leaves disjunct, similifacial, lanceolate to ovate. Adult leaves disjunct, similifacial, lanceolate to broad-lanceolate, 
very glossy, bright green, 4-10 cm long, $0.9-2.6 \mathrm{~cm}$ wide; petioles to $2.0 \mathrm{~cm}$ long. Lateral veins moderately spaced, \pm regular, at $30^{\circ}-50^{\circ}$ to midrib; reticulum even, \pm obscure; oil glands large, densely packed; intramarginal vein continuous, \pm obscure, $<1 \mathrm{~mm}$ from margin. Inflorescences simple, axillary; umbellasters 11- or more flowered. Peduncles terete, 7-23 mm long. Pedicels terete, 4-10 mm long. Mature buds ovoid to fusiform, 7-10 mm long, 3-4 mm diam. Calyptra conical, acute or obtuse, 1.5-3 times as long as hypanthium. Fruits globular-truncate, to ovoid-truncate 3- rarely 4- locular, 4-6 mm long, 4-6 mm diam. Calyptra scar and stemonophore

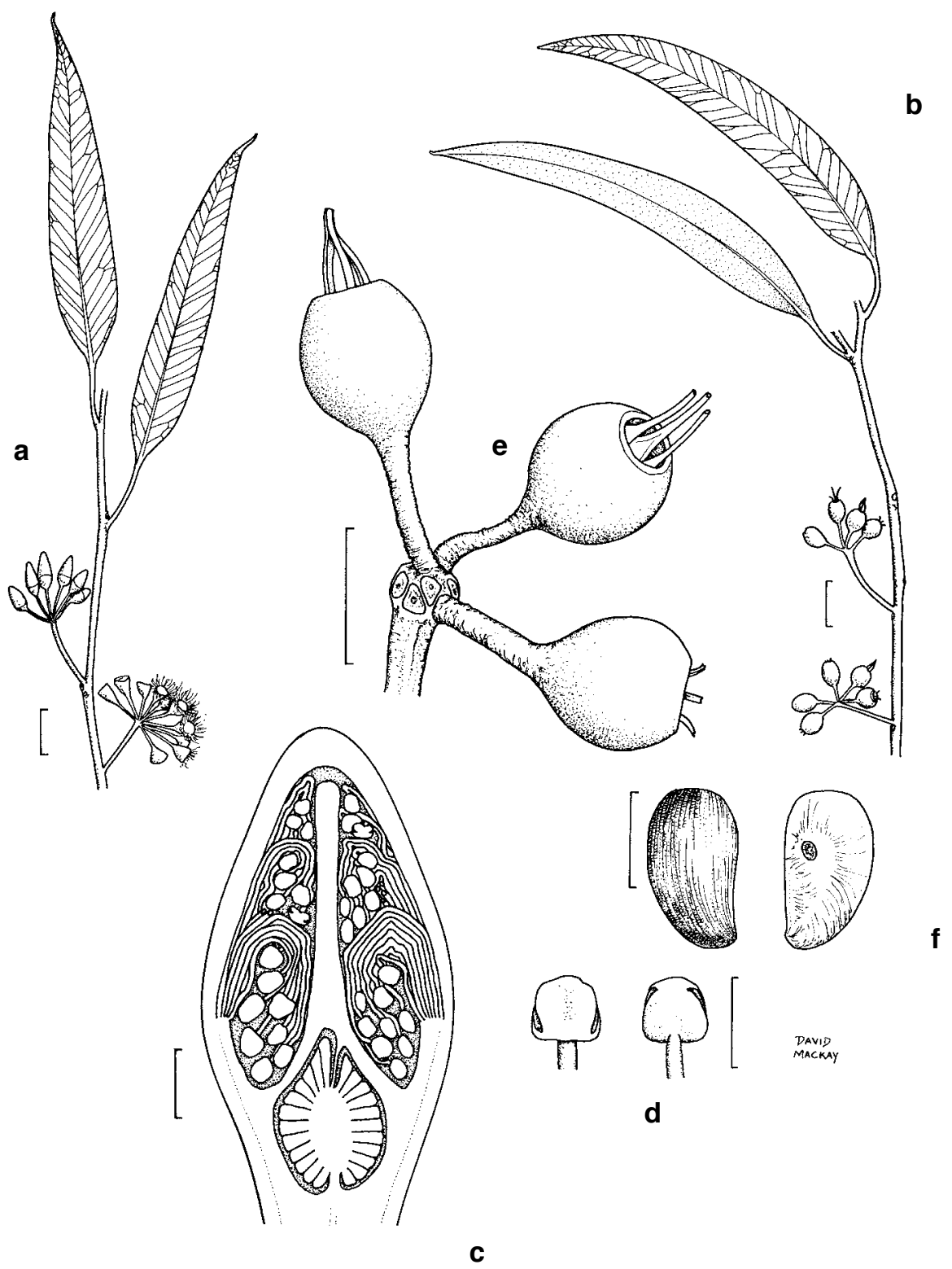

Fig. 5. E. grasbyi. a, adult leaves, inflorescences, buds and flowers. $\mathbf{b}$, adult leaves, inflorescences and fruits. $\mathbf{c}$, transverse section of bud. $\mathbf{d}$, anther. $\mathbf{e}$, inflorescence and fruits. $\mathbf{f}$, seed (a, c, d from Morrison s.n., b, e, f from Hill 521). Scale bar: $\mathrm{a}, \mathrm{b}=1 \mathrm{~cm} ; \mathrm{c}, \mathrm{f}=1 \mathrm{~mm} ; \mathrm{d}=0.5 \mathrm{~mm}$; $=5 \mathrm{~mm}$. 
continuous, flat or slightly depressed, $0.2-0.4 \mathrm{~mm}$ wide. Disc vertically depressed, c. $1 \mathrm{~mm}$ wide. Valves narrowly triangular, basally deeply enclosed, apically vertically exserted, with persistent style remnants. Seeds dull, dark grey-brown, irregularly flattened, \pm elliptical, regularly shallowly reticulate (almost smooth); hilum ventral. Chaff pale orange-brown. (Fig. 5).

E. grasbyi differs from E. eremicola in the thinner, longer peduncles and pedicels, the longer style and valve tips and the larger anthers.

A widely distributed and locally abundant species in the Goldfields region of Western Australia, from Kookynie district to south of Norseman (around Kumarl), east to around Karonie and west to between Southern Cross and Lake Barlee (Fig. 6). It grows in mallee shrublands on red loamy soils, along water courses in the north of the range, spreading to a variety of habitats further south.

This taxon has been widely regarded as part of E. longicornis (Gardner 1931, Gardner \& Watson 1950, Pryor \& Johnson 1971, Chippendale 1973). It is, however, clearly different in juvenile leaf morphology, and placed by this difference in a different subseries. In the absence of juvenile leaves, it is distinguished from E. longicornis in having more regular and more distinct leaf venation with the intramarginal vein nearer the leaf margin, smaller buds and fruits with longer and more slender peduncles and pedicels, longer and more slender filaments and smaller anthers, and in general a mallee habit compared to the tree habit of E. longicornis.

Conservation status: not considered to be at risk.

Selected specimens (from 51 examined): Western Australia: 0.2 miles [0.3 km] (R) of Eyre Highway, 4.2 miles [6.7 km] E of Norseman, Baker 56, 13 Nov 1970 (CANB, NSW); 24.5 miles [39.2 km] S of Norseman, Baker 62, 13 Nov 1970 (CANB, NSW); $44.5 \mathrm{~km} \mathrm{~S}$ of Widgiemooltha, Brooker 6411, 21 Aug 1979 (CANB, NSW); $27 \mathrm{~km} \mathrm{~S}$ of Number 5 Well on Sandstone to Menzies road, Brooker 9660, 23 June 1987 (CANB, NSW); 27 km from Kurnalpi to Pinjin, Brooker 9666, 24 June 1987 (CANB, NSW); 2.7 miles [4.3 km] NW of Widgiemooltha, Chippendale 143, 11 Mar 1967 (CANB, NSW); 7 km NNE of Norseman, Jimberlana Hill, Crisp 5638, 1 Feb 1979 (CANB, NSW, PERTH); 36.4 km S of Malcolm on track to Kookynie, Hill 521, Johnson, Blaxell \& Brooker, 4 Nov 1983 (NSW, CANB, PERTH); $7.2 \mathrm{~km}$ SW of Kookynie on rd to Menzies, Hill 524, Johnson, Blaxell \& Brooker, 4 Nov 1983 (NSW, CANB, PERTH); $4.2 \mathrm{~km} \mathrm{~S}$ of Menzies on hwy, Hill 540, Johnson, Blaxell \& Brooker, 4 Nov 1983 (NSW, CANB, PERTH); $51.7 \mathrm{~km}$ E of Karonie along railway, Hill 568, Johnson, Blaxell, Brooker \& Hopper, 5 Nov 1983 (NSW, CANB, PERTH); $37.4 \mathrm{~km} \mathrm{~S}$ of Coolgardie on hwy, Hill 578, Johnson Blaxell, Brooker \& Hopper, 6 Nov 1983 (NSW, CANB, PERTH); $8.8 \mathrm{~km} \mathrm{~N}$ of Hyden to Norseman track along Mt Day track, turning off $123 \mathrm{~km} \mathrm{~W}$ of Norseman to Coolgardie rd, Hill 625, Johnson, Blaxell Brooker \& Hopper, 7 Nov 1983 (NSW, CANB, PERTH); $26.7 \mathrm{~km}$ E of Norseman on hwy, Hill 678, 679 \& Blaxell, 14 Nov 1983 (NSW, CANB, PERTH); $22.7 \mathrm{~km}$ south of Lake Barlee homestead on Diemals road, Hill 2607 \& Johnson, 25 Nov 1986 (NSW, CANB, K, MEL, PERTH); $15.3 \mathrm{~km} \mathrm{~N}$ of Ora Banda turnoff towards Callion, Hill 2647 \& Johnson, 28 Nov 1986 (NSW, PERTH); $87.5 \mathrm{~km} \mathrm{~S}$ of PNC road on track to Zanthus, Hill 2692 \& Johnson, 30 Nov 1986 (NSW, PERTH); $14.7 \mathrm{~km} \mathrm{~W}$ of Coolgardie to Norseman rd on Hyden track, Hill 2843, 25 Aug 1988 (NSW); ca. 3 m [4.8 km] S of Dundas (ca. 24 m [38.4 km] S of Norseman), Johnson W 183, 18 Dec 1960 (NSW).

6. Eucalyptus eremicola Boomsma, SouthAustral. Naturalist 50 (1): 28 (1975), Fig. 1.

Type: South Australia: $125 \mathrm{~km}$ E. of Serpentine Lake, Victoria Desert, 38 36'S, $130^{\circ} 22^{\prime} \mathrm{E}$, J. Johnson, 28 June 1967 (holo AD 93749165).

Mallee. Adult leaves intermediate width (length:breadth $=4-8: 1$ ), very glossy, green or yellow-green. Oil glands moderately dense. Peduncles medium (4-11 mm). Pedicels medium (2-5 mm). Buds medium (6-9 mm long, 3-4 mm diam.). Calyptra conical, acute, c. $2 \times$ hypanthium. Fruits medium (4-6 $\times 4-6 \mathrm{~mm})$.

Widely distributed but scattered and sporadic, on red aeolian desert dunes, almost throughout the Great Victoria Desert (Fig. 6). 


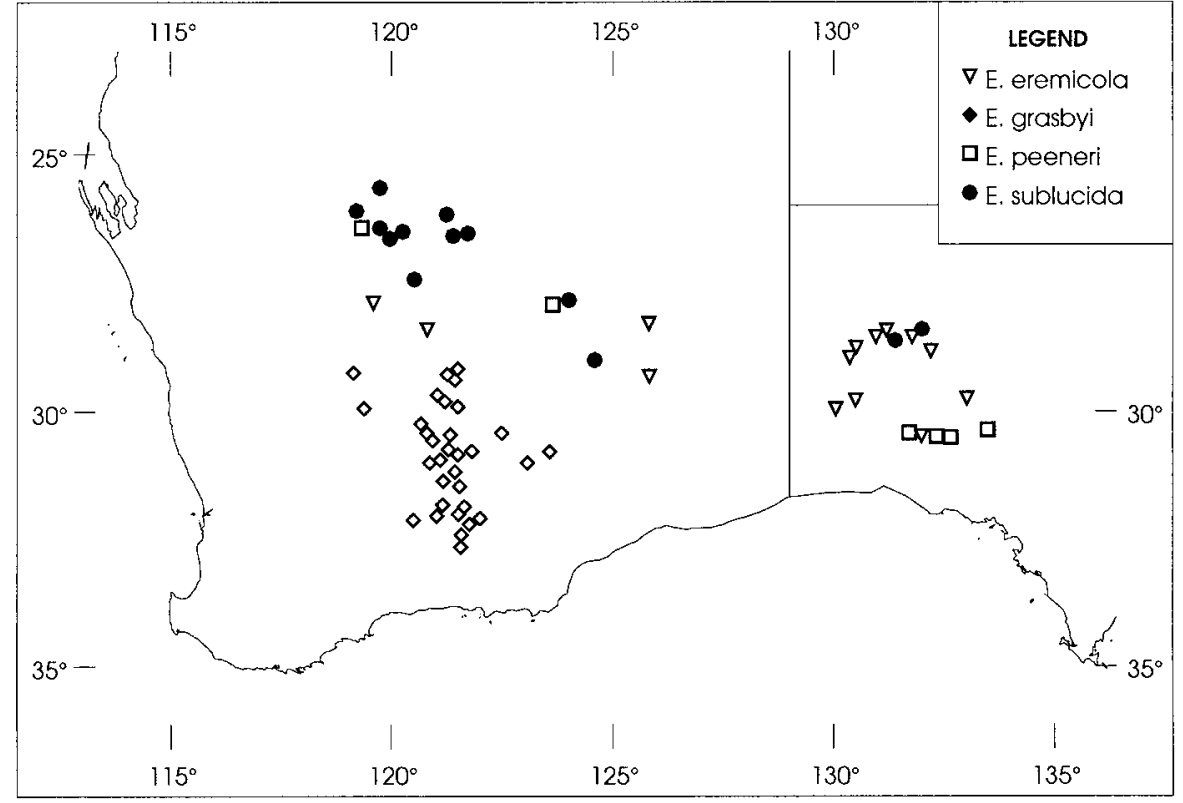

Fig. 6. Distribution of E. eremicola, E. grasby, E. peeneri and E. sublucida.

Conservation status: not considered to be at risk.

7. Eucalyptus sublucida L.A.S. Johnson E K.D. Hill, sp. nov.

$\mathrm{Ab}$ E. peeneri distinguitur: folia gracilius semilucida sed subcaerulea et subtiliter maculata, pedunculi et pedicelli majores et graciliores, fructus minores aliquanto plus elongati.

Type: Western Australia: $18 \mathrm{~km} \mathrm{~S}$ of Albion Downs turn-off on Leonora to Wiluna Rd, (2726'S, $\left.120^{\circ} 31^{\prime} E\right)$, K.D. Hill 519, L.A.S. Johnson, D.F. Blaxell E M.I.H. Brooker, 3 Nov 1983 (holo NSW; iso AD, CANB, K, PERTH).

[Eucalyptus sp. O, Brooker \& Kleinig (1990)]

Spreading mallee to $6 \mathrm{~m}$ tall. Bark persistent over lower 2-3 m, shortly fibrousflaky, grey-brown; smooth grey-brown above. Adult leaves disjunct, linear to broad-lanceolate, similifacial, semi-glossy with a bluish sheen, $4-11 \mathrm{~cm}$ long, $0.7-1.4 \mathrm{~cm}$ wide; petioles to $1.3 \mathrm{~cm}$ long; lateral veins moderately spaced, \pm regular, at $30^{\circ}-45^{\circ}$ to mid-rib; reticulum \pm obscure; oil glands large, densely spaced; intramarginal vein continuous, \pm obscure, c. $1 \mathrm{~mm}$ from margin. Inflorescences simple, sometimes paired, axillary; umbellasters 7-15-flowered; peduncles terete, 3-13 mm long; pedicels terete, 1-4 mm long. Mature buds ovoid; calyptra conical, acute, \pm as long as hypanthium. Fruits globular, 3-locular, 4-6 mm long, 4-6 mm diam.; calyptra scar and stemonophore continuous, $<0.2 \mathrm{~mm}$ wide; disc curved, flat or depressed to ultimately vertically depressed, $1-1.5 \mathrm{~mm}$ wide; valves narrowly triangular, basally deeply enclosed, apically vertically exserted, with persistent style remnants. Seeds dull, dark brown, irregularly flattened, \pm elliptical, regularly shallowly reticulate (almost smooth); hilum ventral; chaff pale orange-brown. (Fig. 7).

E. sublucida differs from E. peeneri in the finer, relatively narrower (ie with a higher length:breadth ratio) semi-glossy leaves with a bluish cast and finer cuticular spotting, the more slender peduncles and pedicels and the smaller, slightly more elongate fruits. 
It is distinguished within the Grasbyanosae by the following combination of characters: mallee; adult leaves relatively narrow (length:breadth $=3-6: 1$ ), semiglossy, with a bluish sheen; oil glands moderately dense; pedicels short (1-4 $\mathrm{mm})$; buds medium (7-9 mm long, 3-4 mm diam.); calyptra conical, acute, c. two times longer than hypanthium; fruits medium (4-6 × 4-6 mm), ovoid.

E. sublucida occurs in Western Australia, from the northern Great Victoria Desert west to the Meekatharra district, and also in South Australia, from the northern Great Victoria Desert, east through sand-ridge country almost to the Wilkinson Lakes area (Fig. 6).

Sporadically distributed and locally abundant on red 'desert' soils, apparently on loamy soils in the west of the range, graduating to sandy soils to the east, with Triodia in all cases.

The epithet is from the Latin lucidus, shining, with the Latin prefix sub-, somewhat, from the semiglossy foliage.

Conservation status: not considered to be at risk.

Selected specimens (from 18 examined): South Australia: $52.3 \mathrm{~km}$ E of Vokes Junction, Brooker 9432, 9433, 29 Aug 1986 (CANB, NSW); ca. $90 \mathrm{~km}$ west of Emu Junction (Emu Junction is ca. $225 \mathrm{~km}$ west of Mabel Creek Homestead), North West Plains, Donner 3897, 16 July 1972 (AD, NSW); 21 miles [33.6 km] W of Emu, Forde 482, 3 Sep 1956 (CANB, NSW).

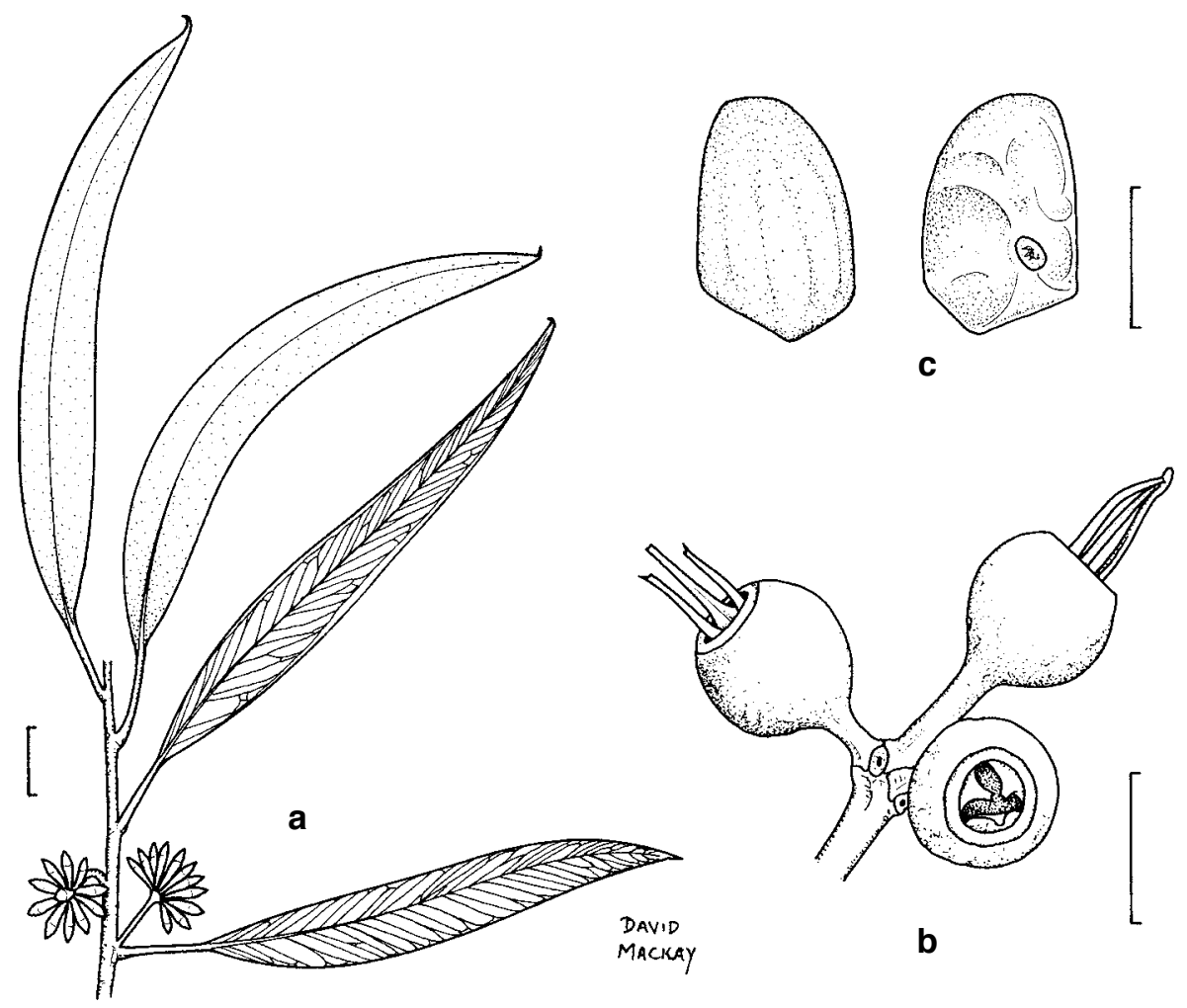

Fig. 7. E. sublucida. a, adult leaves, inflorescences and buds. $\mathbf{b}$, inflorescence and fruits. $\mathbf{c}$, seed (from Hill 519). Scale bar: $\mathrm{a}=1 \mathrm{~cm} ; \mathrm{b}=5 \mathrm{~mm} ; \mathrm{c}=1 \mathrm{~mm}$. 
Western Australia: southern end Lake Throssel, 58 miles [92.8 km] east Cosmo Newberry, Martin 3579, 25 Apr 1975 (UNSW, NSW); 6.3 km N of Wubin towards Perenjori, Brooker 7919, 11 Jan 1983 (CANB, NSW); $18 \mathrm{~km} \mathrm{~S}$ of Albion Downs t/o [turnoff] on Wiluna to Leonora road, Brooker 8333, 3 Nov 1983 (CANB, NSW); 76 km NW of airstrip, Great Victoria Desert, Brooker 8572, 13 May 1984 (CANB, NSW); $4.9 \mathrm{~km}$ N of Meekatharra to Wiluna road on Paroo track, Jarvie Well, Brooker 9239, 16 Apr 1986 (CANB, NSW); $11 \mathrm{~km} \mathrm{~N}$ of Wiluna on Cunyu road, Brooker 9242, 17 Apr 1986 (CANB, NSW); $203.6 \mathrm{~km} \mathrm{~W}$ of Carnegie towards Wiluna, Brooker 10718, 15 Apr 1991 (CANB, AD, NSW, PERTH); 132.9 km NW of Wiluna towards Great Northern Hwy, Brooker 10725, 16 Apr 1991 (CANB, AD, NSW, PERTH); 18 miles [28.8 km] west of Yelma, Carolin 5859, 25 July 1967 (NSW); $49.9 \mathrm{~km} \mathrm{~W}$ of Wiluna on rd to Meekatharra, Hill 508, Johnson, Blaxell \& Brooker, 2 Nov 1983 (NSW, CANB, PERTH); $23 \mathrm{~km} \mathrm{~W}$ of Wiluna on rd to Meekatharra, Hill 509, Johnson, Blaxell \& Brooker, 2 Nov 1983 (NSW, CANB, PERTH); south of Camel Well, Eremean Province, Speck 819, 14 Sep 1957 (CANB, NSW); 15 miles [24 km] E of Mooloogool Homestead, Eremean Province, Speck 1151, 8 Apr 1959 (CANB, NSW).

8. Eucalyptus peeneri (Blakely) Pryor \& Johnson ex Boomsma, J. Adelaide Bot. Gard. 1(6): 368 (1979).

Basionym: Eucalyptus oleosa F. Muell. var. peeneri Blakely, Key Eucalypts 270 (1934).

Type: South Australia: Barton (305, 133르), E. Ising 1372, Sep 1920 (lecto NSW; isolecto AD, CANB, G, K, PERTH, US; fide Boomsma 1979).

Mallee. Adult leaves relatively narrow (length:breadth $=4-7: 1$ ), dull. Oil glands moderately dense. Pedicels short (1-3 mm). Buds large (7-10 mm long, 3-4 mm diam.). Calyptra conical, acute, not beaked, c. $2 \times$ hypanthium. Fruits large $(5-7 \times 5-7 \mathrm{~mm})$, globular-truncate.

This taxon is characterised by coarse, dull leaves with coarse cuticular spotting, short and thick peduncles and pedicels, and short, truncate fruits.

Scattered and apparently nowhere common, from east of Meekatharra to near Wynbring, on red desert sand country (Fig. 6).

Conservation status: not known (3K).

\section{Eucalyptus ultima L.A.S. Johnson E K.D. Hill, sp. nov.}

$\mathrm{Ab}$ E. horiste distinguitur: cortex omnino laevis, folia semilucida, calyptra longior, fructus minores et plus globulares.

Type: Western Australia: Shothole Canyon, Cape Range, $\left(22^{\circ} 23^{\prime} \mathrm{S}, 114^{\circ} 01^{\prime} \mathrm{E}\right)$, M.I.H. Brooker 5692, 15 Apr 1977 (holo NSW; iso AD, CANB, MEL, PERTH).

Mallee to $4 \mathrm{~m}$ tall. Bark smooth to base, dull pale grey or pinkish-grey. Adult leaves disjunct, narrow-lanceolate to lanceolate, acuminate, similifacial, semi-glossy, green, 4-9 cm long, 0.5-1.5 cm wide; petiole to $0.9 \mathrm{~cm}$ long; lateral veins moderately spaced, \pm regular, \pm obscure, at $30^{\circ}-45^{\circ}$ to midrib; oil glands large, closely-spaced; intramarginal vein continuous, \pm obscure, $<1 \mathrm{~mm}$ from margin or at margin. Inflorescences simple, axillary, 11- or more flowered; peduncles terete, 4-9 mm long; pedicels terete, 1-4 mm long. Mature buds ovoid, sometimes apically elongate, 6-10 mm long, 2.5-3 mm diam.; calyptra conical, rounded to convex, 1-2.5 times as long as hypanthium. Fruits cup-shaped to globular-truncate, apically \pm narrowed, 3-locular, 4-5 mm long, 4-5 $\mathrm{mm}$ diam.; calyptra scar and stemonophore continuous, flat, c. $0.5 \mathrm{~mm}$ wide; disc vertically depressed, c. $1 \mathrm{~mm}$ wide; valves narrowly triangular, basally deeply enclosed, apically vertically exserted, with persistent style remnants. Seeds dull, grey-brown, \pm flattened, elliptical, shallowly reticulate (almost smooth); hilum ventral; chaff dark grey-brown. (Fig. 8). 
E. ultima is nearest to E. horistes, from which it differs in the wholly smooth bark, semiglossy leaves, longer calyptra and smaller, more globular fruits. E. kochii shares the narrow leaves of E. ultima, but has rough bark and elongated fruits.

Known only from skeletal soils on limestone on the Cape Range, Northwest Cape, where it is locally abundant (Fig. 9).

The epithet is from the Latin ultimus, farthest, most distant, in reference to the occurrence at the farthest extreme of the range of the subseries Grasbyanosae.

Conservation status: not considered to be at risk.

Selected specimens (from 12 examined): Western Australia: 2.3 miles [3.7 km] west of Exmouth road on Charles Knife road, Brooker 4571, 24 Apr 1974 (CANB, NSW); Charles Knife Road, Cape Range, George 10336, 8 Sep 1970 (PERTH, NSW); Charles Knife Rd, Cape Range National Park, George 14580, 3 May 1977 (PERTH, NSW); 3.5 km west of Exmouth road along Charles Knife road, $30 \mathrm{~km}$ south of Exmouth, Hill 409, 410 Johnson Blaxell ,Brooker \& Edgecombe, 28 Oct 1983 (NSW); 9.6 $\mathrm{km} \mathrm{W}$ of Shothole Canyon Road, $16 \mathrm{~km}$ S of Exmouth, Kenneally 7339, 29 July 1980 (PERTH, NSW); Cape Range, $16.9 \mathrm{~km}$ SW of Learmonth on track to west coast, Johnson 9364 \& Briggs, 7 Aug 1991 (NSW, BRI, CANB, DNA, PERTH); Cape Range $11 \mathrm{~km} \mathrm{~W}$ of Learmonth Airforce Base on track to ocean, Johnson 9367 \& Briggs, 7 Aug 1991 (NSW).

10. Eucalyptus horistes L.A.S. Johnson \& K.D. Hill, Fl. Australia 19: 509 (1988).

Type: Western Australia: $15.9 \mathrm{~km} \mathrm{~N}$ of Binnu on Highway 1, Western Australia (275'ㄴ, 114²4'E), K. Hill 389, L. Johnson, D. Blaxell \& I. Brooker, 27.10.1983 (holo NSW; iso $\mathrm{AD}, \mathrm{CANB}, \mathrm{MEL}, \mathrm{PERTH})$.

Mallee. Bark persistent on lower trunk. Adult leaves relatively narrow (length:breadth = 6-10:1), glossy. Oil glands dense. Peduncles medium (7-12 mm). Pedicels short (1-4 mm). Buds medium (7-9 mm long, 3-4 mm diam.). Calyptra conical, acute to obtuse, slightly longer than hypanthium. Fruits medium to large $(5-8 \times 5-8 \mathrm{~mm})$, elongate ovoid-truncate.

E. horistes differs from E. ultima in the rough bark, glossy leaves, short calyptra and larger, longer fruits. The leaves are consistently broader and glossier than those of E. kochii, and the calyptra longer and more pointed than that of E. plenissima.

Locally frequent on lateritic or sandy country, from the Murchison River to near Coorow, inland as far as Pindar. A single record from near Wiluna (Fig. 9) agrees with the species but is from a much more easterly locality in different country; the possibility of a mislocation suggests itself.

Conservation status: not considered to be at risk.

11. Eucalyptus kochii Maiden \& Blakely, Crit. Revis. Eucalyptus 8: 41 (1929).

Type: Western Australia: Watheroo rabbit fence, c. 60 miles E. of Watheroo, M. Koch 1608, Sep 1905 (lectotype NSW, here designated). Illustrated by Maiden (C.R. 2, plate 66, fig. 2 (1912)), as E. oleosa. This specimen comprises several separate pieces, with adult leaves, buds, flowers and fruits, and is the most complete of the Syntypes. The type citation was: 'It is known only from Watheroo rabbit fence (Max Koch. Nos. 1608, 1990, 1990a, September, 1905).'

= E. oleosa F. Muell. var. kochii C. Gardner, J. \& Proc. Roy. Soc. Western Australia 34: 78 (1948).

Type: Western Australia: Rabbit-proof fence, 25 miles [40 km] E. from Dalwallinu, C.A. Gardner 8524, (holo PERTH). Although Gardner based his variety on E. kochii Maiden \& Blakely and used their epithet, he published it as a 'var. nov.' and cited a different type. The author citation is hence as above, and does not acknowledge 

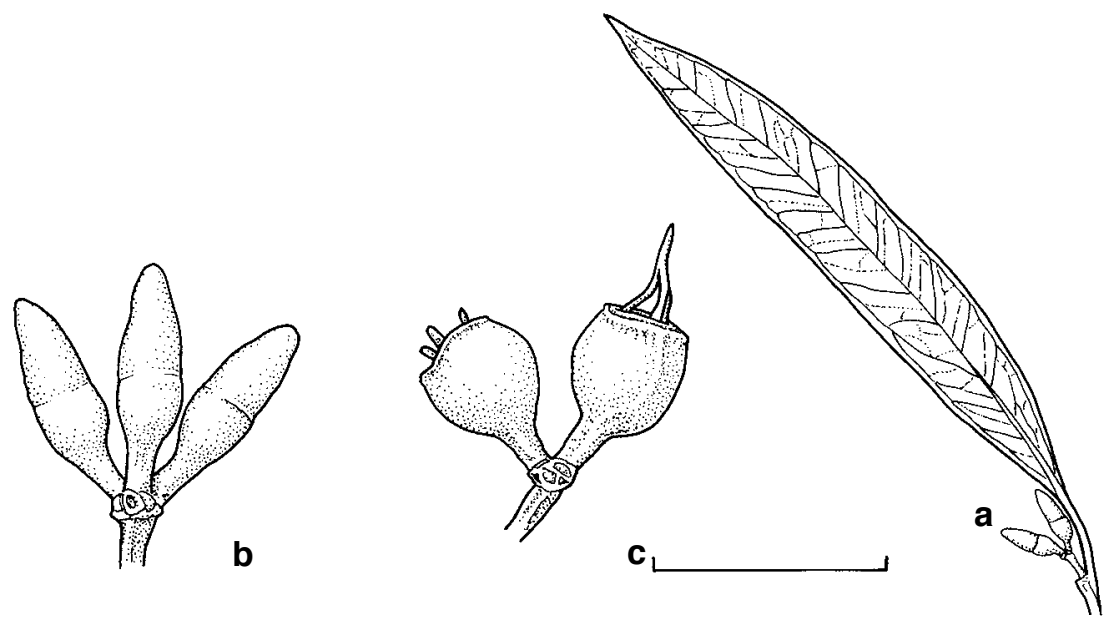

Fig. 8. E. ultima. a, adult leaves, inflorescence and buds. $\mathbf{b}$, inflorescence and buds. $\mathbf{c}$, inflorescence and fruits. (from Brooker 5692). Scale bar: $\mathrm{a}=3 \mathrm{~cm} ; \mathrm{b}, \mathrm{c}=1 \mathrm{~cm}$.

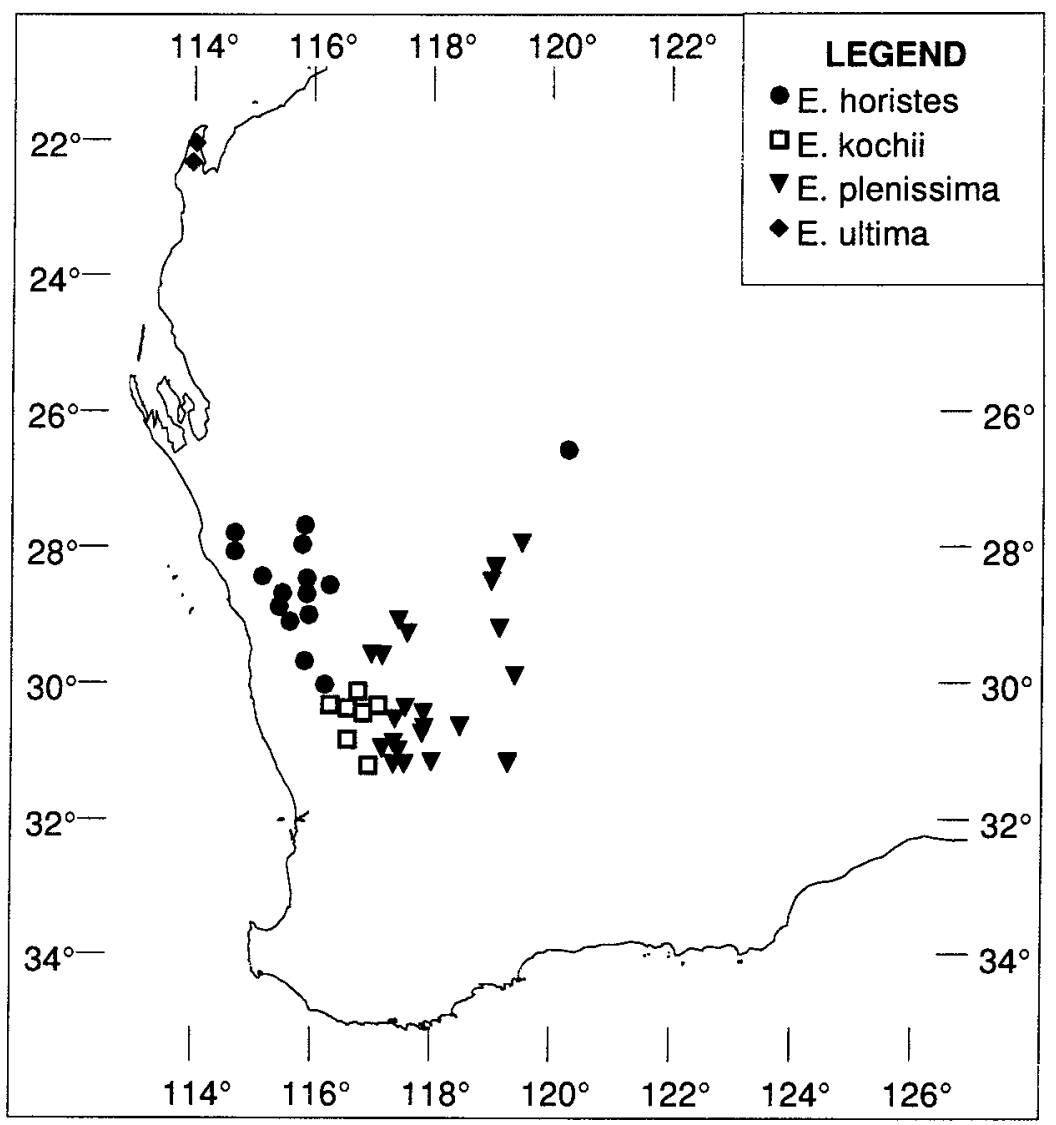

Fig. 9. Distribution of E. horistes, E. kochii, E. plenissima and E. ultima. 
Maiden \& Blakely. Gardner also included Koch collections probably representing part of Maiden \& Blakely's type material in his specimen citation.

Tree or mallee. Bark persistent on trunk and lower branches. Adult leaves very narrow (length:breadth $=10-16: 1$ ), dull to slightly glossy. Oil glands dense. Pedicels short (1-4 mm), thick. Buds medium (5-8 mm long, 3-4 mm diam.). Calyptra conical, acute to rounded, 1-2 $\times$ hypanthium. Fruits medium (5-8 long, 5-7 mm diam.), elongate ovoid-truncate or urceolate.

E. kochii differs from E. horistes in the narrower, duller leaves, longer fruits and more extensive rough bark, and from E. plenissima in the conical rather than rounded calyptra and the dull leaves.

Restricted in distribution but locally frequent on red loams and sandy loams, in the Gunyidi-Wubin-Pithara-Kalannie area (Fig. 9).

Conservation status: not considered to be at risk.

12. Eucalyptus plenissima (C. Gardner) Brooker, Austral. Forest Research 7: 65 (1976), fig. 1.

Basionym: Eucalyptus oleosa F. Muell. var. plenissima C. Gardner, J. \& Proc. Roy. Soc. Western Australia 34: 79 (1948).

Type: Western Australia: between Beacon and Wialki, in sandy soil, Gardner 8532 (holo PERTH).

Tree or mallee. Bark persistent on lower trunk. Adult leaves relatively broad (length: breadth $=4-8: 1)$, glossy. Oil glands dense. Pedicels short (1-3 mm). Buds medium (6-8 $\mathrm{mm}$ long, 3-4 mm diam.). Calyptra hemispherical, shorter than hypanthium. Fruits medium to large (5-8 $\mathrm{mm}$ long, 5-7 mm diam.), elongate ovoid-truncate or urceolate.

E. plenissima is clearly distinguished in the subseries by the glossy leaves, the short, hemispherical calyptra and the \pm urceolate fruits.

Locally frequent on red desert loams and sandy loams, in the area bounded by Sandstone, Mongers Lake, Dowerin and Nungarin (Fig. 9). Plants occurring to the east of this range with a more completely persistent bark and somewhat narrower leaves may belong to this taxon, but require further assessment $(64 \mathrm{~km} \mathrm{~W}$ of Boorabin Rock, Brooker 10890, 21 Nov 1991; CANB, AD, NSW, PERTH).

Conservation status: not considered to be at risk.

\section{Subseries Aspersosae}

Subseries defined as follows: juveniles leaves opposite for many nodes, sessile, narrowly elliptical, dull blue-grey, minutely decurrent; adult leaves semi-glossy; inflorescences up to 15-flowered; calyptra rostrate; filaments variably flexed in bud, mostly regularly inflexed with a few outer filaments erect; style tip inserted into calyptra.

A monospecific group with a single rare species restricted to Jarrah forest country in Western Australia.

\section{Eucalyptus aspersa Brooker \& Hopper, Nuytsia 9: 28 (1993).}

Type: Western Australia: $2 \mathrm{~km}$ N of Serpentine River along Albany Highway, $32^{\circ} 31^{\prime} \mathrm{S}$ $116^{\circ}$ 21'E, M.I.H. Brooker 9047, 9 Oct 1985 (holo PERTH; iso CANB, NSW).

The single species in the subseries, distinguishing characters as for the subseries.

Restricted and localised, on skeletal soils on laterite in openings in Jarrah forest, in the area between west of Brookton and Mt Saddleback, Dale District (Fig. 10). A 
single old record exists from Broome Hill (Genoni, Sep 1936, NSW), but this is a quite different environment, and the record has not been recently substantiated. This must consequently be regarded as an error in labelling.

Conservation status: sporadic and in small populations. A code of $2 \mathrm{R}$ is appropriate.

\section{Subseries Socialosae}

Subseries defined as follows: juvenile leaves opposite, sessile, minutely decurrent for few nodes, becoming disjunct and subsessile; adult leaves dull; calyptra rostrate; filaments variably flexed in bud, mostly regularly inflexed with a few outer filaments erect; style tip inserted into calyptra.

A widely distributed and complex subseries of eight species, with a distribution closely paralleling that of subseries Longicornosae.

14. Eucalyptus socialis F. Muell. ex Miq., Ned. Kruidk. Arch. 4: 132 (1856).

Type: South Australia: Pine Forest, Gawler Town [sic], Dr Behr Jan. 1849 (lecto MEL, isolecto NSW, here designated). The type citation was 'In sylva Pine-forest prope Gawler-town; frequenter ultra Salts-creek, ubi plagas sterilissimas tegit et illa fruticeta Scrub dicta ex parte format. Fl. vere et nestate.' Behr's collections from this area included both E. socialis and E. oleosa, mixed collections of which were the basis for E. turbinata Behr et F. Muell. ex Miq., discussed under E. oleosa.

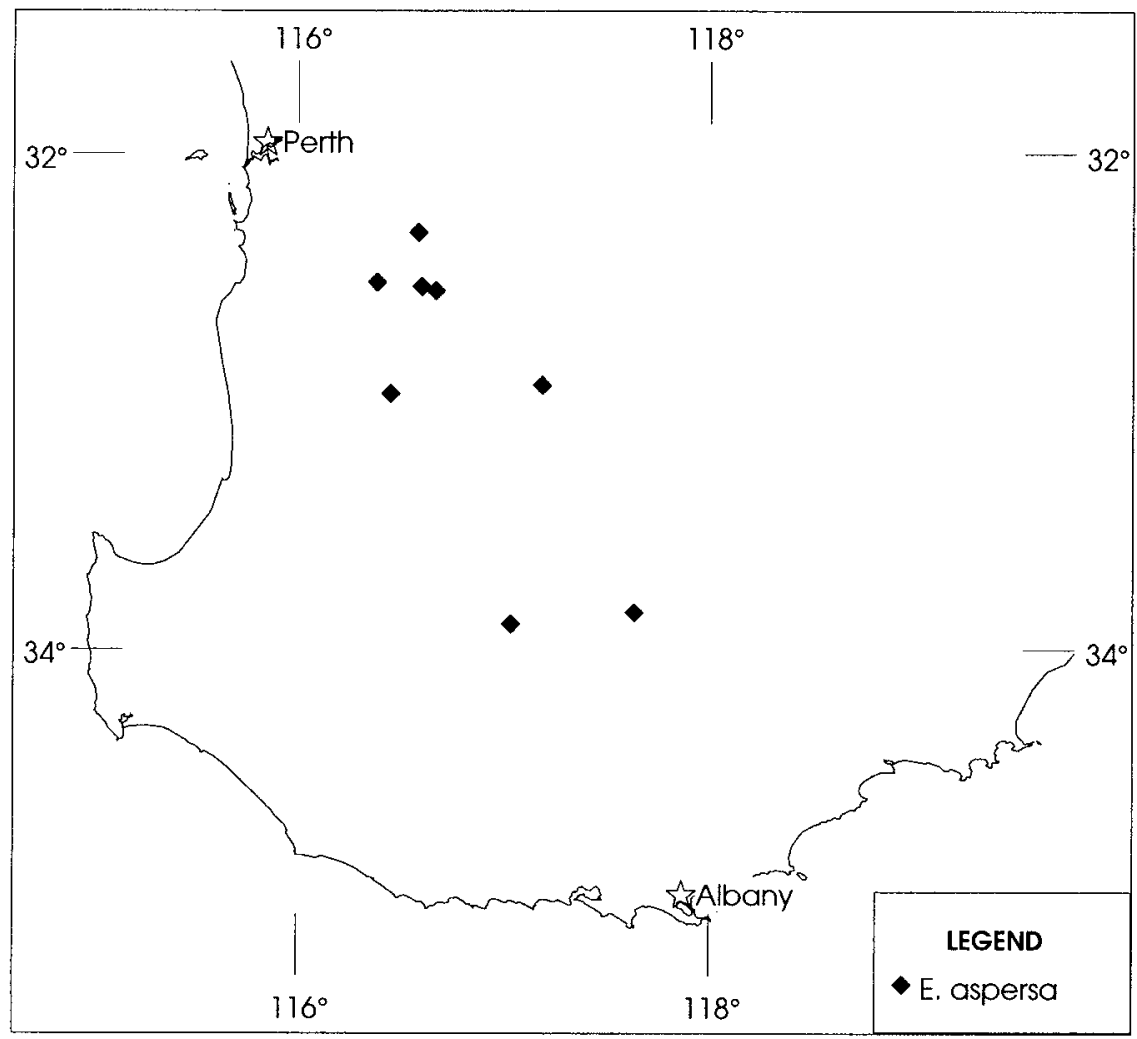

Fig. 10. Distribution of E. aspersa. 
Maiden (C.R. 2: 183, legend to plate 65, fig. 17 stated that a Mueller collection from 'versus flum. Murray' was the type (in effect designating this specimen the Lectotype). Details of this specimen were not cited, however, and it cannot stand as a Lectotype.

Bentham (1867) included E. socialis in E. oleosa, and Maiden (C.R. 2: 167) included it in E. oleosa var. glauca, although he made no mention of E. socialis when describing E. transcontinentalis, based on his var. glauca. Blakely (1934) then recognised E. socialis as a distinct taxon.

Erect mallee. Bark mostly persistent on lower trunk. Adult leaves disjunct. Buds and fruits small $(9-13 \times 3-4$ and $4-7 \times 4-7 \mathrm{~mm})$, non-glaucous. Flowers cream. Calyptra $>1.5 \times$ hypanthium, elongate-rostrate. Fruits globular.

Widespread and abundant through mallee communities of New South Wales, Victoria and eastern South Australia, as far west as eastern Eyre Peninsula and north to Oodnadatta (Fig. 11).

Conservation status: not considered to be at risk.

15. Eucalyptus yalatensis Boomsma, S. Austral. Naturalist 50 (1): 29 (1975), fig. 2.

Type: South Australia: 17 km SSE. Yalata, 313'ㄴ, 13158'E, B. Copley AD 96938251, 27 July 1969 (holo AD).

Mallee, often sprawling and decumbent. Bark persistent almost throughout. Adult leaves disjunct. Buds and fruits small (to $10 \times 4$ and $6 \times 6 \mathrm{~mm}$ ), non-glaucous. Flowers cream. Fruits cup-shaped or conical, flat-topped.

Widespread and abundant on limestone to the west of the Nullarbor Plain, from Nullarbor Station almost to Balladonia, also in western and central Eyre Peninsula (Fig. 11).

16. Eucalyptus gillii Maiden, Crit. Revis. Eucalyptus 2: 77 (1910), Plate 67, Fig. 7.

Type: Umberatana, Flinders Range, far northern South Australia, W. Gill s.n., May 1907 (holo NSW; iso K, or possibly part of holo).

Adult leaves opposite, subsessile. Buds and fruits small (7-12 × $3-5$ and 4-6 × 4-6 mm), grey to glaucous. Flowers cream.

Locally dominant on skeletal soil on rocky slopes in the Northern Flinders Ranges (South Australia), with sporadic outliers in the Barrier Range in New South Wales (Fig. 11).

Conservation status: not considered to be at risk.

17. Eucalyptus eucentrica L.A.S. Johnson \& K.D. Hill, Telopea 4(2): 328 (1991).

Type: Northern Territory: $39.4 \mathrm{~km} \mathrm{~N}$ of Erldunda on Stuart Highway (24 $52^{\circ} \mathrm{S}$ $133^{\circ} 11^{\prime} \mathrm{E}$ ), K. Hill 858, L. Johnson $\mathcal{E}$ D. Benson, 10 July 1984 (holo NSW; iso BRI, DNA, CANB).

Distinguished from E. socialis F. Muell. ex Miq. by the larger adult leaves $(6-13 \times 1.4-3.4 \mathrm{~cm})$, the larger buds $(10-17 \times 4-5 \mathrm{~mm})$ and the larger fruits $(6-9 \times 6-9 \mathrm{~mm})$, and the yellow flowers (cream in E. socialis). E. yumbarrana Boomsma from southern South Australia is similar in flower colour, but coarser again in leaves (to $14 \mathrm{~cm}$ long), buds (5-7 mm diam.) and fruits (to $12 \mathrm{~mm}$ long).

Sporadic and locally abundant over a wide area in Central Australia (N.T., S.A. and W.A.), with isolated outlying populations in the Pilbara region of W.A. and in central Queensland (Fig. 11). 
A locally abundant species on a wide range of sites and substrates. Often on red sand with a calcareous horizon, in swale areas in dune systems, or on stony slopes, again with calcareous deposits in the soil.

Intergrading populations occur with E. yumbarrana (widespread from near Ooldea to the northwestern Eyre Peninsula). These in turn intergrade in a contact zone with E. socialis further east in northern Eyre Peninsula.

Conservation status: not considered to be at risk.

18. Eucalyptus vokesensis D. Nicolle $\mathcal{E}$ L.A.S. Johnson, sp. nov.

$\mathrm{Ab}$ E. yumbarrana distinguitur: folia, ramuli et alabastra glauca, fructus minores .

Type: South Australia: c. $130 \mathrm{~km} \mathrm{~N}$ of Cook along track to Vokes Corner, J.Z. Weber 6343, 19 August 1980 (holo AD; iso NSW).

Mallee to $8 \mathrm{~m}$ tall. Bark persistent on trunk and larger branches, grey, shortly fibrousflaky. Plant strongly glaucous. Juvenile leaves not seen. Adult leaves disjunct, ovate to elliptical, acute or acuminate, dull, $4.0-10.0 \mathrm{~cm}$ long, $1.5-4.5 \mathrm{~cm}$ wide; petioles terete to distinctly flattened, $1.5-2.5 \mathrm{~cm}$ long; lateral veins at c. $45^{\circ}$ to midrib, regular, moderately spaced; secondary reticulum open, somewhat degenerate; intramarginal vein distinct, 1-3 $\mathrm{mm}$ from margin. Umbellasters axillary, 7-flowered; peduncles terete, 7-22 mm long; pedicels terete, 2-10 $\mathrm{mm}$ long. Mature buds ovoid to elongate ovoid, apically tapered and \pm rostrate, $10-15 \mathrm{~mm}$ long, 5-7 mm diam.; calyptra narrowly conical, flared at base, 1-2 times longer than hypanthium, wider than hypanthium. Stamens all fertile; filaments variably flexed in bud, mostly

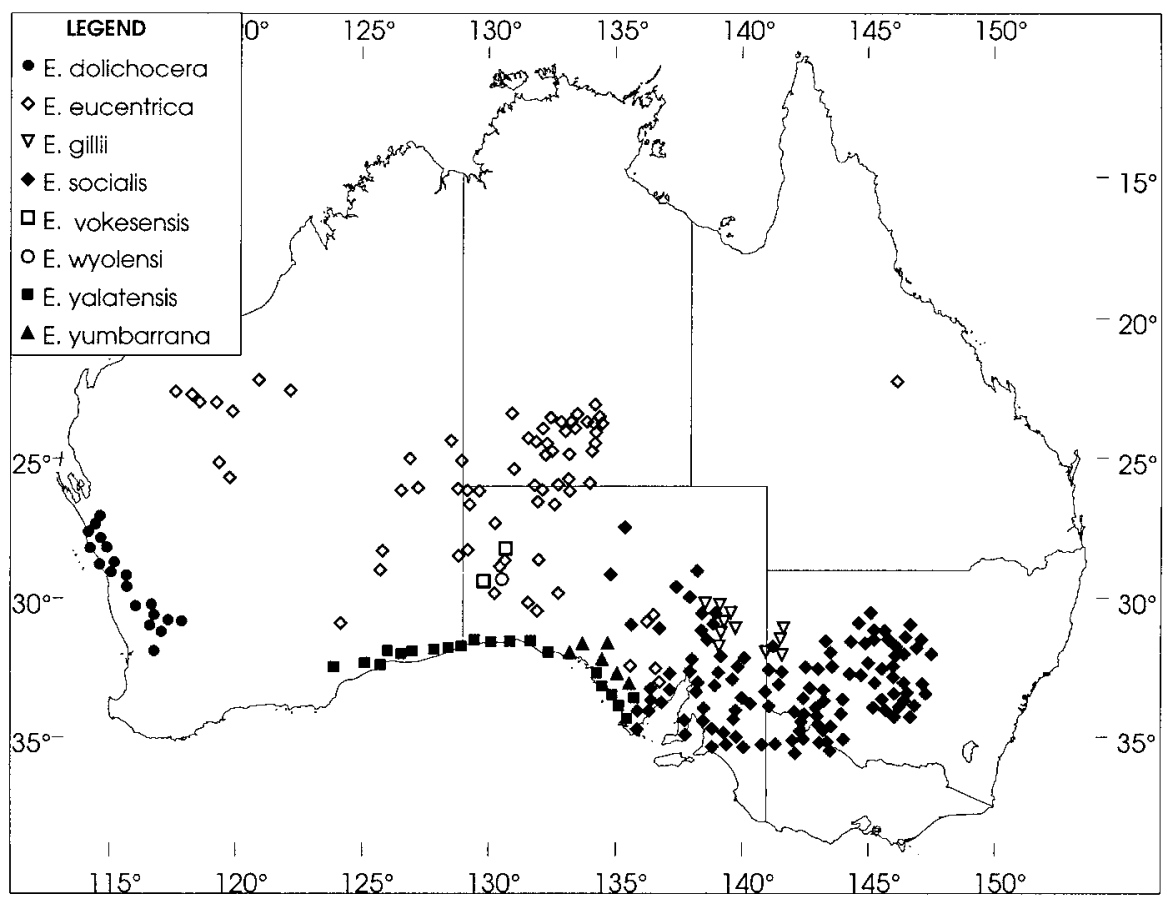

Fig. 11. Distribution of E. eucentrica,E. dolichocera, E. gillii, E. socialis, E. vokesensis, E. wyolensis, E. yalatensis and E. yumbarrana. 
regularly inflexed with a few outer filaments erect; anthers subglobular, \pm basifixed, versatile; connective gland large; cells divergent, dehiscing by short slits. Fruits cupshaped, apically constricted, 3-4-locular, 7-8 $\mathrm{mm}$ long, 7-8 $\mathrm{mm}$ diam.; calyptra scar \pm level, c. $0.5 \mathrm{~mm}$ wide; stemonophore somewhat depressed, c. $0.5 \mathrm{~mm}$ wide; disc level or depressed, 1-2 mm wide; valves deeply enclosed basally, acuminate tips vertically exserted, remnants of persistent style forming tips of valves. Seeds semi glossy, grey brown, rounded, finely and shallowly reticulate, 1-1.5 mm long; hilum ventral; chaff similar, smaller glossy pale brown.

This species in distinguished from E. yumbarrana primarily by the strong glaucousness of all parts. Buds and fruits are also generally smaller. Hybrids are recorded with E. canescens D. Nicolle, and one such hybrid was described as E. yumbarrana subsp. striata Boomsma (see appendix).

Restricted to desert sandhill country to the north of the Nullarbor Plain in South Australia (Fig. 11). Locally frequent in sandy swales with Acacia aneura.

Conservation status: not considered to be at risk.

Selected specimens (from 7 examined): South Australia: Vokes junction, Great Victoria Desert, Jackson 1379, 22 Aug 1980 (AD, NSW); main sand dune belt N of Cook on Cook-Vokes Hill Road 62930'42"E 13008'56"S, Nicolle 109, 5 Dec 1992 (AD); 34 km from Cook-Vokes Hill Road

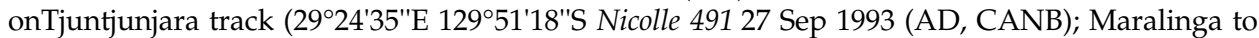
Oak Valley Road (2943'51"E 13105'09"S, Nicolle 150214 Sep 1995 (AD); Cook to Vokes Hill Road, ca. $135 \mathrm{~km}$ N of Cook, campsite just S of main set of dunes N of Nullarbor Plain, Symon 12234, 18 Aug 1980 (AD, NSW); Cook to Vokes Hill Road, $143 \mathrm{~km} \mathrm{~N}$ of Cook, N of the Nullarbor Plain, Symon 12257, 20 Aug 1980 (AD, CANB, NSW); Cook to Vokes Hill Road, ca. $145 \mathrm{~km}$ N of Cook, N of the Nullarbor Plain, Symon 12260, 20 Aug 1980 (AD, CANB, NSW); c. 130 km North of Cook along track Cook to Vokes Corner, Weber 6315, 6343, 19 Aug 1980 (AD, NSW).

19. Eucalyptus wyolensis Boomsma, J. Adelaide Bot. Gard. 10(1): 59 (1987).

Type: South Australia: $59 \mathrm{~km} \mathrm{~W}$ of Lake Maurice [south of Lake Wyola] (29 $25^{\prime} \mathrm{S}$, 130E), G. White 13, 27 Mar 1987 (holo AD; iso CANB, K, NSW).

Adult leaves opposite, subsessile. Buds and fruits strongly glaucous, large (9-15 × 4-6 and 6-9 × 6-10 mm). Flowers yellow.

Known from a limited area on red sandhill country in the Great Victoria Desert to the north of the Nullarbor Plain in South Australia (Fig. 11). Although morphologically similar to E. gillii, this species shares the yellow flower colour with the E. eucentricaE. vokesensis group, and the leaf morphologies would appear to be parallel developments.

Conservation status: not known (2-3K).

20. Eucalyptus yumbarrana Boomsma, J. Adelaide Bot. Gard. 1(6): 366, fig. 4 (1979).

Type: South Australia: Yumbarrana Conservation Park, $31^{\circ} 45^{\prime} \mathrm{S}, 133^{\circ} 35^{\prime} \mathrm{E}, \mathrm{T}$. Dennis s.n., 17 June 1977 (holo AD97726343; iso AD97726344).

Erect to sprawling mallee. Bark persistent on lower trunk. Adult leaves disjunct, broad-lanceolate. Buds and fruits large (14-20 × 5-8 mm and 8-12 × 8-12 mm), nonglaucous. Flowers yellow. Calyptra usually $<2 \times$ hypanthium. Fruits cup-shaped to urceolate, broadly flat-topped.

Locally frequent on red desert sandhill country to the north and east of the Nullarbor Plain, extending east to the northwestern Eyre Peninsula (Fig. 11).

Conservation status: not considered to be at risk. 


\section{Eucalyptus dolichocera L.A.S. Johnson E K.D. Hill, sp. nov.}

$\mathrm{Ab}$ E. transcontinentali distinguitur: folia juvenilia non decurrentia, habitus 'malleeformis' (multicaulis); cortex adherens ad 2-3 m; non glauca; calyptra longior attenuata, fructus urceolati, 3-4 loculares.

Type: Western Australia: $34 \mathrm{~km} \mathrm{~S}$ of Wannoo, NW coastal Highway (273' $\left.\mathrm{S}, 114^{\circ} 40^{\prime} \mathrm{E}\right)$, D.F. Blaxell W75/110 \& M.I.H. Brooker, 9 Oct 1975 (holo NSW; iso CANB, PERTH).

[Eucalyptus sp. R, Brooker \& Kleinig (1990)]

Mallee, rarely tree, to $6 \mathrm{~m}$ tall. Bark rough, ribbony to 2-3 $\mathrm{m}$ from base, smooth grey, grey-brown or red-brown above. Juvenile leaves opposite for many nodes, sessile or shortly petiolate, not decurrent, grey-green or slightly glaucous, lanceolate, to $7 \mathrm{~cm}$ long, $1.5 \mathrm{~cm}$ wide. Adult leaves disjunct, lanceolate, acute or acuminate, dull, 7.0-13.0 $\mathrm{cm}$ long, $1.3-2.5 \mathrm{~cm}$ wide; petioles terete, $1.5-1.8 \mathrm{~cm}$ long; lateral veins at $45-50^{\circ}$ to midrib, regular, moderately spaced; secondary reticulum obscure, open, degenerate; intramarginal vein indistinct, 1-2 mm from margin. Umbellasters axillary, 7-flowered; peduncles terete to somewhat angular apically, 10-16 $\mathrm{mm}$ long; pedicels terete, 4-8 mm long. Mature buds ovoid, apically attenuate, 13-20 mm long, 3-5 mm diam.; calyptra narrowly conical, flared at base, 1.5-3 times longer than hypanthium, slightly wider than hypanthium. Stamens all fertile; filaments variably flexed in bud, mostly regularly inflexed with a few outer filaments erect; anthers subglobular, \pm basifixed, versatile; connective gland large; cells divergent, dehiscing by slits. Fruits cup-shaped, urceolate, constricted apically, 3-4-locular, 7-9 mm long, 6-8 mm diam.; calyptra scar flat or slightly depressed, c. $0.5 \mathrm{~mm}$ wide; stemonophore reduced; disc vertically depressed, c. $2 \mathrm{~mm}$ wide; valves deeply enclosed basally, acuminate tips vertically exserted, remnants of persistent style forming tips of valves. Seeds semi-glossy, dark grey-brown, rounded, finely and shallowly reticulate, 1.0-2.0 $\mathrm{mm}$ long; hilum ventral; chaff smaller, angular, brown. (Fig. 12).

E. dolichocera differs from E. transcontinentalis in the non-decurrent juvenile leaves, the non-glaucous habit, the longer attenuate calyptra, the urceolate fruits with 3-4 locules, the mallee habit and the characteristic 'stocking' of rough bark. The leaves are somewhat larger with more oblique and obscure venation.

Locally frequent on laterite or lateritic sand from Wannoo to Dowerin, east to the Wongan Hills district (Fig. 11).

The epithet is from the Greek dolichos, slender, and -ceras, horn or horn-like projection, from the slender, attenuate calyptra.

Conservation status: not considered to be at risk.

Selected specimens (from 47 examined): Western Australia: 9.8 miles [15.7 km] West of Three Springs, Allan 651, 18 July 1971 (PERTH, NSW); 25 m [40 km] N \& W of Yuna, Beard 6868, 19 Oct 1973 (PERTH, NSW); 50 km west of Mullewa on Geraldton Road, Blaxell 1992, 28 May 1983 (NSW, CANB, PERTH); c. $7 \mathrm{~km}$ NW of Watheroo, near E corner of Watheroo National Park, c. $1 \mathrm{~km} \mathrm{~W}$ of Eagle Hill Rd on park boundary track, Briggs 7785 \& Johnson, 1 Oct 1984 (NSW, PERTH); Murchison House Station, $8 \mathrm{~km}$ west of river near homestead, Briggs $8869 \mathcal{E}$ Johnson, 13 Aug 1991 (NSW, CANB, PERTH); 8.2 miles [13.1 km] SW of Three Springs, Brooker 2368, 7 Jan 1970 (PERTH, NSW); Kalguddering rock, Brooker 6761, 2 Jan 1980 (CANB, NSW, PERTH); NW of Wongan Hills, near Pistol Club on Piawaning Rd, Brooker 7591, 26 Aug; 1982 (CANB, NSW); $4.3 \mathrm{~km} \mathrm{~N}$ of Dowerin on Cadoux Rd, Brooker 7609, 14 Sep 1982 (CANB, NSW)4 km $6.7 \mathrm{~km} \mathrm{E}$ of Greenough River bridgeon Geraldton to Mullewa road, Brooker 8138, 27 May 1983 (CANB, NSW); $7.1 \mathrm{~km} \mathrm{~N}$ of Dalwallinu, Brooker 8427, 25 Jan 1984 (CANB, NSW); $1.6 \mathrm{~km}$ E of Bencubbin, Brooker 8492, 16 Mar 1984 (CANB, NSW); $14.4 \mathrm{~km}$ E of highway 1 along State Barrier Fence, NE of Binnu, Brooker 8725, 31 O ct 1984 (CANB, NSW); c. 500 m SE of Mt Michael, Brooker 9200, 12 Mar 1986 (CANB, NSW); 6.9 km from Red Bluff t/o [turnoff] S of Kalbarri, Brooker 9401, 23 July 1986 (CANB, NSW); between Koorda and Cadoux, Brooker 10544, 15 Sep 1990 (CANB, AD, MEL, 


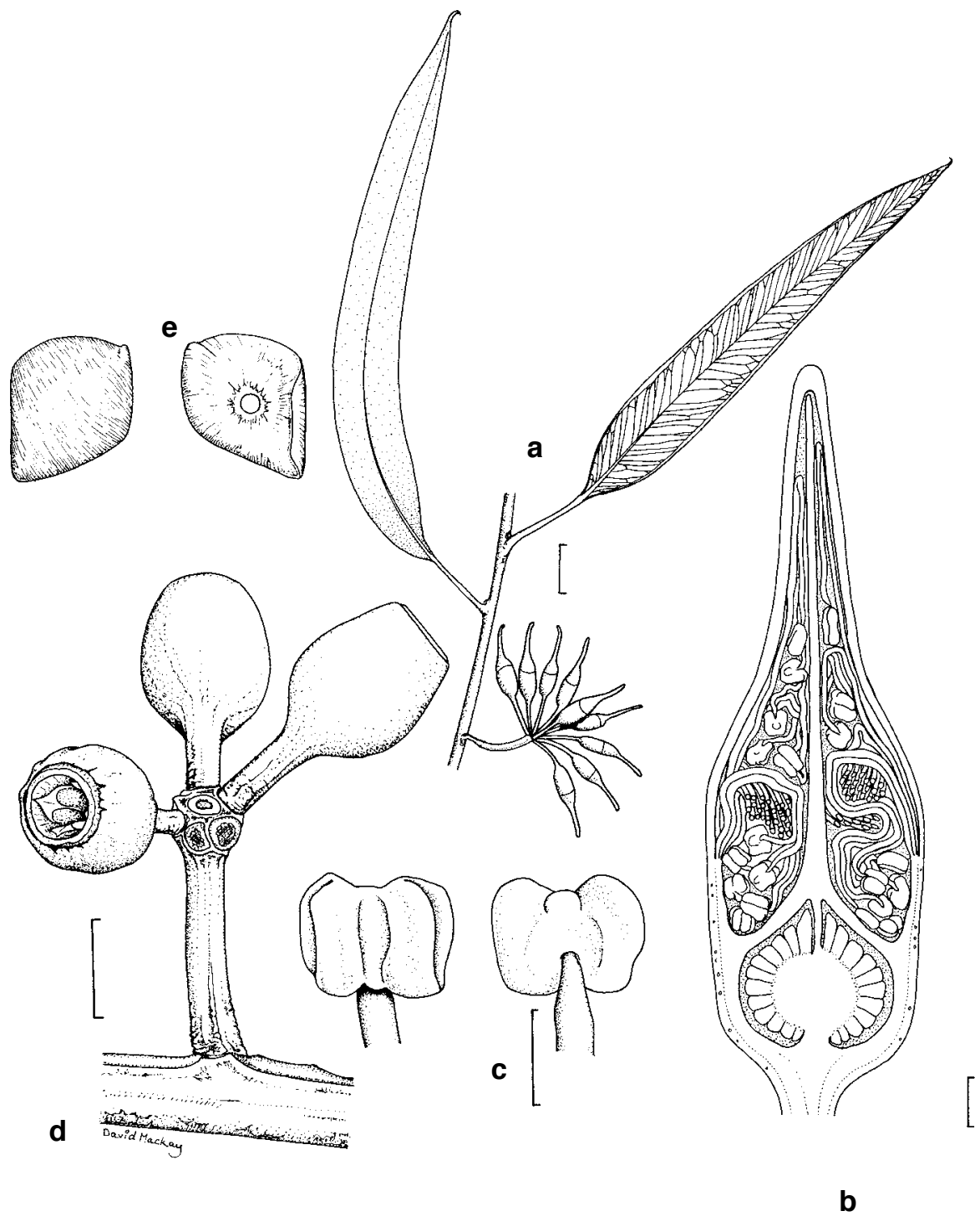

Fig. 12. E. dolichocera. a, adult leaves, inflorescence and buds. $\mathbf{b}$, transverse section of bud. c, anther. $\mathbf{d}$, inflorescence and fruits. e, seed (from Blaxell W75/110). Scale bar: $\mathrm{a}=1 \mathrm{~cm} ; \mathrm{b}, \mathrm{e}=1 \mathrm{~mm}$; $=0.5 \mathrm{~mm} ; \mathrm{d}=5 \mathrm{~mm}$.

NSW, PERTH); 7 miles [11.2 km] N of Watheroo, Chippendale 31, 18 Oct 1966 (CANB, NSW); 1.4 miles [2.2 km] S of Wubin, Chippendale 60, 21 Oct 1966 (CANB, NSW); $25 \mathrm{~km}$ from Piawaning along road to Wongan Hills Town, $1 \mathrm{~km}$ south of road, Crisp 5484, 26 Jan 1979 (CANB, NSW, PERTH); east of York, Diels 5018, (NSW); $16.6 \mathrm{~km}$ west of highway on east-west fence line $57.7 \mathrm{~km}$ north of Murchison River, Hill 2568, Johnson, Brooker E Blaxell, 22 Nov 1986 (NSW, PERTH); Ballidu, opposite grain shed, Hill 2936, 27 Aug 1988 (NSW, CANB, PERTH); Cowcowing, $154 \mathrm{~m}$ [246.4 km] NE of Perth, Koch 1001, Sep 1904 (NSW); Watheroo, Victoria Distr, Morrison 16186, 10 Nov 1906 (K, NSW). 


\section{Subseries Transcontinentalosae}

Subseries defined as follows: juvenile leaves opposite, sessile, decurrent; adult leaves dull; filaments variably flexed in bud, mostly regularly inflexed with a few outer filaments erect, or sometimes all inflexed; style tip inserted into calyptra.

This subseries is restricted to Western Australia, with six species ranging from the north-eastern edges of the Wheat Belt through the Goldfields to the western edges of the Great Victoria Desert.

\section{Eucalyptus moderata L.A.S. Johnson \& K.D. Hill, sp. nov.}

Intra serie Transcontinentali distinguitur: habitus robuste 'malleeformis', cortex versus basin persistens; ramuli alabastraque non glauca; folia juvenilia decurrentia, alabastra relative brevia crassaque ad mediam suburceolata ad cylindrica.

Type: Western Australia: $8.9 \mathrm{~km} \mathrm{~N}$ of Menzies on highway $\left(29^{\circ} 38^{\prime} \mathrm{S}, 121^{\circ} 06^{\prime} \mathrm{E}\right)$, K.D. Hill 537, L.A.S. Johnson, D.F. Blaxell \& M.I.H. Brooker, 4 Nov 1983 (holo NSW; iso CANB, PERTH).

Stout mallee or rarely a small tree to $10 \mathrm{~m}$ tall. Bark persistent on lower trunk, grey, shortly fibrous-flaky or platy, smooth, grey, brown, pink and orange above. Juvenile leaves opposite for many nodes, narrowly elliptical, sessile and strongly decurrent, glaucous, to $6 \mathrm{~cm}$ long, $3 \mathrm{~cm}$ wide. Adult leaves disjunct, lanceolate, acuminate, dull, not glaucous, $5.0-16.0 \mathrm{~cm}$ long, $1.0-3.1 \mathrm{~cm}$ wide; petioles terete, $1.2-2.8 \mathrm{~cm}$ long; lateral veins to $30-45^{\circ}$ to midrib, moderately spaced; secondary reticulum indistinct, slightly degenerate; intramarginal vein distinct, 1-2 $\mathrm{mm}$ from margins. Umbellasters axillary, 7-flowered; peduncles terete, 7-16 $\mathrm{mm}$ long; pedicels terete, 4-9 mm long. Mature buds ovoid, rostrate, 12-15 mm long, 5-6 mm diam.; calyptra hemispherical, strongly rostrate for more than half length, c. 1.5 times longer than hypanthium. Stamens all fertile; anthers subglobular, \pm basifixed, versatile; connective gland large; cells dehiscing by slits. Fruits globular, not glaucous, 3-4-locular, 7-10 mm long, 6-9 mm diam.; calyptra scar flat, $0.5-1.0 \mathrm{~mm}$ wide; disc depressed at $60-80^{\circ}, 1-2 \mathrm{~mm}$ wide; valves deeply enclosed basally, acuminate tips vertically exserted, remnants of persistent style forming tips of valves. Seeds semiglossy, dark grey-brown, rounded, finely and shallowly reticulate, $1.0-1.5 \mathrm{~mm}$ long; chaff dull, brown, angular (Fig. 13).

Distinguished by the combination: stout mallee; bark persistent on lower trunk; twigs and buds not glaucous; juvenile leaves decurrent; buds relatively short and thick; buds and fruits small to medium, suburceolate to cylindrical.

Locally frequent on red desert sandy loam in the Northern Goldfields, known from near Menzies, near Comet Vale, and near Musson's Soak (Fig. 14). Associated species include E. oldfieldii, E. ceratocorys, E. ebbanoensis, E. concinna, Acacia aneura and Triodia. Two specimens collected to the east and south-east of this range (below) may belong here, but require further assessment.

The epithet is from the Latin moderatus, moderate, from the medium stature in habit and sizes of leaves, buds and fruits, as compared with its closest relatives.

Conservation status: not considered to be at risk.

Selected specimens (from 13 examined): Western Australia: near Sand Queen Mine, 61.6 miles [98.6 km] N of Kalgoorlie, Baker 88, 17 Nov 1970 (CANB, NSW); 28 km S of Menzies, Beadle 78, 27 Oct 1972 (NSW); $11.2 \mathrm{~km}$ east of Die Hardy Range road on Diemals to Menzies road, Brooker 8697, 16 Oct 1984 (CANB, NSW); $14.4 \mathrm{~km}$ west of Callion on Mussons Soak road, Hill 2656 \& Johnson, 28 Nov 1986 (NSW, PERTH); 6 miles [9.6 km] N of Comet Vale, Johnson W 150, W 151, 17 Dec 1960 (NSW); 1-2 miles [1.6-3.2 km] S of Comet Vale, Johnson W 155, 17 Dec 1960 (NSW); Comet Vale, Maiden, Sep 1909 (NSW). 


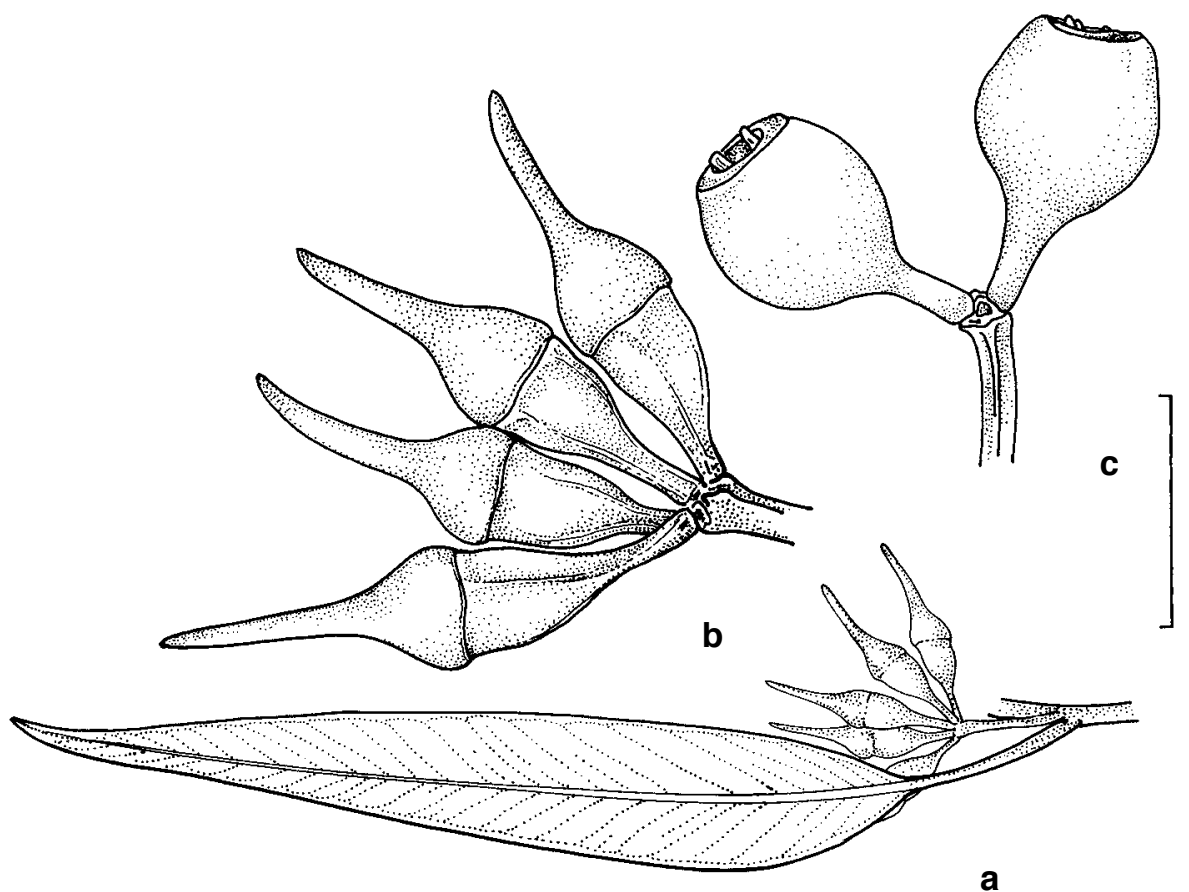

Fig. 13. E. moderata. a, adult leaves, inflorescence and buds. b, inflorescence and buds. c, inflorescence and fruits. (from Brooker 9605). Scale bar: $a=3 \mathrm{~cm} ; \mathrm{b}, \mathrm{c}=1 \mathrm{~cm}$.

Eastern outliers: $85 \mathrm{~km} \mathrm{~W}$ of Balladonia roadhouse on highway, Hill 2210 E Johnson, 4 Nov 1986 (NSW, CANB, MEL, PERTH); $75.6 \mathrm{~km} \mathrm{~S}$ of turnoff near Zanthus on

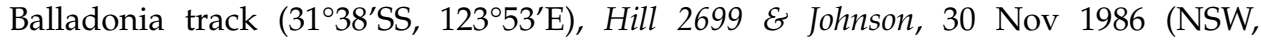
PERTH).

23. Eucalyptus transcontinentalis Maiden, J. E Proc. Roy. Soc. New South Wales 53: 58 (1919).

Type: Western Australia: Kalgoorlie, J.H. Maiden s.n., Sep 1909 (holo NSW). Figs 8 a-d, plate 66, C.R.

=E. uncinata Turcz. var. rostrata Benth., Fl. Austral. 3: 216 (1867), in part.

Type: cited as 'Phillips Range, Maxwell; Murchison River, Oldfield, also Drummond, 5th Coll. n. 186.' The material cited is referable to two taxa, the Drummond collection representing E. transcontinentalis. Bentham (1867: 249) also refers Drummond's 5th collection no. 186 to E. decurva F. Muell. without explaining the two different citations of apparently the same material. Material of Drummond's collection at MB, CGE, $\mathrm{K}$ and MEL has been determined as E. transcontinentalis by Maiden (C.R. 2: 173) and ourselves.

[E. decurva auct. non F. Muell.: Benth., Fl. Austral. 3: 249 (1867). Bentham also included authentic material of E. decurva in his circumscription.]

=E. oleosa F. Muell. var. glauca Maiden, J. Western Australian Nat. Hist. Soc. 3: 171 (1911). 
Type: Western Australia: 70 miles north of Kurrawang, W.A., J.H. Maiden, Sep 1909 (lecto NSW, here designated). Maiden did not cite a specimen, but stated in the protologue: 'Seventy miles north of Kalgoorlie I took notes on the spot of a tree as follows: A Medium-size tree, say one foot in diameter, a White Gum with blotched bark and more or less short flaky ribbons on the trunk, with a little roughness at the butt.' E. socialis is listed as a synonym. He later stated: 'Specimens collected by me about 70 miles north of Kurrawang and also at Kalgoorlie, September 1909, may be taken as the type' (C.R. 2: 172). He subsequently selected the specimens from Kalgoorlie as the type for E. transcontinentalis, not mentioning E. socialis in synonymy.

Tree to $12 \mathrm{~m}$ tall. Bark persistent on lower 2-3 m of trunk, hard, scaly-fibrous, dark grey; smooth, white above, or wholly smooth, white, sometimes with pale grey or pink patches. All parts \pm glaucous. Juvenile leaves opposite, sessile, elliptical, obtuse or rounded, to $7 \mathrm{~cm}$ long, $3 \mathrm{~cm}$ wide; leaf margins decurrent. Adult leaves disjunct, narrow-lanceolate to lanceolate, acuminate, dull, 5-15 cm long, $0.6-2.5 \mathrm{~cm}$ wide; petioles terete, $0.7-2.5 \mathrm{~cm}$ long; lateral veins to $30-45^{\circ}$ to midrib, moderately spaced; secondary reticulum indistinct, slightly degenerate; intramarginal vein distinct, 1-2 mm from margins. Umbellasters axillary, 7-flowered; peduncles terete, often decurved, 5-15 mm long; pedicels terete, 2-8 mm long. Mature buds ovoid, rostrate, 14-20 mm long, 5-7 mm diam.; calyptra basally hemispherical, strongly rostrate for more than half length, 2-3 times longer than hypanthium. Stamens all fertile; anthers subglobular, \pm basifixed, versatile; connective gland large; cells dehiscing by slits. Fruits cup-shaped to hemispherical, 3-4-locular, 5-9 mm long, 5-8 mm diam.; calyptra scar and stemonophore flat, c. $0.5 \mathrm{~mm}$ wide; disc flat slightly to strongly depressed, 1.0-1.5 mm wide; valves deeply enclosed basally, acuminate tips vertically exserted, remnants of persistent style forming tips of valves. Seeds semiglossy, grey-brown, rounded, finely and shallowly reticulate, 1.0-1.5 mm long; chaff dull, brown, angular.

Two geographic subspecies are recognised.

Bark wholly smooth

23A. subsp. transcontinentalis

Bark persistent on lower trunk

23B. subsp. semivestita

\section{A. Eucalyptus transcontinentalis subsp. transcontinentalis}

Bark wholly smooth, white, sometimes with pale grey or pink patches. Adult leaves 5-15 cm long, 0.8-2.5 cm wide; petioles terete, $1.5-2.5 \mathrm{~cm}$ long. Peduncles 5-12 mm long; pedicels $2-5 \mathrm{~mm}$ long. Mature buds $14-18 \mathrm{~mm}$ long, 5-7 mm diam. Fruits 5-8 mm long, 5-8 mm diam.

Locally abundant in open woodland on flat sites on calcareous loams in the Goldfields region, from Goongarrie to the Fraser Range (Fig. 14). A wide range of asociated eucalypt species has been recorded, commonly including E. salmonophloia, E. celastroides and E. urna, with an open shrub understorey of Melaleuca spp.

Conservation status: not considered to be at risk.

Selected specimens (from 42 examined): Western Australia: 20.4 miles [32.6 km] S of Kalgoorlie-Boulder Shire boundary, along Great Eastern Highway, then 12.6 miles [20.2 km] E along Mt Martin Road, Baker 9, 9 Nov 1970 (CANB, NSW); (R) side, off Great Eastern Highway, 34.5 miles [55.2 km] N of Norseman, Baker 39, 10 Nov 1970 (CANB, NSW); $30 \mathrm{~m}$ [48 km] NE of Mt Ney, Beard 6374, 17 Sep 1970 (KPBG, NSW); 32 km N of Kambalda, Brooker 6400, 21 Aug 1979 (CANB, NSW); $25.6 \mathrm{~km}$ E of Nepean Mine towards Spargoville, Brooker 9081, 12 Nov 1985 (CANB, NSW); W of North Ironcap, E of Hyden, Brooker 10052, 24 Aug 1988 (CANB, NSW); 27.5 miles [44 km] N of Kalgoorlie, Chippendale 121, 9 Mar 1967 (CANB, NSW); Kalgoorlie, Cleland 7, 3 Sep 1926 (NSW); Hampton Hill Station, ca 36 km ESE of Kalgoorlie, Coveny 8423 \& Habersley, 14 Sep 1976 (NSW, CANB, K, L, PERTH); 26 km SSW of Coolgardie along road to Gnarlbine Rock, Crisp 1979, 31 Jan 1979 (CANB, NSW, PERTH); Coolgardie pr Kanowna, Diels 1703, 28 Nov 1900 (B, 
NSW); 10.5 km S of Coolgardie on Gnarlbine Soak Road (near grid 2), Forbes 1474, 6 Oct 1983 (MEL, CANB, NSW, PERTH); Coolgardie, Helms 99, 1899 (NSW); 25 km S of Goongarrie rly station on hwy, Hill 547 \& Johnson, 4 Nov 1983 (NSW, CANB, PERTH); $43 \mathrm{~km}$ E of Norseman on hwy 1, Hill 686 \& Blaxell, 14 Nov 1983 (NSW, CANB, PERTH); 42.5 km from Highway on Peak Charles road, Hill 2330 Johnson \& Blaxell, 8 Nov 1986 (NSW, PERTH); $102.5 \mathrm{~km} \mathrm{~W}$ of Balladonia roadhouse on hwy, Hill 2829, 24 Aug 1988 (NSW); $10.7 \mathrm{~km} \mathrm{~W}$ of Coolgardie to Norseman rd on Hyden track, Hill 2840, 25 Aug 1988 (NSW, CANB, PERTH); $46.0 \mathrm{~km} \mathrm{~N}$ of Coolgardie to Hyden rd on Varley to Southern Cross rd, Hill 2895, 26 Aug 1988 (NSW, CANB, PERTH); 70 miles [112 km] N of Kurrawangs, Maiden, Sep 1909 (NSW); ca. 35 km north of Widgiemooltha along Eyre Highway between Coolgardie and Widgiemooltha, Orchard 1251, 30 Sep 1968 (AD, NSW); 44 miles [70.4 km] N of Norseman, Phillips, 11 Sep 1962 (CANB, NSW); between Kalgoorlie to Coolgardie on highway, Phillips, 15 Sep 1962 (CANB, NSW); 6.3 miles [10.1 km] N of Kalgoorlie, Eremean Province, Speck 899, 6 July 1958 (CANB, NSW); Bulla Bulling, Stoward 87, Mar 1917 (NSW); Coolgardie, Webster, 1898 (NSW).

23B. Eucalyptus transcontinentalis subsp. semivestita L.A.S. Johnson E K.D. Hill, subsp. nov.

Cortex ad parte basali (ad 2-3 m) densus et squamifibrosus, supra laevis, albusque.

Type: Western Australia: Noongar (3120'S, 118 58'E), R. Coveny 8373 E B. Habersley, 12 Nov 1976 (holo NSW; iso CANB, PERTH).

Bark persistent on lower 2-3 m of trunk, hard, scaly-fibrous, dark grey; smooth, white above. Adult leaves 5-13 cm long, $0.6-2.4 \mathrm{~cm}$ wide; petioles terete, $0.7-2.2 \mathrm{~cm}$ long. Peduncles 5-15 mm long; pedicels 3-8 mm long. Mature buds $15-20 \mathrm{~mm}$ long, 5-6 mm diam. Fruits 5-9 mm long, 5-7 mm diam (Fig. 15).

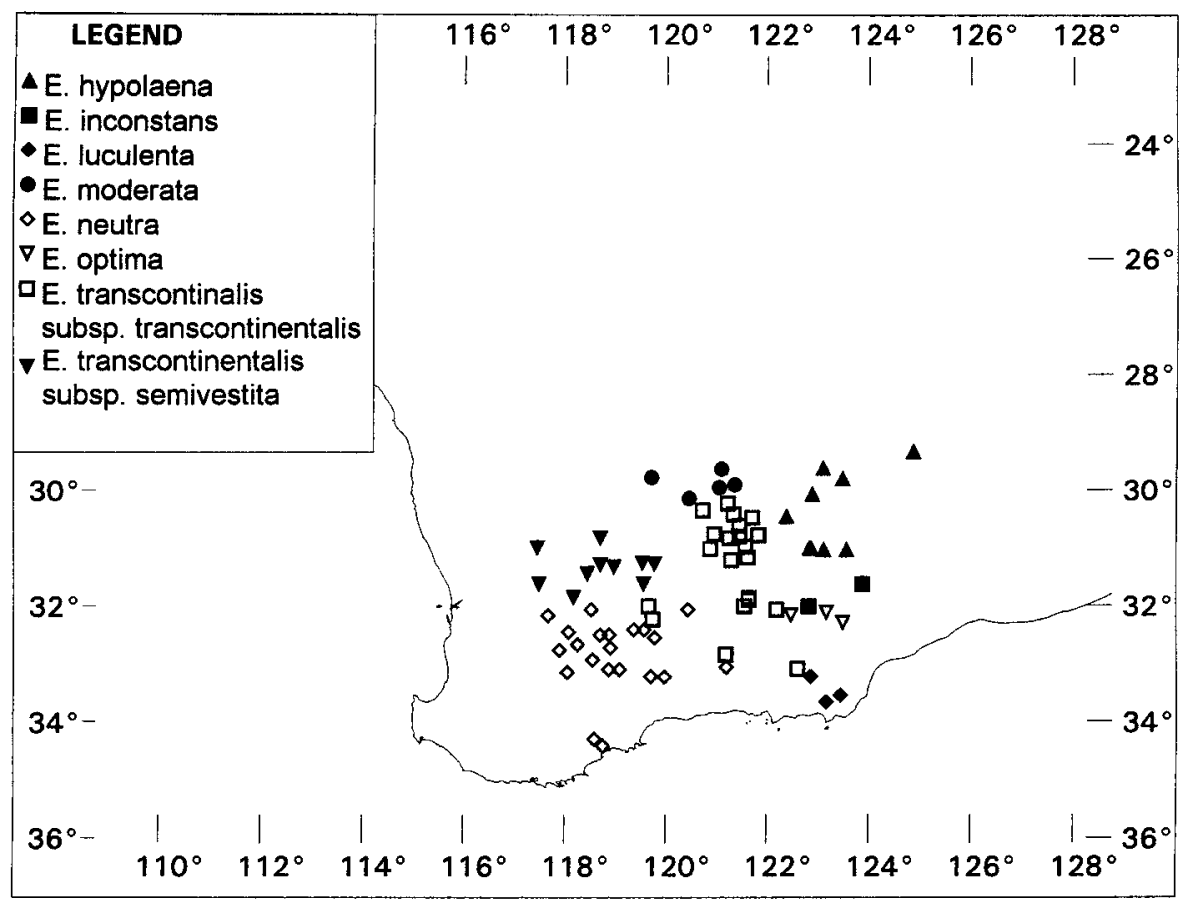

Fig. 14. Distribution of E. hypolaena, E. luculenta, E. moderata, E. neutra, E. optima, E. transcontinentalis subsp. transcontinentalis and E. transcontinentalis subsp. semivestita. 


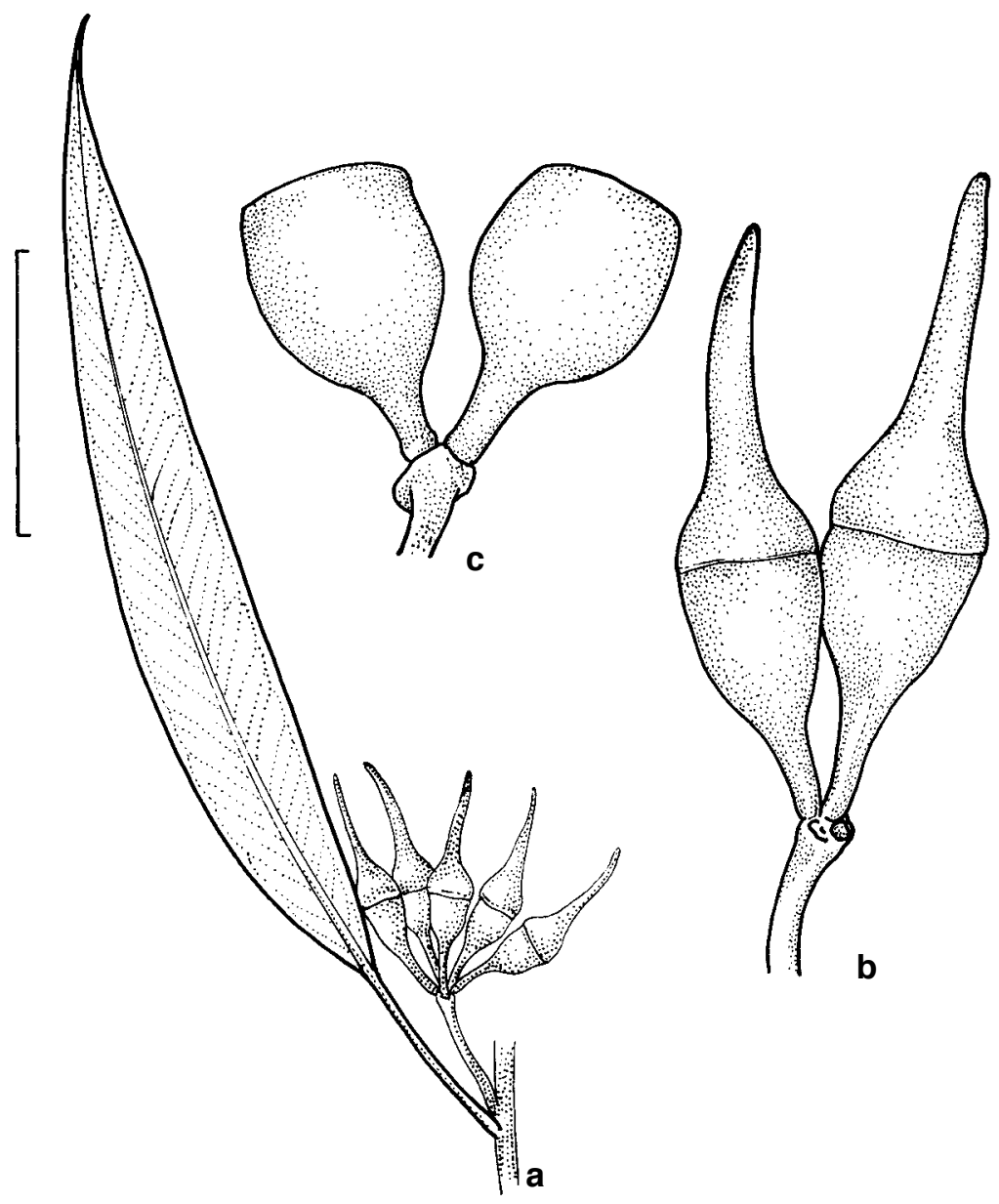

Fig. 15. E. transcontinentalis subsp. semivestita. $\mathbf{a}$, adult leaves, inflorescence and buds. $\mathbf{b}$, inflorescence and buds. $\mathrm{c}$, inflorescence and fruits. (from Hill 1767). Scale bar: $\mathrm{a}=3 \mathrm{~cm} ; \mathrm{b}, \mathrm{c}=1 \mathrm{~cm}$.

Locally frequent in the eastern wheatbelt, from Cowcowing to Kellandi (Fig. 14). Usually on flat sites, on red somewhat sandy soils, soils tending to be sandier in the west of the range and more loamy in the east. Associated species include E. salmonophloia and E. salubris, with Acacia and Melaleuca spp. dominating the understorey.

The epithet is from the Latin vestitus, clothed, with the latin prefix semi-, half, in reference to the persistent bark over the lower half of the trunk

Conservation status: not considered to be at risk.

Selected specimens (from 12 examined): Western Australia: $7 \mathrm{~km} \mathrm{~N}$ of Merredin on Nungarin Rd, Brooker 7619, 15 Sep 1982 (CANB, NSW); Chiddarcooping Nature Reserve, N end, Brooker 7981, 17 Feb 1983 (CANB, NSW); 10 km NE of Menzies, Brooker 9605, 6 May 1987 (CANB, NSW); $30 \mathrm{~km}$ NW of Coolgardie on Jaurdi road, Brooker 9698, 27 June 1987 (CANB, NSW); Noongar, Chippendale 95, 6 Mar 1967 (CANB, NSW); 7.4 miles [11.8 km] E of Ghooli, Chippendale 102, 7 Mar 1967 (CANB, NSW); Tammin, Diels 2854, (B, NSW); Tammin, Diels D \& Pritzel, May 1901 (NSW, NSW); Westonia, Gardner 1767, 4 Oct 1922 (PERTH, NSW); $93.0 \mathrm{~km} \mathrm{~N}$ of Coolgardie to Hyden rd 
on Varley to Southern Cross rd, Hill 2907, 26 Aug 1988 (NSW, CANB, PERTH); near Kellandi (ca $28 \mathrm{~m}$ [44.8 km] E of Southern Cross), Johnson W 137, 16 Dec 1960 (NSW); Cowcowing, Koch 1001 p.p, Sep 1904 (NSW); The Bruce Rock, Merredin district, Stoward 14, Sep 1916 (NSW).

\section{Eucalyptus optima L.A.S. Johnson \& K.D. Hill, sp. nov.}

Intra subserie Transcontinentali distinguitur: folia magna, alabastra magna calyptra plus rostrata, fructus magni pedicellis longioribus. Cortex omnino laevis. Ramuli et alabastra glauca.

Type: Western Australia: $20.2 \mathrm{~km}$ W of Balladonia roadhouse on Highway 1 (32 $15^{\circ} \mathrm{S}$, $\left.123^{\circ} 26^{\prime} \mathrm{E}\right)$, K. Hill $212 \mathcal{E}$ L. Johnson, 19 Oct 1983 (holo NSW; iso CANB, PERTH).

[Eucalyptus sp. P subsp. P, Brooker \& Kleinig (1990)]

Tree to $20 \mathrm{~m}$ tall. Bark smooth, white, sometimes with pale yellow or orange patches. All parts \pm glaucous. Juvenile leaves opposite, sessile, lanceolate, acuminate, to 18 $\mathrm{cm}$ long, $5 \mathrm{~cm}$ wide; leaf margins strongly decurrent; juvenile stems 4 -winged. Adult leaves disjunct, lanceolate, acute or acuminate, dull, $8.0-18.0 \mathrm{~cm}$ long, $1.2-4.2 \mathrm{~cm}$ wide; petioles terete, $2.0-4.0 \mathrm{~cm}$ long; lateral veins to $30-45^{\circ}$ to midrib, moderately spaced; secondary reticulum indistinct, slightly degenerate; intramarginal vein distinct, 1-2 mm from margins. Umbellasters axillary, 7-flowered; peduncles terete, 13-20 mm long; pedicels terete, 7-12 mm long. Mature buds ovoid, rostrate, $17-20 \mathrm{~mm}$ long, 6-8 $\mathrm{mm}$ diam.; calyptra basally hemispherical, strongly rostrate for more than half length, c. 2 times longer than hypanthium. Stamens all fertile; anthers subglobular, \pm basifixed, versatile; connective gland large; cells dehiscing by slits. Fruits cup-shaped to hemispherical, 4-5-locular, 8-10 mm long, 9-12 mm diam.; calyptra scar flat, 0.5-1.0 $\mathrm{mm}$ wide; disc flat or slightly depressed, $1.0-1.5 \mathrm{~mm}$ wide; valves deeply enclosed basally, acuminate tips vertically exserted, remnants of persistent style forming tips of valves. Seeds semiglossy, dark grey-brown, rounded, finely and shallowly reticulate, 1.0-1.5 mm long; chaff dull, brown, angular. (Fig. 16).

Distinguished by the large leaves, large buds with a more markedly rostrate calyptra and large fruits with longer pedicels. Bark wholly smooth. Twigs and buds glaucous.

The dominant species in woodlands on calcareous sandy loams, with a wide range of associated species. E. optima occurs in the region between Balladonia and the Fraser Range (Fig. 14).

The specific epithet is from the Latin, optimus, best, in reference to this species being the largest in stature and sizes of buds and fruits in the series.

Conservation status: not considered to be at risk.

Selected specimens (from 12 examined): Western Australia: 96 miles [153.6 km] by road east of Norseman towards Balladonia, Brooker 3650, 26 Apr 1972 (CANB, NSW); 24 miles [3804 km] west of Balladonia towards Norseman, Brooker 3651, 26 Apr 1972 (CANB, NSW); ca. 15-20 km NW of Balladonia on Norseman road, Brooker 6439, 22 Aug 1979 (CANB, NSW); $14.3 \mathrm{~km}$ NW of Balladonia, Brooker 8479, 12 Mar 1984 (CANB, NSW); 1/2 km N of Hwy 1 on track of Newmans Rock, $48.8 \mathrm{~km} \mathrm{~W}$ of Balladonia Roadhouse, Hill 227 \& Johnson, 19 Oct 1983 (NSW); $16.9 \mathrm{~km} \mathrm{~W}$ of Balladonia roadhouse on highway, Hill 2186, 2187 \& Johnson, 4 Nov 1986 (NSW, CANB, MEL, PERTH); $109 \mathrm{mls}$ [174.4 km] E Norseman, Moore, 14 Dec 1974 (CANB, NSW); 53 miles [84.8 km] E of Norseman, on Eyre Highway, Phillips, 10 Sep 1962 (CANB, NSW); c. 30 miles [48 km] W of Balladonia Homestead, Phillips, 10 Sep 1962 (CANB, NSW).

\section{Eucalyptus hypolaena L.A.S. Johnson E K.D. Hill, sp. nov.}

Intra subserie Transcontinentali distinguitur: cortex basi trunci (ad 2-3 m) persistens, induratus, squamoso-fibrosusque, supra laevis albusque; alabastra et fructis magnique. 


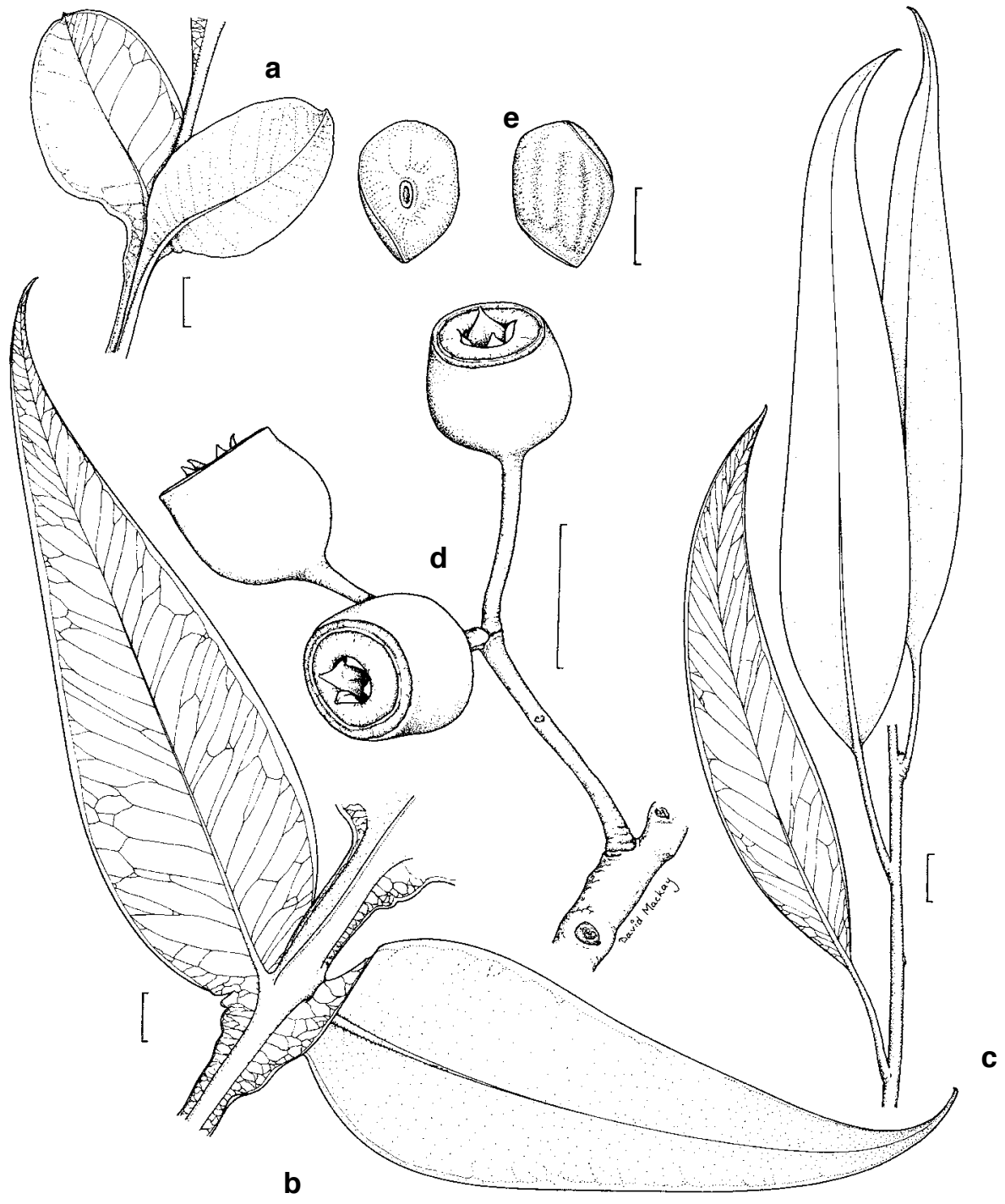

Fig. 16. E. optima. a, early juvenile leaves. $\mathbf{b}$, later juvenile leaves. $\mathbf{c}$, adult leaves. $\mathbf{d}$, inflorescence and fruits. e, seed (a, c, d, e from Hill 212, b from Brooker 3651). Scale bar: a, b, c, d = $1 \mathrm{~cm}$; e = $1 \mathrm{~mm}$.

Type: Western Australia: $56.8 \mathrm{~km}$ E of Karonie along transcontinental railway, $2.6 \mathrm{~km}$ $\mathrm{S}$ of track $\left(31^{\circ} 2^{\prime} \mathrm{S}, 123^{\circ} 7^{\prime} \mathrm{E}\right)$, K.D. Hill 562, L.A.S. Johnson, D.F. Blaxell, M.I.H. Brooker, S. Hopper, 5 Nov 1983 (holo NSW; iso CANB, K, PERTH).

[Eucalyptus sp. P subsp. 'blackbutt', Brooker \& Kleinig (1990)]

Tree or mallee to $15 \mathrm{~m}$ tall. Bark persistent on lower 2-3 m of trunk, hard, scaly-fibrous, dark grey; smooth, white above. Juvenile leaves opposite, sessile, broad lanceolate to ovate, acute, to $12 \mathrm{~cm}$ long, $5 \mathrm{~cm}$ wide; leaf margins decurrent, juvenile stems 4 -winged. 
Adult leaves disjunt, lanceolate, acute or acuminate, dull, 8.0-15.0 cm long, 1.5-3.0 $\mathrm{cm}$ wide; petioles terete, $1.5-3.5 \mathrm{~cm}$ long; lateral veins at $30-45^{\circ}$ to midrib, regular, moderately spaced; secondary reticulum open, somewhat degenerate; intramarginal vein distinct, 1.0-2.0 mm from margin. Umbellasters axillary, 7-flowered; peduncles terete, 9-16 mm long; pedicels terete, 6-10 mm long. Mature buds ovoid, rostrate, 14$22 \mathrm{~mm}$ long, 6-7 mm diam.; calyptra hemispherical, strongly rostrate for $1 / 2$ to $3 / 4$ length, 1.5-2.5 times longer than hypanthium, slightly wider than hypanthium. Stamens all fertile; anthers subglobular, \pm basifixed, versatile; connective gland large; cells divergent, dehiscing by slits. Fruits globular, apically constricted, 4-5 locular, 8-10 mm long, 9-10 mm diam.; calyptra scar flat or slightly raised, $0.5 \mathrm{~mm}$ wide; stemonophore flat or slightly raised, c. $0.5 \mathrm{~mm}$ wide; disc almost verticaly depressed, 1-2 $\mathrm{mm}$ wide; valves deeply enclosed basally, acuminate tips vertically exserted, remnants of persistent style forming tips of valves. Seeds semi glossy, brown, rounded, finely and shallowly reticulate, 1.0-1.5 mm long; chaff similar, smaller, angular. (Fig. 17).

E. hypolaena is distinguished by the large glaucous buds and fruits and the distinct 'stocking' of hard, rough bark.

This species occurs east of Kalgoorlie, in the Karonie-Zanthus district, and north and east of there into the Great Victoria Desert (Fig. 14).

Locally dominant on red sandy loam on flats, in mallee-woodland with E. yilgarnensis, E. celastroides and a number of less common species.

The specific epithet is from the Greek hypo, under, and (ch)laena, a cloak, referring to the persistent bark on the lower trunk.

Conservation status: not considered to be at risk.

Selected specimens (from 14 examined): Western Australia: 22.8 miles [36.5 km] east of Karonie, Brooker 2463, 13 Feb 1970 (PERTH, NSW); 29 km NNW of airstrip, W of Plumridge Lakes, Great Victoria Desert, Brooker 8570, 13 May 1984 (CANB, NSW); 19 km from Pinjin towards Kirgella, Brooker 8592, 15 May 1984 (CANB, NSW); $11 \mathrm{~km} \mathrm{~W}$ of approach track from S, south of Lake Minigwal, Brooker 8601, 16 May 1984 (CANB, NSW); 35.3 km E of Karonie, Brooker 9617, 7 May 1987 (CANB, NSW); 18 km from Kurnalpi to Pinjin, Brooker 9665, 24 June 1987 (CANB, NSW); 37 km NW of Officer Basin, Brooker 9682, 25 June 1987 (CANB, NSW); Zanthus, Cain s.n., 1945 (NSW); Zanthus, Cleland 1, 4, 21 Aug 1926 (NSW); $16.1 \mathrm{~km}$ E of Pinjin road on PNC road, Hill 2664 $\mathcal{E}$ Johnson, 29 Nov 1986 (NSW, PERTH).

26. Eucalyptus neutra D. Nicolle, Austral. Syst. Bot. 12 [in press]

Type: Western Australia: 9.6 km E of Newdegate, M.I.H. Brooker 9649, 19 May 1987 (holo PERTH, iso AD, CANB, NSW).

[Eucalyptus sp. Q, Brooker \& Kleinig (1990)]

Mallee to $6 \mathrm{~m}$ tall. Bark smooth, grey-white; rarely rough at base. Plant \pm glaucous. Adult leaves disjunct, lanceolate to broad-lanceolate, acute or acuminate, dull, 5-9 cm long, $0.9-2.0 \mathrm{~cm}$ wide; petioles terete or slightly flattened, $0.9-2.0 \mathrm{~cm}$ long; lateral veins at c. $45^{\circ}$ to midrib, regular, moderately spaced; secondary reticulum open, somewhat degenerate; intramarginal vein distinct, $0.5-1.5 \mathrm{~mm}$ from margin. Umbellasters axillary, 7-flowered; peduncles terete, 4-10 mm long; pedicels terete, 1-5 mm long. Mature buds elongate ovoid, apically tapered and \pm rostrate, $10-15 \mathrm{~mm}$ long, 4-5 mm diam.; calyptra narrowly conical, flared at base, 1.5-2 times longer than hypanthium, slightly wider than hypanthium. Stamens all fertile; anthers subglobular, \pm basifixed, versatile; connective gland large; cells divergent, dehiscing by short slits. Fruits cupshaped to urceolate, apically constricted, 4-5-locular, 6-9 mm long, 5-8 mm diam.; calyptra scar \pm raised, c. $0.5 \mathrm{~mm}$ wide; stemonophore sharply depressed, less than 0.5 $\mathrm{mm}$ wide; disc \pm vertically depressed, $1-1.5 \mathrm{~mm}$ wide; valves deeply enclosed basally, 


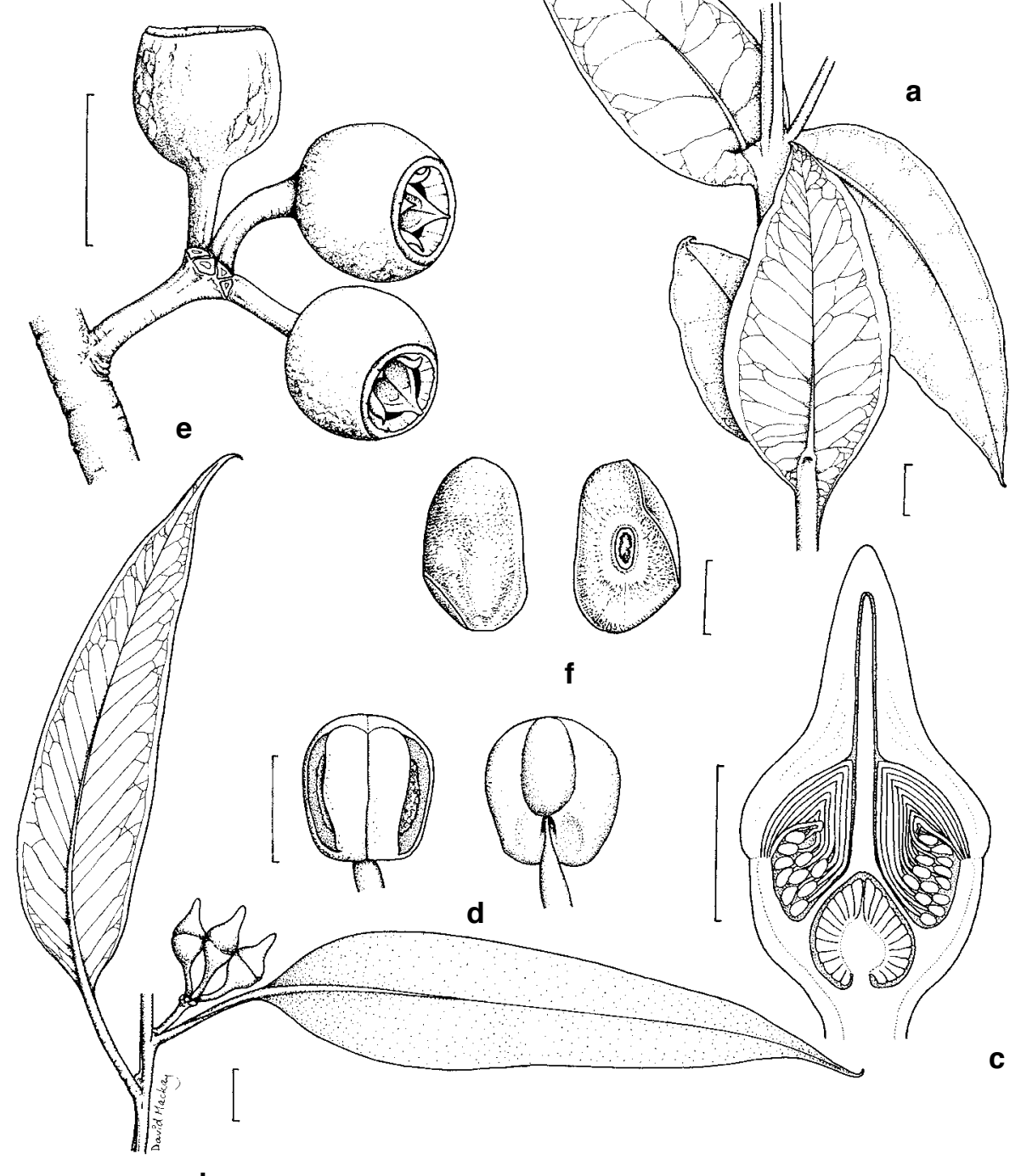

b

Fig. 17. E. hypolaena. a, juvenile leaves. $\mathbf{b}$, adult leaves, inflorescence and buds. $\mathbf{c}$, transverse section of bud. d, anther. e, inflorescence and fruits. f, seed (a, e, f from Hill 562, b, c, d from Cain s.n. 1945). Scale bar: $a, b, e=1 \mathrm{~cm} ; c=5 \mathrm{~mm} ; d=0.5 \mathrm{~mm} ; \mathrm{f}=1 \mathrm{~mm}$.

acuminate tips vertically exserted, remnants of persistent style forming tips of valves. Seeds semi glossy, dark grey brown, rounded, finely and shallowly reticulate, $1.0-1.5 \mathrm{~mm}$ long; hilum ventral; chaff similar, smaller glossy pale brown (Fig. 18).

E. neutra differs from E. transcontinentalis in the consistent mallee habit and the shorter pedicels. It is distinguished within the Transcontinentalosae by the following characters: mallee habit; bark smooth; buds and fruits consistently glaucous; fruits usually globular. 
Scattered in occurrence and nowhere very common, this species is a member of the mallee-heath communities on lateritic sandplain or rocky breakaways, sometimes extending into E. salmonophloia woodland communities. From Kondinin to Mt Day, south to the Pallinup River (Fig. 14).

Conservation status: not considered to be at risk.

Selected specimens (from 32 examined): Western Australia: $65 \mathrm{~km} \mathrm{~S}$. of Jerramungup on Albany rd $\left(34^{\circ} 30^{\prime}\right.$ S, $\left.118^{\circ} 10^{\prime} \mathrm{E}\right)$, D.F. Blaxell 2015, L.A.S. Johnson \& M.I.H. Brooker, 2 June 1983 (NSW, AD, CANB, K, MEL, PERTH), $7.4 \mathrm{~km}$ E of Hyden, Blaxell W 75/21 \& Brooker, 3 Oct 1975 (NSW, PERTH); $2.7 \mathrm{~km} \mathrm{~S}$ of Hyden to Norseman road on road $6 \mathrm{~km} \mathrm{~W}$ of crossroads, Brooker 6315, 6316, $11 \mathrm{Aug}$ 1979 (CANB, NSW, PERTH); $3.1 \mathrm{~km}$ N of Ravensthorpe to Lake King road on Hatters Hill road, Brooker 8679, 8 Sep 1984 (CANB, NSW); between Pallinup River and Bremer Bay t/o [turnoff] on highway 1, Brooker 8944, 12 Apr 1985 (CANB, NSW); $5.7 \mathrm{~km}$ from end of made road up Fields road to north, Brooker 9529, 8 Nov 1986 (CANB, NSW); $9.6 \mathrm{~km}$ E of Newdegate Brooker 9650, 19 May 1987 (CANB, NSW); $11 \mathrm{~km} \mathrm{~S}$ of Kondinin along road to Kulin, Crisp 5525, 28 Jan 1979 (CANB, NSW, PERTH); 27 km E of Pingaring along road to Varley, Crisp 5544, 28 Jan 1979 (CANB, NSW, PERTH); $15.8 \mathrm{~km} \mathrm{~N}$ of Hyden to Norseman track on Mt Day turnoff, turning off $123 \mathrm{~km} \mathrm{~W}$ of Norseman to Coolgardie rd, Hill 628, 629, Johnson, Blaxell, Brooker \&, 7 Nov 1983 (NSW, CANB, PERTH); $67.5 \mathrm{~km}$ E of Hyden on track to Norseman, Hill 640, Johnson, Blaxell, Brooker \& Hopper, 7 Nov 1983 (NSW); $48.5 \mathrm{~km} \mathrm{~S}$ of Brookton to Corrigin rd on Dudinin rd, Hill 2993, 31 Aug 1988 (NSW); $18.7 \mathrm{~km} \mathrm{~N}$ of

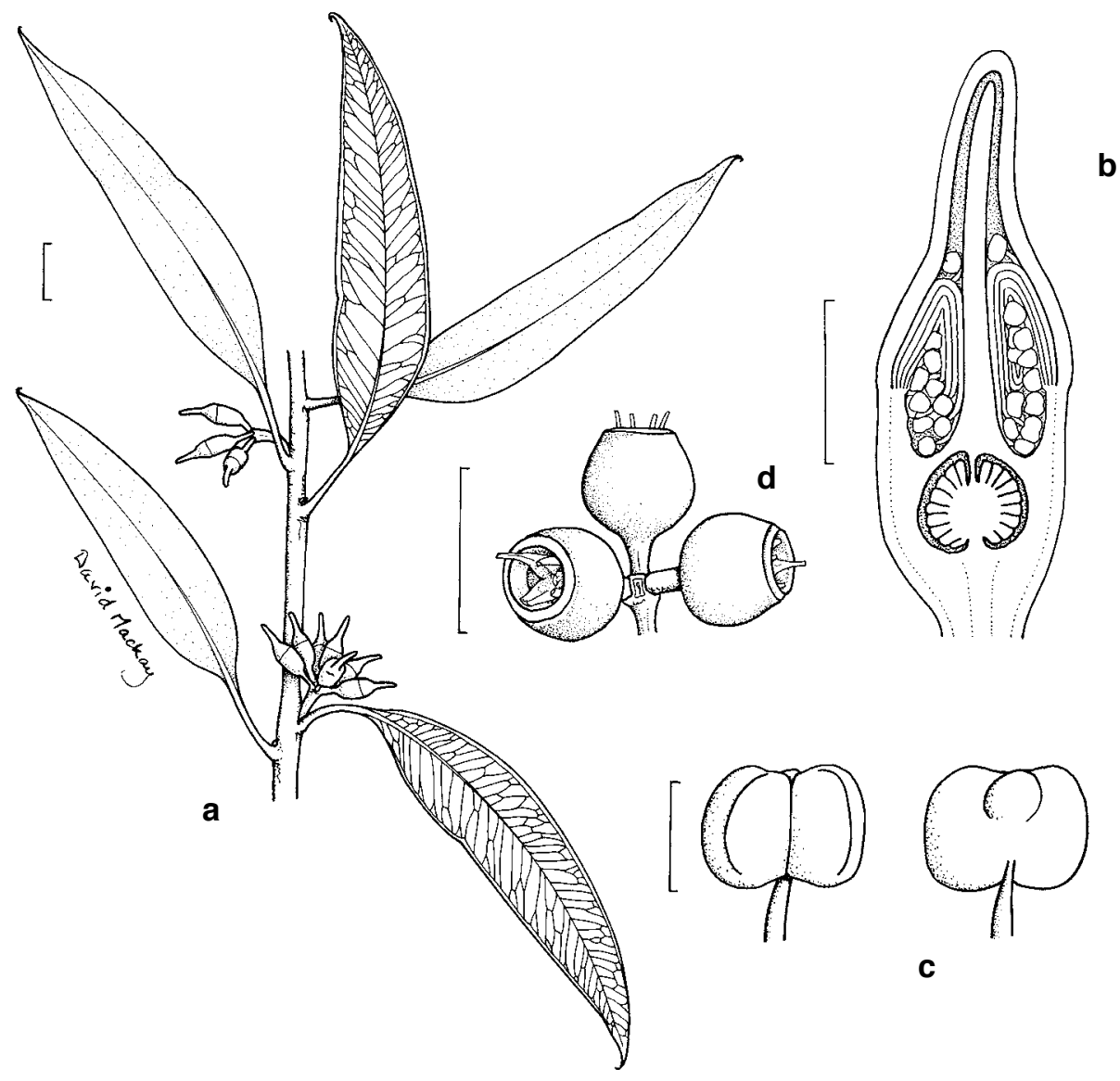

Fig. 18 E. neutra a, adult leaves, inflorescences and buds. b, transverse section of bud. c, anther. d. infloresence and fruits (from Blaxell 2015). Scale bar: $a, d=1 \mathrm{~cm} ; b=5 \mathrm{~mm} ; c=0.5 \mathrm{~mm}$. 
Varley crossroads on Southern Cross rd, Hill 3062, 1 Sep 1988 (NSW); cnr Kings rd \& Treloar rd, Hill 3004, 31 Aug 1988 (NSW); 4.6 km N of Beatty Rd on Stennets Lake Rd, Hill 3032, 1 Sep 1988 (NSW); $21.8 \mathrm{~km}$ from Kondinin towards Corrigin, Johnson 9096 \& Johnson, 16 May 1988 (NSW); 13.7 km S of Lake King (junction on Ravensthorpe Rd), Johnson 9184 \& Briggs, 1 Nov 1988 (NSW, CANB, PERTH); $17.3 \mathrm{~km}$ by road from Wellstead towards Boxwood Hill, on South Coast Highway, Powell 3280, Everett \& Bedford, 16 Nov 1985 (NSW, CANB, PERTH).

\section{Eucalyptus luculenta L.A.S. Johnson E K.D. Hill, sp. nov.}

Inter subserie Transcontinentali distinguitur: habitus 'malleeformis' (multicaulis); cortex laevis; folia alabastra et fructus magni, alabastra et fructus glauci sed lucentes sub pruinosi.

Type: Western Australia: $127.8 \mathrm{~km}$ south of Balladonia roadhouse on track to Mount Ragged, K.D. Hill 247 E L.A.S. Johnson, 20 Oct 1983 (holo NSW; iso PERTH).

Slender multistemmed mallee to $5 \mathrm{~m}$ tall. Bark smooth, grey-white and pink. Plant \pm glaucous. Juvenile leaves opposite for many nodes, elliptical, sessile and strongly decurrent, glaucous, to $5 \mathrm{~cm}$ long, $2.5 \mathrm{~cm}$ wide. Adult leaves disjunct, lanceolate to ovate, acute or acuminate, dull, $5.0-11.0 \mathrm{~cm}$ long, $1.5-3.5 \mathrm{~cm}$ wide; petioles terete or slightly flattened, $1.4-3.3 \mathrm{~cm}$ long; lateral veins at c. $45^{\circ}$ to midrib, regular, moderately spaced; secondary reticulum open, somewhat degenerate; intramarginal vein distinct, 1-3 mm from margin. Umbellasters axillary, 7-flowered; peduncles terete, often recurved, 7-14 mm long; pedicels terete, 2-6 mm long. Mature buds elongate ovoid, apically tapered and \pm rostrate, $13-17 \mathrm{~mm}$ long, 5-7 $\mathrm{mm}$ diam.; calyptra narrowly conical, flared at base, 2-3 times longer than hypanthium, wider than hypanthium. Stamens all fertile; anthers subglobular, \pm basifixed, versatile; connective gland large; cells divergent, dehiscing by short slits. Fruits cup-shaped to urceolate or cylindrical, highly glossy beneath a pruinose wax coating, apically constricted, 4-5-locular, 7-11 $\mathrm{mm}$ long, 6-10 mm diam.; calyptra scar and stemonophore \pm level, c. $0.5 \mathrm{~mm}$ wide; disc depressed at $40-60^{\circ}, 1-2 \mathrm{~mm}$ wide; valves deeply enclosed basally, acuminate tips vertically exserted, remnants of persistent style forming tips of valves. Seeds semi glossy, dark grey brown, rounded, finely and shallowly reticulate, $1.5 \mathrm{~mm}$ long; hilum ventral; chaff similar, smaller glossy pale brown (Fig. 19).

Distinguished by the combination of: mallee habit; smooth bark; large leaves, buds and fruits; glaucous buds and fruits.

A restricted species, although locally common, in rich mixed mallee communities, on sandy calcareous soil in the vicinity of Mt Ragged (Fig. 14). Associated species include E. discreta, E. oleosa, E. leptocalyx, E. tetragona and Melaleuca spp.

The epithet is from the Latin luculentus, full of light, splendid, referring to the pronounced glossiness of the fruits underneath the pruinose waxy coat.

Conservation status: not considered to be under immediate threat, although restricted in distribution (2R).

Selected specimens (from 7 examined): Western Australia: 30 miles [48 km] NE of Mt Ney coastal $\mathrm{nr}$ the Archipelago of the Recherche, Beard 6367, 16 Sep 1970 (KPBG, NSW); 98 miles [156.8 km] $\mathrm{E}$ of Esperance on the Fisheries road towards Balladonia, NE of T/O [turnoff] to Israelite Bay, Brooker B 4485, 9 Apr 1974 (CANB, NSW); 23.9 km from Fisheries Rd on track to Mt Ragged, Hill 3166, 8 Sep 1988 (NSW); Balladonia Track between Boyatup Hill and Mount Ragged 9.7 km southwest of Israelite Bay turnoff, Rodd 5155 \& Hardie, 24 Nov 1985 (NSW).

\section{Subseries Flocktonianosae}

Subseries defined as follows: juvenile leaves opposite, sessile, decurrent; adult leaves highly glossy; filaments usually regularly inflexed in bud, sometimes with a few outer filaments erect; style tip inserted into calyptra. 
A subseries of two species with a complicated overlapping distribution. Distribution is primarily through the eastern Wheatbelt and Goldfields of Western Australia, extending to the edges of the Great Victoria Desert, with an unusual disjunct occurrence in the Eyre Peninsula region of South Australia (discussed below).

28. Eucalyptus urna D. Nicolle, Austral. Syst. Bot. 12 [in press]

Type: Western Australia: $0.6 \mathrm{~km}$ along Old Ravensthorpe Road from Newdegate to Lake King Road, Brooker 10008, 21 July 1988 (holo PERTH, iso AD, CANB, NSW).

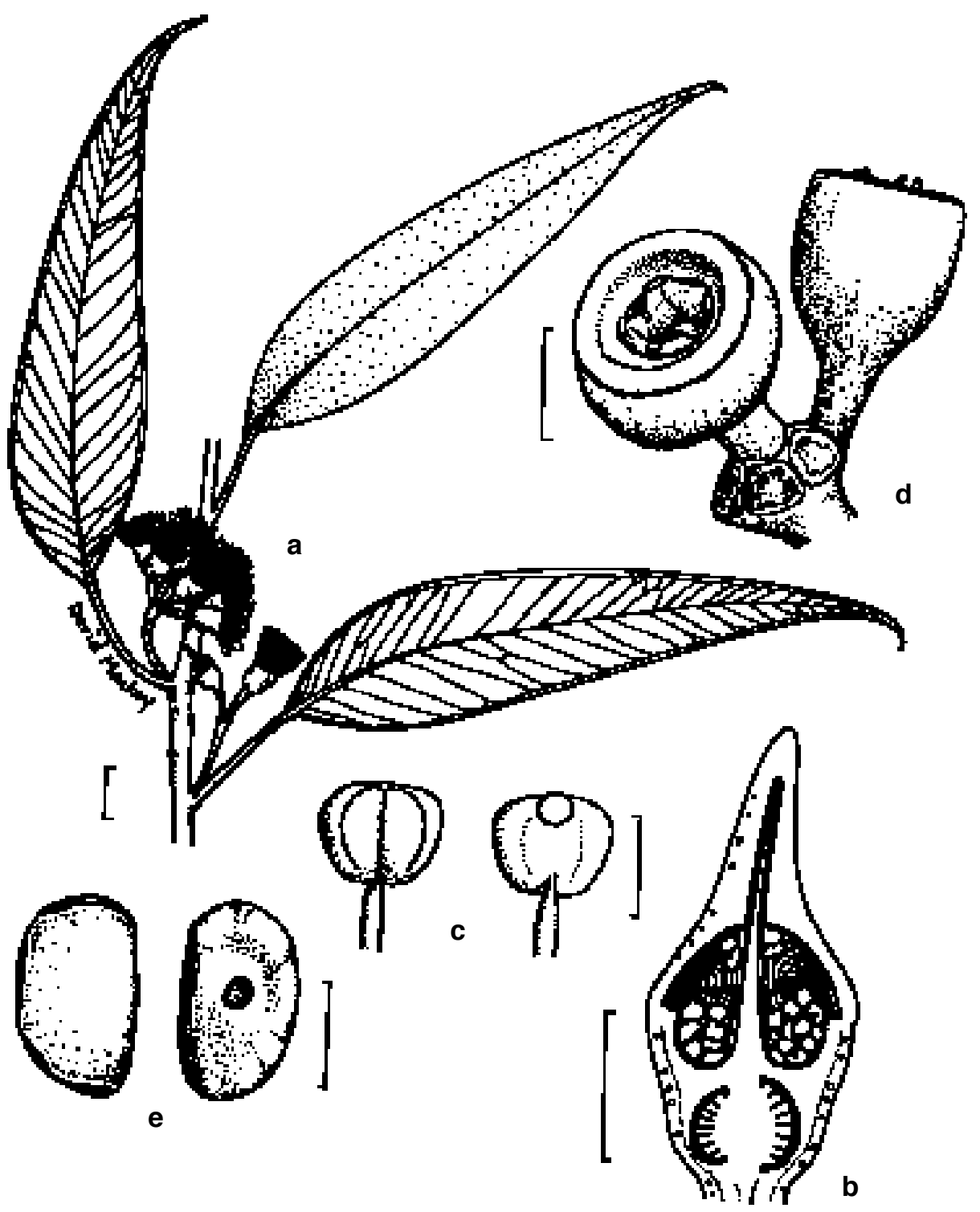

Fig. 19. E. luculenta. a, adult leaves, inflorescences, buds and flowers. $\mathbf{b}$, transverse section of bud. $\mathbf{c}$, anther. $\mathbf{d}$, inflorescence and fruits. e, seed (from Hill 247). Scale bar: $\mathrm{a}=1 \mathrm{~cm} ; \mathrm{b}, \mathrm{d}=5 \mathrm{~mm}$; $\mathrm{c}=0.5 \mathrm{~mm} ; \mathrm{e}=1 \mathrm{~mm}$. 
Tree ('marlock') to $20 \mathrm{~m}$ tall. Bark smooth, white, sometimes with pale yellow or orange patches, often highly glossy. Juvenile leaves opposite, sessile, ovate to elliptical, glaucous, apiculate, to $7 \mathrm{~cm}$ long, $3.5 \mathrm{~cm}$ wide; leaf margins crenate, strongly decurrent; juvenile stems 4-winged. Adult leaves disjunct, narrow-lanceolate to lanceolate, acute or acuminate, highly glossy, not glaucous, $5.0-16.0 \mathrm{~cm}$ long, $0.7-3.0 \mathrm{~cm}$ wide; petioles terete, $1.0-2.5 \mathrm{~cm}$ long; lateral veins obscure, to $30-45^{\circ}$ to midrib, moderately spaced; secondary reticulum indistinct; intramarginal vein distinct, $0.5-2 \mathrm{~mm}$ from margins. Umbellasters axillary, 7-flowered; peduncles terete, frequently deflexed, 9-18 mm long; pedicels terete, 7-15 mm long. Mature buds fusiform, rostrate, not glaucous, 15-24 mm long, 7-10 mm diam.; calyptra hemispherical, strongly rostrate for more than half length, 2-3 times longer than hypanthium; wider than hypanthium at base; hypanthium swollen, irregularly ribbed, sometimes strongly. Stamens all fertile; anthers subglobular, \pm basifixed, versatile; connective gland large; cells dehiscing by slits. Fruits urceolate and strongly swollen, 3-4-locular, 7-11 mm long, 7-12 mm diam.; hypanthium irregularly ribbed, sometimes strongly; calyptra scar flat, 0.5-1.0 $\mathrm{mm}$ wide; stemonophore flat, $0.5-1 \mathrm{~mm}$ wide; disc flat or slightly depressed, 1-3 mm wide; valves deeply enclosed basally, acuminate tips vertically exserted, remnants of persistent style forming tips of valves. Seeds semiglossy, dark grey-brown to redbrown, rounded, finely and shallowly reticulate, $1.5-2.0 \mathrm{~mm}$ long; chaff dull, redbrown, angular (Fig. 20).

Distinguished from E. flocktoniae by the tree habit and the ribbed, distinctly urceolate fruits. It has been wrongly regarded as 'true flocktoniae', leading to confusion in Western Australia and generally (e.g. Brooker \& Kleinig 1990).

Distributed through the Southern Goldfields region and east in Western Australia, from around Bullabulling south to Ravensthorpe, west to Kondinin and east almost to Caiguna Fig. 21). Occurrences in central Eyre Peninsula, South Australia, are morphologically intermediate between E. urna and E. flocktoniae, but cannot represent simple hybrids or swarms since neither of these species occurs in proximity, or even in South Australia (see E. peninsularis and Fig. 21). It is presumed that these occurrences represent an outlier of the stock from which the above taxa originated, but were not subjected to the same environmental influences and consequently did not show the same differentiation.

A widespread and often locally abundant species in open woodland on flat sites on calcareous loams A wide range of associated eucalypt species has been recorded, commonly including E. salmonophloia, E. celastroides and several different members of the E. transcontinentalis complex, with an open shrub understorey of Melaleuca spp. or Cratystylis.

Conservation status: not considered to be at risk.

Selected specimens (from 49 examined): Western Australia: 0.1 miles [0.2 km] (L) of well-used track, 9.7 miles [15.5 km] SE of Norseman, Baker 47, 11 Nov 1970 (CANB, NSW); $90 \mathrm{~km} \mathrm{E} \mathrm{of}$ Hyden, on Norseman Rd, Blaxell W 75/28 \& Brooker, 3 Oct 1975 (NSW); 20 km W of Bullabulling, Brooker 6396, 20 Aug 1979 (CANB, NSW, PERTH); $7.2 \mathrm{~km} \mathrm{~S}$ of Hyden to Norseman road on road $6 \mathrm{~km}$ W of Crossroads, Brooker 6303, 11 Aug 1979 (CANB, NSW, PERTH); 7.5 miles [12 km] E of Karalee, Chippendale 285, 13 Aug 1967 (CANB, NSW); 102.8 miles [164.5 km] SSE of Southern Cross, Chippendale 347, 348, 19 Mar 1968 (CANB, NSW); $44.9 \mathrm{~km} \mathrm{~W}$ of Caiguna on hwy 1, Hill $201 \mathcal{E}$ Johnson, 19 Oct 1983 (NSW, CANB, PERTH); $63.1 \mathrm{~km} \mathrm{~S}$ of Balladonia roadhouse on track to Mt Ragged, Hill $237 \mathcal{E}$ Johnson, 20 Oct 1983 (NSW, CANB, PERTH); $136 \mathrm{~km}$ E of Balladonia roadhouse on highway, Hill 2179 \& Johnson, 3 Nov 1986 (NSW, CANB, MEL, PERTH); $22.4 \mathrm{~km}$ from Newdegate to Lake King rd on Old Ravensthorpe Rd, Hill 3015, 31 Aug 1988 (NSW); 13.2 $\mathrm{km} \mathrm{N}$ of Beatty Rd on Stennets Lake Rd, Hill 3033, 1 Sep 1988 (NSW, CANB, PERTH); $7.8 \mathrm{~km}$ E of RPF [Rabbit Proof Fence] on Varley to Southern Cross rd, Hill 3055, 1 Sep 1988 (NSW); 15.0 km N of Israelite Bay t/o [turnoff] at Mt Ragged on track to Balladonia, Hill 3168, 8 Sep 1988 (NSW); 16 km SE of Ardler Rd on Old Ravensthorpe Rd, Johnson 9085 \& Johnson, 15 May 1988 (NSW). 
29. Eucalyptus flocktoniae (Maiden) Maiden, J. E Proc. Roy. Soc. New South Wales 49: 316 (1916).

Basionym: Eucalyptus oleosa F. Muell. ex Miq. var. flocktoniae Maiden, J. Western Australian Nat. Hist. Soc. 3: 172 (1911).

Type: Western Australia: Desmond, near Ravensthorpe, Western Australia, J.H. Maiden, 11.1909 (Lectotype: NSW, designated by Maiden, C.R. 2, Plate 69, Fig. 1. This specimen comprises 2 sheets, one of which is numbered NSW 83124). Maiden's original 1911 citation was 'Esperance, Lindley J. Cowan, January 1902. Desmond near Ravensthorpe, J.H. Maiden, November, 1909, apparently not abundant.'

Mallee to $7 \mathrm{~m}$ tall, rarely a small tree. Bark smooth, white to pale grey. Juvenile leaves opposite, sessile, ovate to elliptical, glaucous, apiculate, to $7 \mathrm{~cm}$ long, $3 \mathrm{~cm}$ wide; leaf margins crenate, strongly decurrent; juvenile stems 4-winged. Adult leaves disjunct, lanceolate, acute or acuminate, semi to highly glossy, not glaucous, $6.0-16.0$ $\mathrm{cm}$ long, $0.8-3.0 \mathrm{~cm}$ wide; petioles terete, $1.0-3.0 \mathrm{~cm}$ long; lateral veins obscure, to
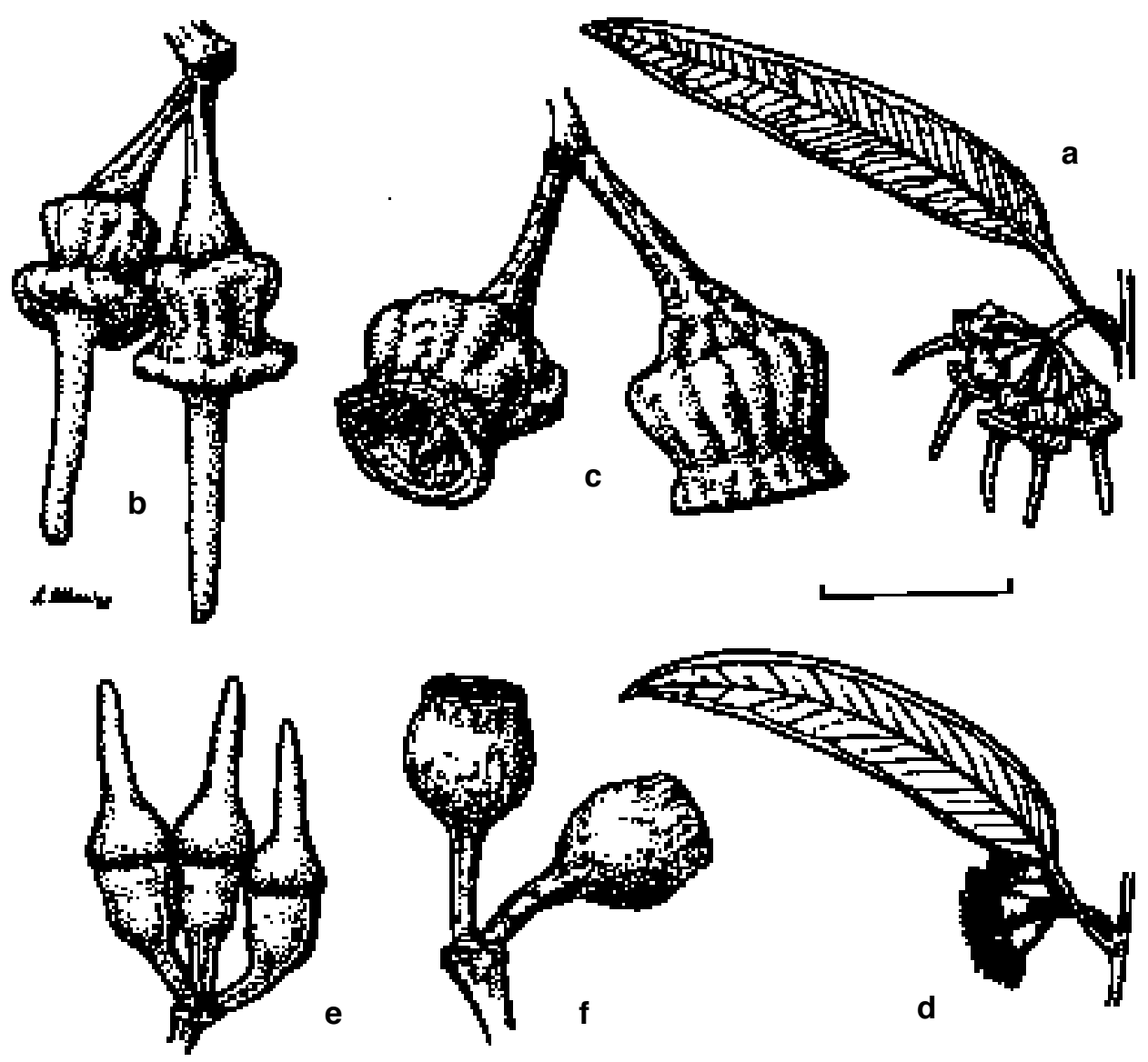

Fig. 20. E. urna. a, adult leaves, inflorescence and buds. b, inflorescence and buds. c, inflorescence and fruits (from Brooker 10008). E. flocktoniae subsp. hebes. d, adult leaves, inflorescence and buds. e, inflorescence and buds (from Hill 222). f, inflorescence and fruits (from Hill 2215). Scale bar: $a, d=3 \mathrm{~cm} ; b, c, e, f=1 \mathrm{~cm}$. 
$30-45^{\circ}$ to midrib, moderately spaced; secondary reticulum indistinct; intramarginal vein distinct, $0.5-2 \mathrm{~mm}$ from margins. Umbellasters axillary, 7-flowered; peduncles terete, frequently deflexed, 4-11 mm long; pedicels terete, 4-7 mm long. Mature buds fusiform, rostrate, sometimes slightly glaucous, 10-20 mm long, 4-6 mm diam.; calyptra hemispherical, strongly rostrate for more than half length, 1.5-2.5 times longer than hypanthium; sometimes wider than hypanthium at base; hypanthium smooth or vaguely ribbed. Stamens all fertile; anthers subglobular, \pm basifixed, versatile; connective gland large; cells dehiscing by slits. Fruits urceolate, ovoid or cup-shaped, 3-4-locular, 8-10 mm long, 7-8 mm diam.; hypanthium smooth to vaguely irregularly ribbed; calyptra scar flat, c. $0.5 \mathrm{~mm}$ wide; stemonophore flat, c. $0.5 \mathrm{~mm}$ wide; disc flat or slightly depressed, $1-3 \mathrm{~mm}$ wide; valves deeply enclosed basally, acuminate tips vertically exserted, remnants of persistent style forming tips of valves. Seeds semiglossy, dark grey-brown to red-brown, rounded, finely and shallowly reticulate, 1.5-2.0 mm long; chaff dull, red-brown, angular (Fig. 20).

Distinguished from E. urna by the mallee habit, broader leaves, shorter peduncles and pedicels, and smooth or less ribbed buds and fruits.

A widely distributed species, occurring mainly on yellow or orange sand over laterite from about Enneabba south to the Stirling Range, and east almost to Balladonia (Fig. 21). E. flocktoniae is a component of the rich and varied mallee shrublands of this region, with some 35 eucalypt species recorded as associates.

Two geographic subspecies are recognised.

New growth green; adult foliage green, highly glossy

29A. subsp. flocktoniae

New growth bluish; adult foliage bluish-green, not highly glossy 29B. subsp. hebes

\section{A. Eucalyptus flocktoniae subsp. flocktoniae}

Distinguished from subsp. hebes be the green, glossy adult foliage and new growth.

A widely distributed species, from about Eneabba south to the Stirling Range, and east to Ravensthorpe district (Fig. 21).

Locally abundant in low mallee scrub occurring mainly on yellow or orange sand over laterite on slight rises or higher sites sites. A wide range of asociated small mallee species has been recorded, with an open shrub understorey of mixed scleromorphic species.

Conservation status: not considered to be at risk.

Selected specimens (from 63 examined): Western Australia: $31 \mathrm{~km} \mathrm{~W}$ of Three Springs, W end of Nehru Rd at junction with Moorlaby Rd, Briggs 7518 \& Johnson, 30 Sep 1984 (NSW, PERTH); $20.4 \mathrm{~km} \mathrm{~S}$ of Jerramungup on South Coast Highway, Briggs 7834 E Johnson, 10 Oct 1984 (NSW, PERTH); $30 \mathrm{~km}$ from Tammin on York Rd, Brooker 7631, 15 Sep 1982 (CANB, NSW); $8.4 \mathrm{~km} \mathrm{~W}$ of Piawaning, Brooker 8500, 17 Mar 1984 (CANB, NSW); Babilion Range, N of Mogumber, Brooker 8525, 23 Apr 1984 (CANB, NSW); 14.9 km S of Dumbleyung towards Nyabing, Brooker 8777, 4 Jan 1985 (CANB, NSW); 4.5 km E of Boorabbin Rock, Brooker 9040, 12 Aug 1985 (CANB, NSW); Ravensthorpe Range, 1 km N of Mt Desmond, 10 km ESE of Ravensthorpe, Crisp 4973, 9 Jan 1979 (CANB, NSW, PERTH); Harrismith, Gardner 2107, 5 Mar 1924 (PERTH, NSW); Gnowangerup, Grasby, 23 Apr 1912 (NSW); 4 km N of Bremer Bay rd on track to Ongerup (turnoff $64 \mathrm{~km} \mathrm{~W}$ of Bremer Bay), Hill 348 Johnson \& Blaxell, 23 Oct 1983 (NSW, PERTH); $5 \mathrm{~km} \mathrm{~S}$ of Amelup on Chester Pass rd, Hill 354 Johnson \& Blaxell, 23 Oct 1983 (NSW, PERTH); $52.4 \mathrm{~km}$ E of Yellowdine on highway, Hill 2625 \& Johnson, 26 Nov 1986 (NSW, PERTH); Wongan Hills, N slope of Mt O'Brien on track to radio tower, Hill 2932, 27 Aug 1988 (NSW); $3.1 \mathrm{~km} \mathrm{~W}$ of Corrigin on Brookton rd, then $0.5 \mathrm{~km}$ to $\mathrm{S}$ on track to lookout, Hill 2981, 31 Aug 1988 (NSW, CANB, PERTH); $6.9 \mathrm{~km} \mathrm{~N}$ of Old Lake Grace rd on Wishbone rd, Hill 3000, 3001, 31 Aug 1988 (NSW, CANB, PERTH); $4.7 \mathrm{~km} \mathrm{~W}$ of Newdegate on Lake Grace rd, Hill 3010, 31 Aug 1988 (NSW, CANB, PERTH); c. 9.6 km SSW of New Norcia, Hopper 5842, 10 Dec 1986 (PERTH, CANB, MEL, NSW); Gardner Reserve 16 km S of 
Tammin along N boundary fence $0.3 \mathrm{~km}$ from W end, Johnson 9202 \& Briggs, 2 Nov 1988 (NSW, CANB); 0.75 mile [1.2 km] E of Manmanning, Avon Location 19400, Smith 1279, 17 Mar 1990 (MEL, AD, CANB, CANB, HO, NSW, PERTH, S); Tindale 3806, 29 Aug 1973 (NSW, DAR, PERTH); 61 miles $[97.6 \mathrm{~km}]$ from Esperance, towards Norseman.

29B. Eucalyptus flocktoniae subsp. hebes D. Nicolle, Austral. Syst. Bot. 12 [in press]

Type: Western Australia: $34.2 \mathrm{~km}$ from Balladonia roadhouse towards Norseman on Eyre Highway, D. Nicolle 1830, 6 Oct 1996 (holo PERTH, iso AD).

Distinguished from subsp. flocktoniae by the dull, bluish new growth, the dull to semiglossy bluish-green adult foliage, and the generally more robust habit.

Locally abundant in open mallee woodland on flat sites on calcareous loams in the south-eastern goldfields region, from Queen Victoria Rock east almost to Balladonia and south almost to the coast (Fig. 21). A wide range of associated eucalypt species has been recorded, commonly including E. eremophila, E. oleosa and E. urna, with an open shrub understorey of Melaleuca spp.

Conservation status: not considered to be at risk.

Selected specimens (from 16 examined): Western Australia: $3.5 \mathrm{~km} \mathrm{~S}$ of Tower Peak (Mt Ragged), Crisp 4849, 6 Jan 1979 (CANB, NSW, PERTH);c. 8 km N of Queen Victoria Rock, SW of Coolgardie, Brooker 9041, 9042, 13 Aug 1985 (CANB, NSW); $9.8 \mathrm{~km} \mathrm{~W}$ of Balladonia roadhouse on Hwy 1, Hill 208 \& Johnson, 19 Oct 1983 (NSW, CANB, PERTH);12.2 km along Howick rd, NW from Muntz rd crossing, E of Esperance, Hill 279, 280 \& Johnson, 21 Oct 1983 (NSW); $85.9 \mathrm{~km}$ E of Norseman on highway, Hill 2215 E Johnson, 4 Nov 1986 (NSW, CANB, MEL, PERTH); c. 5.4 miles [8.6 km] W of Jerdacuttup crossing on Ravensthorpe to Esperance Rd, Wrigley, 2 Nov 1968 (CANB, NSW).

\section{Eucalyptus peninsularis D. Nicolle, Austral. Syst. Bot. 12 [in press]}

Type: South Australia: 10.9 km from Karkoo towards Cummins, D. Nicolle 1953, 25 Oct 1996 (holo AD).

Mallee to $7 \mathrm{~m}$ tall. Bark smooth, white to pale grey, sometimes with darker patches, often glossy. Juvenile leaves opposite, sessile, ovate to elliptical, glaucous, apiculate, to $7.0 \mathrm{~cm}$ long, $3.5 \mathrm{~cm}$ wide; leaf margins crenate, strongly decurrent; juvenile stems 4-winged. Adult leaves disjunct, narrow-lanceolate to lanceolate, acute or acuminate, highly glossy, not glaucous, $6.0-13.0 \mathrm{~cm}$ long, $1.0-2.2 \mathrm{~cm}$ wide; petioles terete, $1.0-2.5$ $\mathrm{cm}$ long; lateral veins obscure, at $30-45^{\circ}$ to midrib, moderately spaced; secondary reticulum indistinct; intramarginal vein distinct, $0.5-2 \mathrm{~mm}$ from margins. Umbellasters axillary, 7-11-flowered; peduncles terete, frequently deflexed, 8-15 mm long; pedicels terete, 4-10 mm long. Mature buds fusiform, rostrate, not glaucous, $15-20 \mathrm{~mm}$ long, 5-7 mm diam.; calyptra hemispherical, strongly rostrate for more than half length, 2-3 times longer than hypanthium; wider than hypanthium at base; hypanthium swollen, irregularly ribbed, sometimes strongly. Stamens all fertile; anthers subglobular, \pm basifixed, versatile; connective gland large; cells dehiscing by slits. Fruits urceolate and strongly swollen, 3-4-locular, 9-11 mm long, 6-9 mm diam.; hypanthium irregularly ribbed, sometimes strongly; calyptra scar flat, $0.5-1.0 \mathrm{~mm}$ wide; stemonophore flat, $0.5-1 \mathrm{~mm}$ wide; disc flat or slightly depressed, $1-3 \mathrm{~mm}$ wide; valves deeply enclosed basally, acuminate tips vertically exserted, remnants of persistent style forming tips of valves. Seeds semiglossy, dark grey-brown, rounded, finely and shallowly reticulate, 1.5-2.0 mm long; chaff dull, red-brown, angular. (Fig. 20).

Distinguished from E. urna by the mallee habit, and from E. flocktoniae by the ribbed buds and fruits, the more distinctly glossy leaves and the more robust habit.

Distributed through southern Eyre Peninsula, South Australia. 


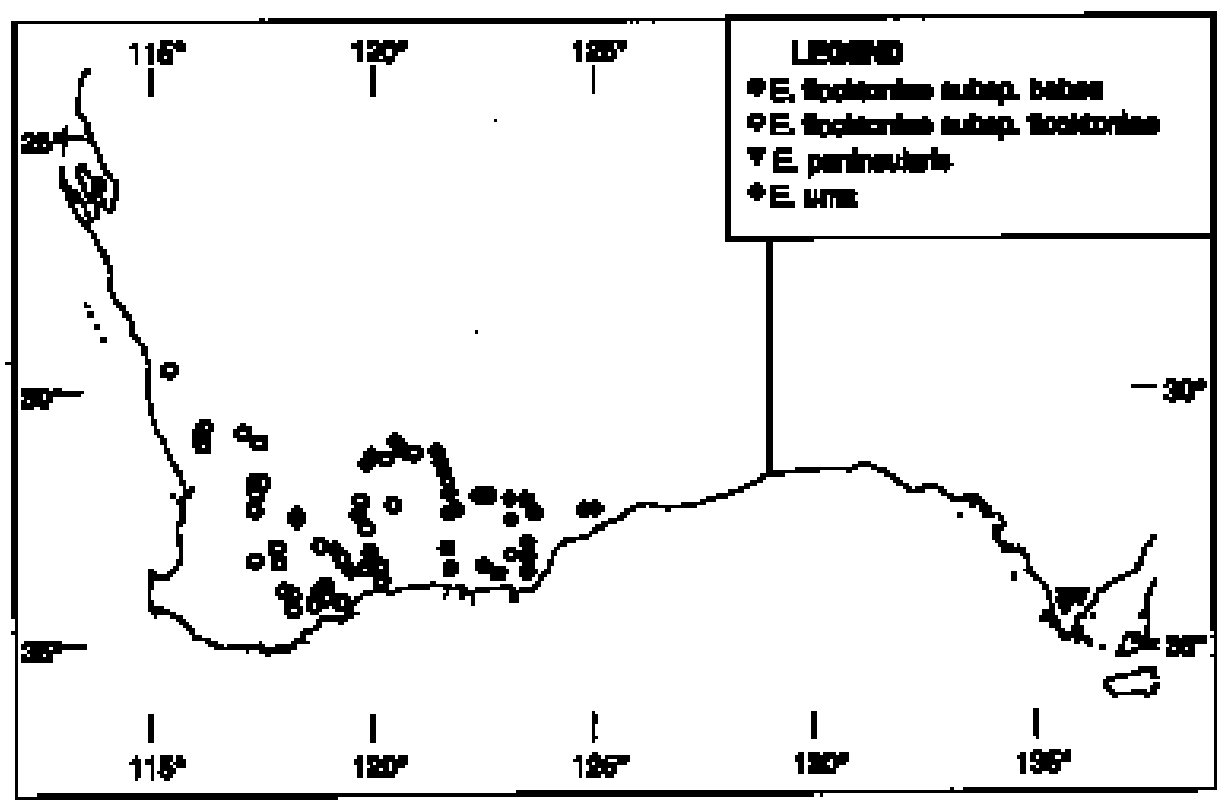

Fig. 21. Distribution of E. flocktoniae subsp. hebes, E. flocktoniae subsp. flocktoniae, E. urna and E. peninsularis

A restricted species in tall mallee woodland on flat sites on calcareous loams. A wide range of associated eucalypt species has been recorded, commonly including E. pileata, E. calycogona and E. leptophylla, with a shrub understorey of Melaleuca spp.

Conservation status: a restricted species in southern Eyre Peninsula. A conservation code of $3 \mathrm{R}$ is appropriate.

Selected specimens (from 4 examined): South Australia: 18 m [28.8 km] Karalee Royce 8580, 27 Mar 1969 (PERTH, NSW).

\section{Species of putative interserial hybridogenous origin}

\section{Series Falcatosociales}

The possibly hybrid origin of this species is discussed below. With such relationships, it cannot logically be placed in either series Falcatae or series Sociales, and and intermediate 'series of convenience' is required. The series is defined by its single constituent species.

\section{Eucalyptus intrasilvatica L.A.S. Johnson \& K.D. Hill, sp. nov.}

$\mathrm{Ab}$ E. aspera distinguitur: cortex toto laevis, folia juveniliter petiolata et fructus globosi. Characteres inter eas E. asperae et E. falcatae.

Type: Western Australia: $1.5 \mathrm{~km}$ south of Pikes Road on south Metro Road, Hill 2526 Johnson E Blaxell, 17 Nov 1986 (holo NSW; iso PERTH).

Mallee to $6 \mathrm{~m}$ tall. Bark smooth, grey and pale grey-brown. Juvenile leaves opposite, long-petiolate, ovate, to $5 \mathrm{~cm}$ long, $3 \mathrm{~cm}$ wide, becoming disjunct and broadlanceoltae. Adult leaves disjunct, lanceolate to broad-lanceolate, acute or acuminate, slightly glossy, $5.0-10.0 \mathrm{~cm}$ long, $0.8-2.5 \mathrm{~cm}$ wide; petioles terete or slightly flattened, 1.0-1.8 cm long; lateral veins at c. $45^{\circ}$ to midrib, obscure, regular, moderately spaced; 
secondary reticulum open, somewhat degenerate; intramarginal vein obscure, $0.5-1$ $\mathrm{mm}$ from margin. Umbellasters axillary, 7-15-flowered; peduncles terete, 4-10 $\mathrm{mm}$ long; pedicels terete, $2-5 \mathrm{~mm}$ long. Mature buds ovoid, apically tapered and strongly rostrate, $10-12 \mathrm{~mm}$ long, 4-5 $\mathrm{mm}$ diam.; calyptra narrowly conical, flared at base, 2-3 times longer than hypanthium, as wide as hypanthium or slightly narrower. Stamens all fertile; anthers subglobular, \pm basifixed, versatile; connective gland large; cells divergent, dehiscing by short slits. Fruits ovoid, apically contracted, 3-locular, 5-7 mm long, 5-8 mm diam.; calyptra scar level, c. $0.5 \mathrm{~mm}$ wide; stemonophore vertically raised and separated from hypanthium, c. $0.5 \mathrm{~mm}$ wide; disc \pm vertically depressed, 1-1.5 mm wide; valves deeply enclosed basally, acuminate tips vertically exserted, remnants of persistent style forming tips of valves. Seeds semi glossy, dark grey brown, rounded, finely and shallowly reticulate, $1.0-1.5 \mathrm{~mm}$ long; hilum ventral; chaff similar, smaller glossy pale brown. (Fig. 22).

Distinguished from E. aspersa by the wholly smooth bark, the ovate, petiolate juvenile leaves and the globose fruits. E. intrasilvatica is morphologically intermediate in juvenile leaf, bud and fruit characters between E. aspersa and E. falcata, and it seems highly likely that it originated as a hybrid between these taxa, both of which occur in the general vicinity. Several stands of E. intrasilvatica are known, and it would appear to be established and self-sustaining. Leaf morphology separates it from E. falcata, in that it lacks the gloss, the close lateral venation and the dense reticulation of the latter.

Known from a few small stands in the Darling Range near North Bannister (Fig. 23).

An extremely restricted species, occurring as small dense almost pure stands on locally shallower soils or sites of slightly impeded drainage over massive laterite in areas of otherwise uniform Jarah forest.

The epithet is from the Latin silvaticus, pertaining to woods, with the Latin prefix intra-, within, in reference to the occurrence within the Jarrah forest.

Conservation status: a rare and localised species, requiring close monitoring and further study of genetic diversity to assess its affinities fully.

Specimens examined: Western Australia: Metro road, $1.6 \mathrm{~km} \mathrm{~S}$ of Pikes road, $7.9 \mathrm{~km} \mathrm{~N}$ of Wearne road, North Bannister, Brooker 9043, 9 Oct 1985 (CANB, NSW); $0.6 \mathrm{~km} \mathrm{~S} \mathrm{of} \mathrm{Pikes} \mathrm{road,} \mathrm{Brooker} \mathrm{9044,}$ 9 Oct 1985 (CANB, NSW).

\section{Hybrids and intergrades}

E. canescens $\leftrightarrow$ E. vokesensis

= Eucalyptus yumbarrana Boomsma subsp. striata Boomsma, J. Adelaide Bot. Gard. 2(3): 298, fig. 3 (1980).

Type: South Australia: $50 \mathrm{~km}$ south-west of Lake Wyola, T. Dennis 182, 16 Aug 1979 (holo AD; iso AD, NSW).

E. eremicola $\leftrightarrow$ E. sublucida

Selected specimens (from 5 examined): South Australia: Great Victoria Desert, Connie Sue Highway, 6 km W of Vokes Hill corner, Symon 12434, 22 Aug 1980 (AD, CANB, NSW).

E. flocktoniae $\leftrightarrow$ E. urna

Specimens examined: Western Australia: $2.5 \mathrm{~km} \mathrm{NE}$ of Aerodrome Rd on Long Creek Rd, Hill 3024, 1 Sep 1988 (NSW).

E. flocktoniae $\times$ E. longicornis

Specimens examined: Western Australia: near Wagin, Gardner 1235, 9 Feb 1922 (PERTH, NSW).

E. flocktoniae $\times$ E. oleosa subsp. oleosa 


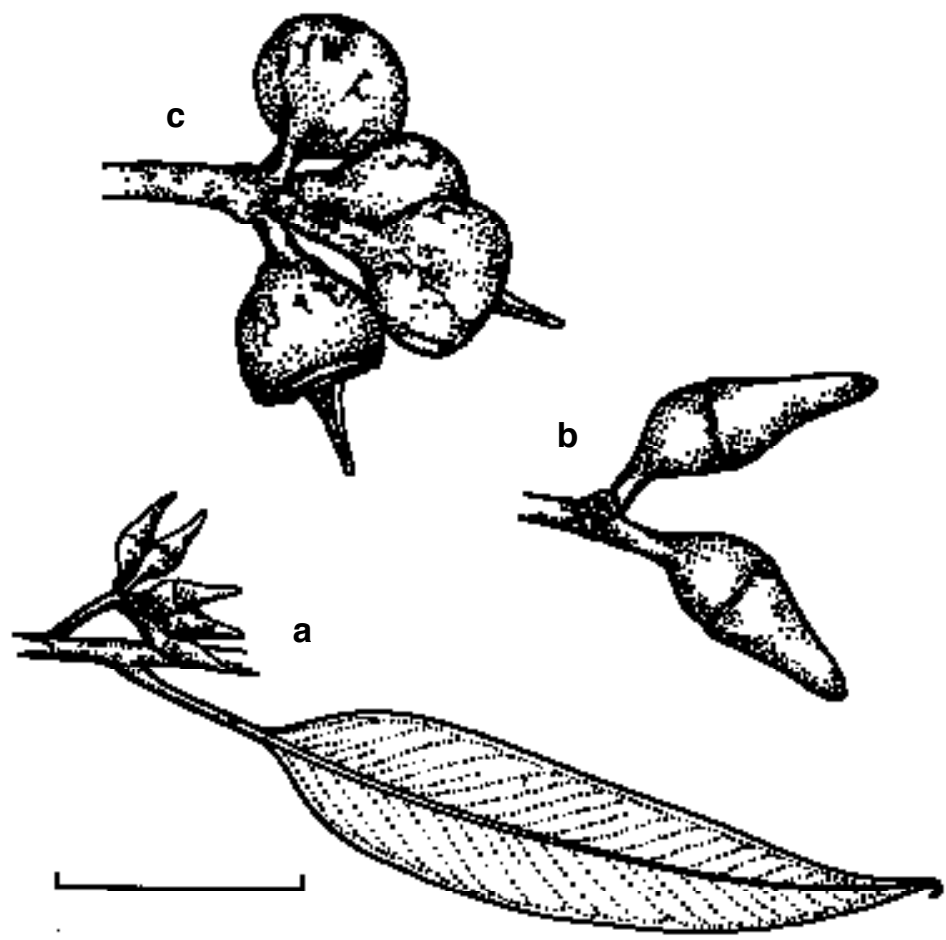

Fig. 22. E. intrasilvatica. a, adult leaves, inflorescence and buds. $\mathbf{b}$, inflorescence and buds. c, inflorescence and fruits (from Johnson 2526). Scale bar: $\mathrm{a}=3 \mathrm{~cm} ; \mathrm{b}, \mathrm{c}=1 \mathrm{~cm}$.

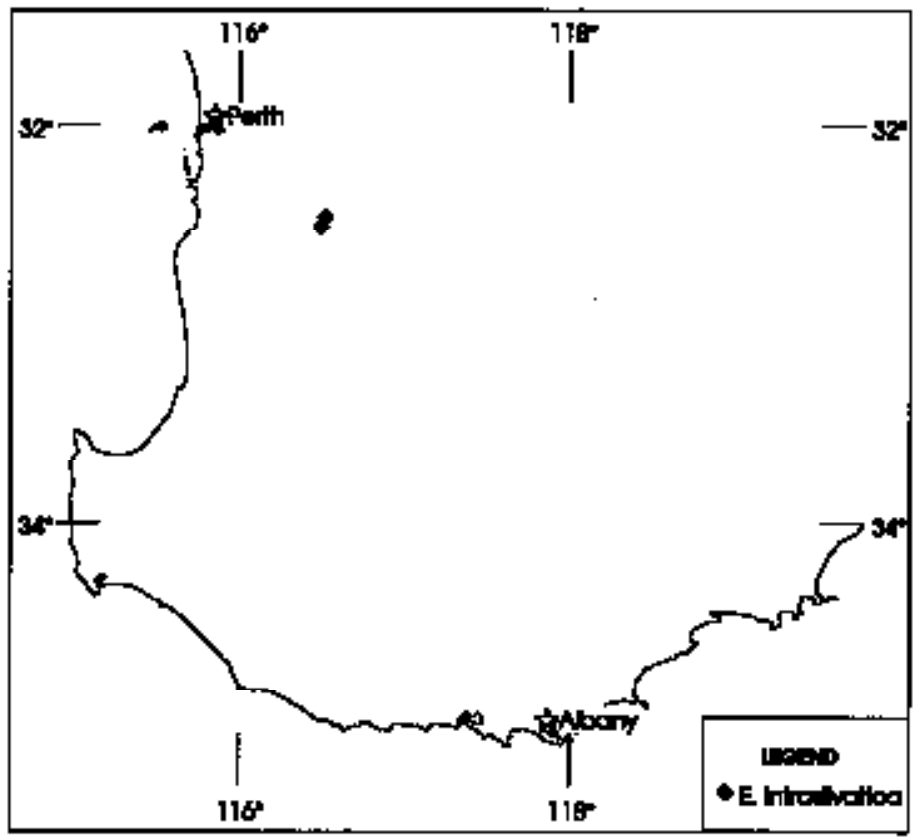

Fig. 23. Distribution of E. intrasilvatica. 
Specimens examined: Western Australia: 150 mile [240 km] peg Rabbit Proof Fence, Ralph $\mathcal{E}$ Stamford, June 1924 (NSW).

E. grasbyi $\times$ E. urna

Specimens examined: Western Australia: 0.2 miles [0.3 km] S of Widgiemooltha, Chippendale 144, 11 Mar 1967 (CANB, NSW).

E. longicornis-E. oleosa subsp. repleta

Selected specimens (from 4 examined): Western Australia: $19.6 \mathrm{~km} \mathrm{SE}$ of Coolgardie, Brooker 7042, 7044, 9 Nov 1981 (CANB, NSW, PERTH); 9.1 miles [14.6 km] S of Norseman, Chippendale 165, 13 Mar 1967 (CANB, NSW).

E. oleosa subsp. oleosa $\times$ E. socialis

Selected specimens (from 25 examined): New South Wales: South Far Western Plains: $34 \mathrm{~km}$ W of Balranald on Sturt Hway, Brickhill 10, 18 June 1986 (NSWF, NSW); Tarawi, 110 km NW of Wentworth, Brickhill 15, 29 Aug 1984 (NSW); Euston, Brownscombe s.n., Aug 1901 (NSW); 8.5 km east of Dareton, Sturt Highway, Fox 7905088, 27 May 1979 (NSW); 17 km W of Bidura Homestead, Fox 7910019, 5 Oct 1979 (NSW); 13 km SW of Nagaella homestead, Fox 7910073, 7 Oct 1979 (NSW); 9 km N of Nanya homestead, Fox 7910080, 7 Oct 1979 (NSW); Callitris Ridge, NW of Mungo homestead, Fox 8310461 \& Fallding, 20 Oct 1983 (NSW); 2 km S of boundary of Mungo National Park, on road to Wentworth and Mildura, Fox 8402145, 19 Feb 1984 (NSW); Tapalin, W of Euston, Noble, 5 May 1977 (NSW); Mindook Station, Euston, Noble \& Bawden, Aug 1979 (NSW); 4.5 km $\mathrm{N}$ of Buronga to Dareton road on Arumpo road, Wilson 3264, 4 Dec 1980 (NSW). South Western Plains: Moulamein to Balranald Rd, 5 miles [8 km] W of Moulamein Moore 3405, 18 July 1961 (CANB, NSW).

South Australia: Spring Dam, via Yunta, Brooker 2812, 4 Sep 1970 (CANB, NSW); River Murray, 12 m [19.2 km] E of Morgan, Cleland, 30 Nov 1913 (NSW); Pinnaroo, Gill, Oct 1907 (NSW); Calperum Station, ca. 12 km NE of Berri, Jackson 2644, 31 Mar 1975 (AD, NSW); Murray Desert, Mueller B, 1853 (NSW); $7 \mathrm{~km}$ east of 'Turlee' on the Balranald Road, south of Lake Mungo (Pooncarie survey site POO063), Porteners 9409009 \& Ashby, 17 Sep 1994 (NSW); c. 6 m [9.6 km] from Blanchetown bridge on road to Notts Well, just inside entrance to Breezy Estate, Symon 3173, 29 Dec 1964 (AD, NSW).

Victoria: Bumbang (near Euston), Blackburne L, 15 Sep 1908 (NSW).

E. oleosa subsp. oleosa $\times$ E. yalatensis

Specimens examined: South Australia: $57 \mathrm{~km}$ SE of Streaky Bay towards Pt Kenny, Brooker 7446, 25 Apr 1982 (CANB, NSW).

E. oleosa subsp. repleta $\times$ E. optima

Specimens examined: Western Australia: $16.9 \mathrm{~km} \mathrm{~W}$ of Balladonia roadhouse on highway, Hill 2190 \& Johnson, 4 Nov 1986 (NSW, CANB, MEL, PERTH).

E. oleosa subsp. repleta $\times$ E. transcontinentalis

Specimens examined: Western Australia: Coolgardie Goldfields, Pritzel 916, Nov 1901 (NSW, NSW).

E. oleosa subsp. repleta $\times$ E. yumbarrana

Specimens examined: South Australia: ca $30 \mathrm{~km}$ WNW of Ceduna, $1 \mathrm{~km} \mathrm{~N}$ of Koonibba Hill, Crisp 4747, 3 Jan 1979 (CANB, NSW).

E. oleosa subsp. victima $\times$ E. socialis

Specimens examined: South Australia: N of Gawler, near Roseworthy, Blake 20444, 23 Aug 1958 (BRI, AD, CANB, K, MO, NSW).

E. oleosa subsp. wylieana $\times$ E. urna

Specimens examined: Western Australia: 44.9 km W of Caiguna on Hwy 1, Hill 200 \& Johnson, 19 Oct 1983 (NSW).

E. oleosa subsp. wylieana $\times$ E. yalatensis 
Selected specimens (from 6 examined): South Australia: $52 \mathrm{~km} \mathrm{~W}$ of WA/SW border on Highway 1, Brooker 5621, 2 Apr 1977 (CANB, AD, MEL, NSW, PERTH); 99 km E of WA border, Brooker 8471, 10 Mar 1984 (CANB, NSW); 30.4 km W of Nullarbor, Brooker 9413, 27 Aug 1986 (CANB, NSW); $1.8 \mathrm{~km} \mathrm{~N}$ of Hwy 1 on track, t/off $152.5 \mathrm{~km} \mathrm{~W}$ of Nullarbor roadhouse, Hill 180, $181 \mathcal{E}$ Johnson, 18 Oct 1983 (NSW, CANB, PERTH); Nullarbor Plain, Yalata, ca. 10 km north-west of Fowlers Bay, Probert, May 1974 (AD, NSW).

E. peeneri $\leftrightarrow$ E. sublucida

Selected specimens (from 3 examined): Western Australia: $32 \mathrm{~km}$ E of Mooloogool [Homestead], Brooker 8330, 2 Nov 1983 (CANB, NSW).

\section{Acknowledgments}

Our colleague in the overall project, Don Blaxell, has contributed helpful discussions and has been involved in the recognition of several of the taxa. Thanks are also due to David Mackay, Nicola Oram and Lesley Elkan, who prepared the illustrations and especially to Leonie Stanberg, who has provided valuable technical and editorial assistance \& prepared the maps. Dean Nicolle is thanked for his insights on the typification of E. yumbarrana subsp. striata, and for access to his manuscript on the E. flocktoniae group.

\section{References}

Bentham, G. (1867) Flora Australiensis, vol. 3 (L. Reeve: London).

Blakely, W.F. (1934) A Key to the Eucalypts (Workers Press: Sydney).

Briggs, J.D. \& Leigh, J.H. (1996) Rare or Threatened Australian Plants. Australian National Parks and Wildlife Service, Special Publication 14.

Burbidge, N.T. (1947) Key to the South Australian species of Eucalyptus. Trans. Roy. Soc. South Australia 1: 137-163.

Chippendale, G.M. (1973) Eucalypts of the Western Australian Goldfields and the adjacent Wheatbelt (AGPS: Canberra).

Chippendale, G.M. (1988) Eucalyptus. In George, A.S. (ed.), Flora of Australia, vol. 19 (AGPS: Canberra).

Brooker, M.I.H. \& Kleinig, D.A. (1990) Field guide to eucalypts, vol. 2. South-western and southern Australia (Inkata Press: Chatswood).

Gardner, C.A. (1931) Enumeration Plantarum Australiae Occidentalis (Govt. Printer: Perth).

Gardner, C.A. \& Watson, E.M. (1950) The Western Australian varieties of Eucalyptus oleosa Muell. ex Miq. and their essential oils. J. \& Proc. Roy. Soc. Western Australia 34: 73-86.

Greuter, W. (ed.) (1994) International Code of Botanical Nomenclature ('Tokyo Code') (Koeltz: Königstein).

Hill, K.D. (1989) Botany and Biogeography of the Mallee Eucalypts, in Noble, J.C. \& Bradstock, R.A. (eds), Mediterranean landscapes in Australia: Mallee ecosystems and their management (CSIRO: Melbourne).

Hill, K.D. (1990) Biogeography of the mallee eucalypts, in Noble, J.C., Ross, P.J. \& Jones, G.K. (eds), The Mallee Lands: A conservation perspective (CSIRO: Melbourne).

Hill, K.D. \& Johnson, L.A.S. (1995) Systematic studies in the eucalypts. 7. A revision of the bloodwoods, genus Corymbia (Myrtaceae). Telopea 6:185-504.

Maiden, J.H. (1903-1933) A Critical Revision of the Genus Eucalyptus (Govt. Printer: Sydney).

Miquel, F.A.W. (1856) Stirpes Novo-Hollandas a Ferd. Muellero collectas. Ned. Kruidk. Arch. 4: 97-150.

Mueller, F. (1879) Eucalyptographia, preface.

Pryor, L.D. \& Johnson, L.A.S. (1971) A Classification of the Eucalypts (ANU Press: Canberra). 